\title{
Numerical Simulation of the Groundwater-Flow System in Tributary Subbasins and Vicinity, Lower Skagit River Basin, Skagit and Snohomish Counties, Washington
}

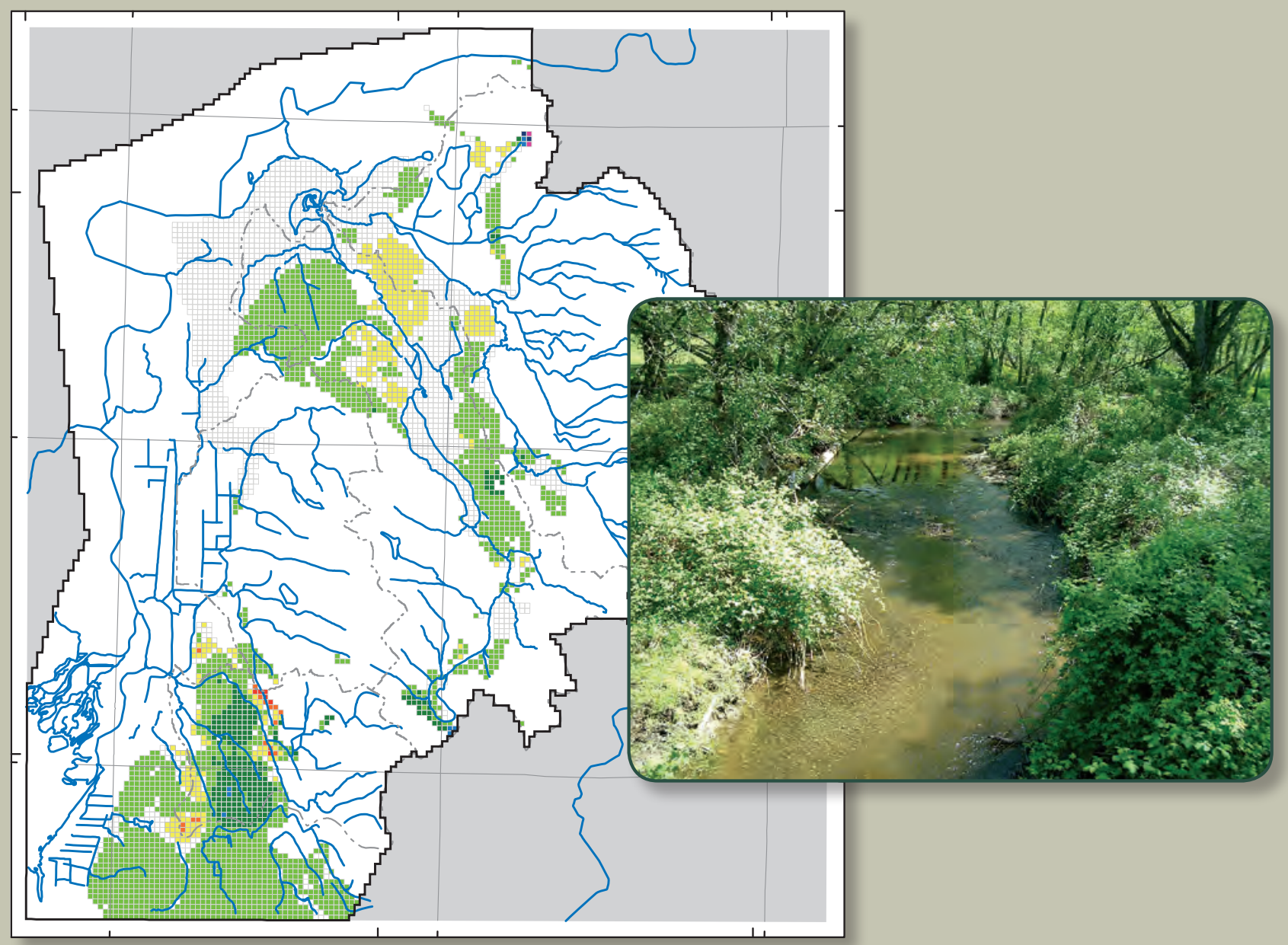

Scientific Investigations Report 2010-5184

Version 1.1, March 2011 
Cover:

Map of model simulation results for the lower Skagit River basin, Washington.

Photograph: Lake Creek which connects Lake McMurray to Big Lake, lower Skagit River basin, Washington. Photograph taken May 9, 2006, courtesy of Skagit County Public Works. 


\section{Numerical Simulation of the Groundwater-Flow System in Tributary Subbasins and Vicinity, Lower Skagit River Basin, Skagit and Snohomish Counties, Washington}

By Kenneth H. Johnson and Mark E. Savoca

Prepared in cooperation with the Skagit County Public Works Department and the Washington State Department of Ecology and Skagit County Public Utility District No. 1

Scientific Investigations Report 2010-5184

Version 1.1, March 2011 


\title{
U.S. Department of the Interior \\ KEN SALAZAR, Secretary \\ U.S. Geological Survey \\ Marcia K. McNutt, Director
}

\author{
U.S. Geological Survey, Reston, Virginia: 2010 \\ Revised: 2011
}

\begin{abstract}
For more information on the USGS - the Federal source for science about the Earth, its natural and living resources, natural hazards, and the environment, visit http://www.usgs.gov or call 1-888-ASK-USGS

For an overview of USGS information products, including maps, imagery, and publications, visit http://www.usgs.gov/pubprod

To order this and other USGS information products, visit http://store.usgs.gov
\end{abstract}

Any use of trade, product, or firm names is for descriptive purposes only and does not imply endorsement by the U.S. Government.

Although this report is in the public domain, permission must be secured from the individual copyright owners to reproduce any copyrighted materials contained within this report.

Suggested citation:

Johnson, K.H., and Savoca, M.E., 2010, Numerical simulation of the groundwater-flow system in tributary subbasins and vicinity, lower Skagit River basin, Skagit and Snohomish Counties, Washington: U.S. Geological Survey Scientific Investigations Report 2010-5184, 78 p. 


\section{Contents}

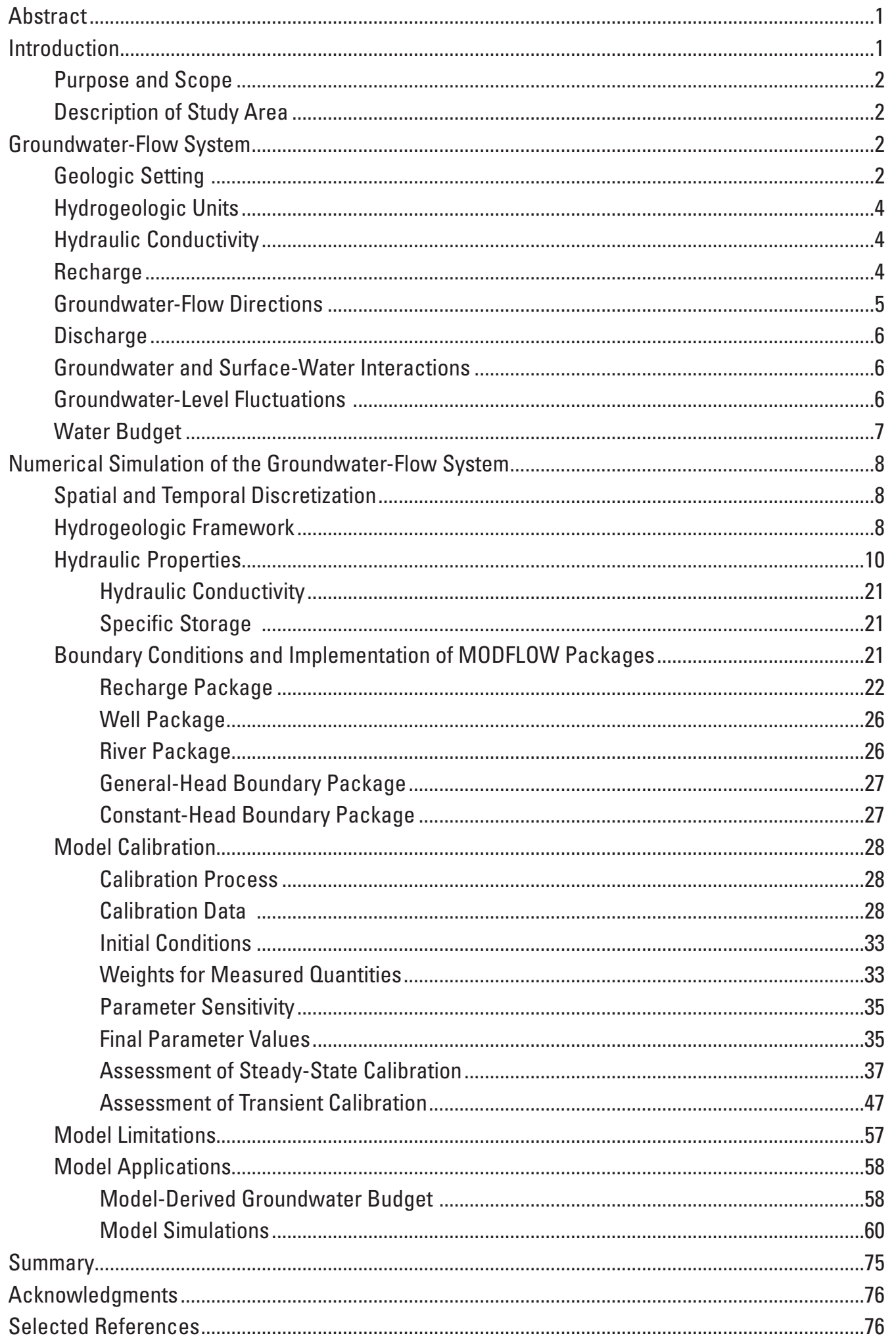




\section{Figures}

Figure 1. Map showing location of tributary subbasins and vicinity, lower Skagit River basin, Washington

Figure 2. Map showing locations of model river, general head, and constant-head cells, domestic and public supply wells, and irrigation wells, tributary subbasins and vicinity, lower Skagit River basin, Washington

Figure 3. Maps showing extent and thickness of hydrogeologic units simulated with the Hydrogeologic-Unit Flow package, tributary subbasins and vicinity, lower Skagit River basin, Washington

Figure 4. Vertical section showing relation of hydrogeologic and HUF units to numerical model layers, tributary subbasins and vicinity, lower Skagit River basin, Washington

Figure 5. Map showing distribution of average annual total groundwater recharge from precipitation and return flow in tributary subbasins and vicinity, lower Skagit

River basin, Washington, September 2006-September 2008

Figure 6. Map showing distribution of average annual groundwater recharge from return flow (septic and outdoor use) in tributary subbasins and vicinity, lower Skagit River basin, Washington, September 2006-September 2008

Figure 7. Graphs showing temporal discretization of selected model values, tributary subbasins and vicinity, lower Skagit River basin, Washington, September 2006-September 2008

Figure 8. Map showing locations of wells used in model calibration, tributary subbasins and vicinity, lower Skagit River basin, Washington

Figure 9. Graph showing sensitivity of the transient model calibration to changes in parameter values, tributary subbasins and vicinity, lower Skagit River basin, Washington

Figure 10. Graph showing simulated and measured water-level altitudes by HUF unit for the calibrated steady-state model, tributary subbasins and vicinity, lower Skagit River basin, Washington

Figure 11. Maps showing simulated water-level altitudes and residuals for the calibrated steady-state model, tributary subbasins and vicinity, lower Skagit River basin, Washington

Figure 12. Graph showing simulated and measured streamflows for the calibrated steady-state model, tributary subbasins and vicinity, lower Skagit River basin, Washington

Figure 13. Graph showing average simulated and measured water-level altitudes by HUF unit for the calibrated transient model, tributary subbasins and vicinity, lower Skagit River basin, Washington 


\section{Figures-Continued}

Figure 14. Hydrographs showing simulated and measured groundwater levels, tributary subbasins and vicinity, lower Skagit River basin, Washington, September 2006-September 2008

Figure 15. Graph showing simulated and measured stream baseflows for East Fork Nookachamps, Nookachamps, Carpenter, and Fisher Creeks, lower Skagit River basin, Washington, August 2007 and June 2008

Figure 16. Map showing simulated groundwater-level altitude change between the steady-state "base simulation" and simulation 1, tributary subbasins and vicinity, lower Skagit River basin, Washington

Figure 17. Map showing simulated groundwater-level altitude change between the steady-state "base simulation" and simulation 2, tributary subbasins and vicinity, lower Skagit River basin, Washington

Figure 18. Map showing simulated groundwater-level altitude change between the steady-state "base simulation" and simulation 3, tributary subbasins and vicinity, lower Skagit River basin, Washington

Figure 19. Map showing simulated groundwater-level altitude change between the steady-state "base simulation" and simulation 4, tributary subbasins and vicinity, lower Skagit River basin, Washington

Figure 20. Map showing simulated groundwater-level altitude change between the steady-state "base simulation" and simulation 5, tributary subbasins and vicinity, lower Skagit River basin, Washington

Figure 21. Map showing simulated groundwater-level altitude change between the steady-state "base simulation" and simulation 6, tributary subbasins and vicinity, lower Skagit River basin, Washington

Figure 22. Hydrographs showing simulated groundwater levels for transient "base simulation" and simulation 7 and difference, tributary subbasins and vicinity, lower Skagit River basin, Washington

Figure 23. Hydrographs showing simulated groundwater levels for transient "base simulation" and simulation 8 and difference, tributary subbasins and vicinity, lower Skagit River basin, Washington

Figure 24. Hydrographs showing simulated groundwater levels for transient "base simulation" and simulation 9 and difference, tributary subbasins and vicinity, lower Skagit River basin, Washington 


\section{Tables}

Table 1. Lithologic and hydrologic characteristics of hydrogeologic units, tributary subbasins and vicinity, lower Skagit River basin, Washington

Table 2. Estimated average annual water budget for tributary subbasins, lower Skagit River basin, Washington, September 1, 2006 to August 31, 2008

Table 3. Initial hydraulic property values of HUF units used in the steady-state model, tributary subbasins and vicinity, lower Skagit River basin, Washington $\ldots \ldots \ldots \ldots 10$

Table 4. Wells used in model calibration, tributary subbasins and vicinity, lower Skagit River basin, Washington

Table 5. Final hydraulic property values of HUF units used in the steady-state and transient model, tributary subbasins and vicinity, lower Skagit River basin, Washington 37

Table 6. Calibration statistics for steady-state target water levels by HUF unit, tributary subbasins, lower Skagit River basin, Washington.

Table 7. Calibration statistics for steady-state target water levels by tributary basin, lower Skagit River basin, Washington 38

Table 8. Calibration statistics for transient target water levels by HUF unit, tributary subbasins, lower Skagit River basin, Washington .

Table 9. Calibration statistics for transient target water levels by HUF unit, tributary subbasins, lower Skagit River basin, Washington....

Table 10. Model-derived groundwater flow, tributary subbasins and vicinity, lower Skagit River basin, Washington

Table 11. Comparison of selected water budget components for the "base simulation" steady-state condition and simulations 1 and 2, Nookachamps subbasin, lower Skagit River basin, Washington

Table 12. Comparison of selected water budget components for the "base simulation" steady-state condition and simulations 3 and 4, tributary subbasins, lower Skagit River basin, Washington

Table 13. Comparison of selected water budget components for the "base simulation" steady-state condition and simulations 5 and 6 , tributary subbasins, lower Skagit River basin, Washington

Table 14. Comparison of selected water budget components for the simulation period (October 2006 to September 2008) for the "base simulation" transient model and simulations 7 and 8, tributary subbasins, lower Skagit River basin, Washington

Table 15. Comparison of selected water budget components for the "base simulation" transient model and simulation 9, tributary subbasins, lower Skagit River basin, Washington 


\section{Conversion Factors, Datums, Abbreviations, and Acronyms}

\section{Conversion Factors}

Inch/Pound to SI

\begin{tabular}{|c|c|c|}
\hline Multiply & By & To obtain \\
\hline \multicolumn{3}{|c|}{ Length } \\
\hline inch (in.) & 2.54 & centimeter $(\mathrm{cm})$ \\
\hline inch (in.) & 25.4 & millimeter (mm) \\
\hline foot $(\mathrm{ft})$ & 0.3048 & meter (m) \\
\hline mile (mi) & 1.609 & kilometer (km) \\
\hline \multicolumn{3}{|c|}{ Area } \\
\hline acre & 4,047 & square meter $\left(\mathrm{m}^{2}\right)$ \\
\hline acre & 0.004047 & square kilometer $\left(\mathrm{km}^{2}\right)$ \\
\hline square foot $\left(\mathrm{ft}^{2}\right)$ & 0.09290 & square meter $\left(\mathrm{m}^{2}\right)$ \\
\hline section (640 acres or 1 square mile) & 259.0 & square hectometer $\left(\mathrm{hm}^{2}\right)$ \\
\hline square mile $\left(\mathrm{mi}^{2}\right)$ & 2.590 & square kilometer $\left(\mathrm{km}^{2}\right)$ \\
\hline \multicolumn{3}{|c|}{ Volume } \\
\hline acre-foot (acre-ft) & 1,233 & cubic meter $\left(\mathrm{m}^{3}\right)$ \\
\hline \multicolumn{3}{|c|}{ Flow rate } \\
\hline acre-foot per year (acre-ft/yr) & 1,233 & cubic meter per year (m³/yr) \\
\hline foot per day (ft/d) & 0.3048 & meter per day $(\mathrm{m} / \mathrm{d})$ \\
\hline cubic foot per second $\left(\mathrm{ft}^{3} / \mathrm{s}\right)$ & 0.02832 & cubic meter per second $\left(\mathrm{m}^{3} / \mathrm{s}\right)$ \\
\hline gallon per day (gal/d) & 0.003785 & cubic meter per day (m³/d) \\
\hline inch per year (in/yr) & 25.4 & millimeter per year (mm/yr) \\
\hline \multicolumn{3}{|c|}{ Hydraulic gradient } \\
\hline foot per mile (ft/mi) & 0.1894 & meter per kilometer (m/km) \\
\hline
\end{tabular}

\section{Datums}

Vertical coordinate information was referenced to the North American Vertical Datum of 1988 (NAVD88), referred to in this report as "sea level."

Horizontal coordinate information was referenced to the North American Datum of 1983 (NAD83).

Altitude, as used in this report, refers to distance above or below sea level.

\section{Abbreviations and Acronyms}

DDMFZ Darrington-Devils Mountain Fault Zone

DEM Digital Elevation Models

Ecology Washington State Department of Ecology

HUF Hydrogeologic Unit Flow

PEST parameter estimation program

USGS U.S. Geological Survey 


\section{Well-Numbering System}

Wells in Washington State are assigned a local well number that identifies each well based on its location within a township, range, section, and 40 -acre tract. For example, local well number 33N/04E-02E01 indicates that the well is in township 33 north of the Willamette Base Line, and range 4 east of the Willamette Meridian. The numbers immediately following the hyphen indicate the section (02) within the township, and the letter following the section (E) gives the 40 -acre tract of the section. The two-digit sequence number (01) following the letter is used to distinguish individual wells in the same 40 -acre tract. $A$ " $D$ " following the sequence number indicates a well that has been deepened.

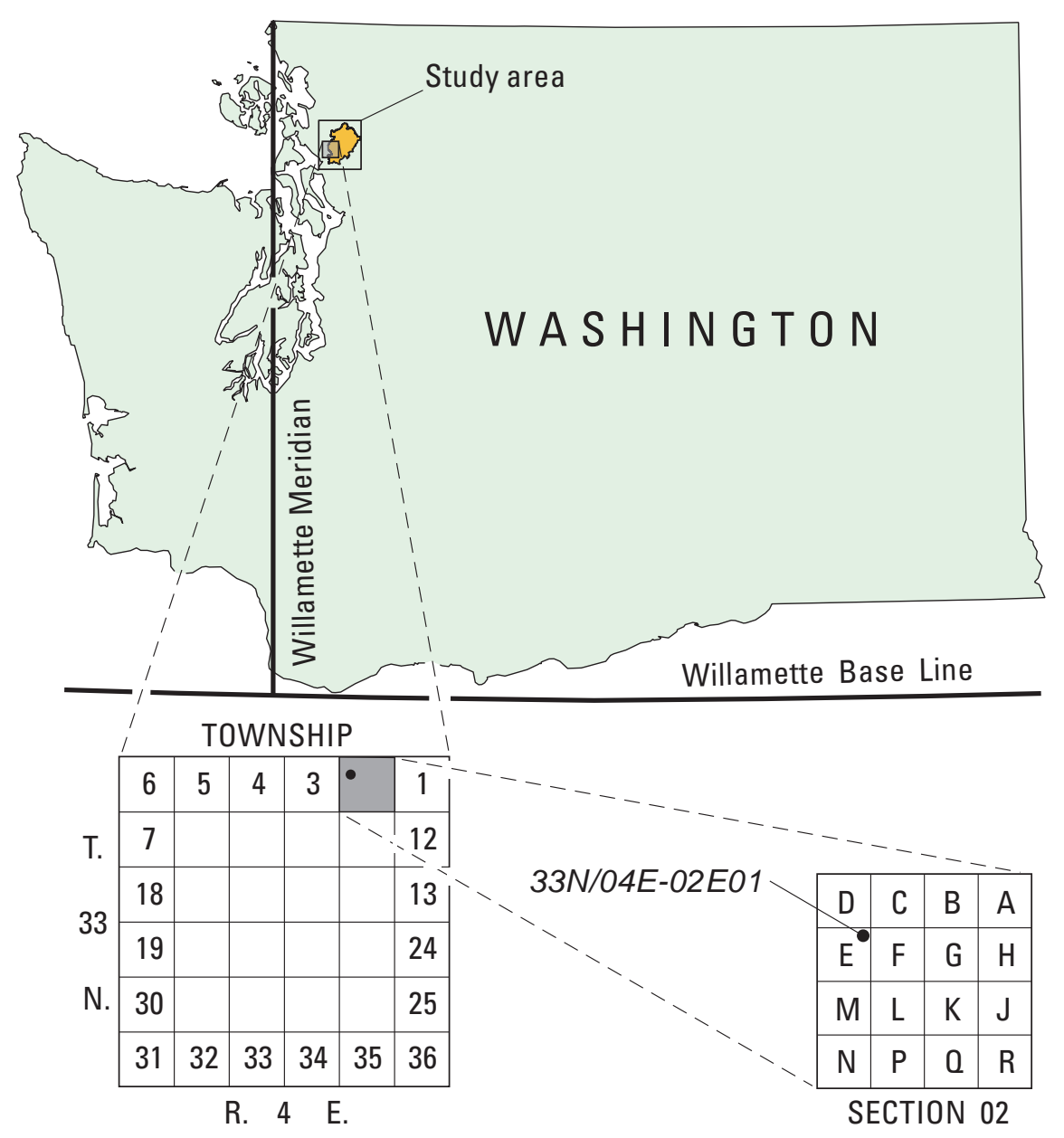




\title{
Numerical Simulation of the Groundwater-Flow System in Tributary Subbasins and Vicinity, Lower Skagit River Basin, Skagit and Snohomish Counties, Washington
}

\author{
By Kenneth H. Johnson and Mark E. Savoca
}

\section{Abstract}

A groundwater-flow model was developed to evaluate the effects of potential groundwater withdrawals and consumptive use on streamflows in tributary subbasins of the lower portion of the Skagit River basin. The study area covers about 155 square miles along the Skagit River and its tributary subbasins (East Fork Nookachamps Creek, Nookachamps Creek, Carpenter Creek, Fisher Creek) in southwestern Skagit County and northwestern Snohomish County, Washington. The Skagit River occupies a large, relatively flat alluvial valley that extends across the northern and western margins of the study area, and is bounded to the south and east by upland and mountainous terrain. The alluvial valley and upland are underlain by unconsolidated deposits of glacial and inter-glacial origin. Bedrock underlies the alluvial valley and upland areas, and crops out throughout the mountainous terrain. Nine hydrogeologic units are recognized in the study area and form the basis of the groundwater-flow model.

Groundwater flow in tributary subbasins of the lower Skagit River and vicinity was simulated using the groundwater-flow model, MODFLOW-2000. The finite-difference model grid consists of 174 rows, 156 columns, and 15 layers. Each model cell has a horizontal dimension of 500 by 500 feet. The thickness of model layers varies throughout the model area. Groundwater flow was simulated for both steady-state and transient conditions. The steady-state condition simulated average recharge, discharge, and water levels for the period, August 2006-September 2008. The transient simulation period, September 2006-September 2008, was divided into 24 monthly stress periods. Initial conditions for the transient model were developed from a 6-year "lead-in" period that used recorded precipitation and Skagit River levels, and extrapolations of other boundary conditions. During model calibration, variables were adjusted within probable ranges to minimize differences between measured and simulated groundwater levels and stream baseflows. The final calibrated steady-state and transient models have weighted mean residual of -10.1 and -2.2 feet, respectively (negative residuals indicate that measured value is less than simulated value).

Simulated inflow to the model area was about 144,000 acre-feet per year (acre-ft/yr) (81 percent of simulated inflow) from precipitation and secondary recharge, and about 32,700 acre-ft/yr (19 percent of simulated inflow) from stream and lake leakage. Simulated outflow from the model primarily was through discharge to streams and lakes (about 166,500 acre-ft/yr; 94 percent of simulated outflow), and withdrawals from wells (about 9,800 acre-ft/yr; 6 percent of simulated outflow).

Model simulations were conducted to demonstrate model performance and to provide representative examples of how the model may be used to evaluate the effects of potential changes in groundwater withdrawals, consumptive use, and recharge on groundwater levels and tributary stream baseflows.

\section{Introduction}

In Washington State, the availability of water for outof-stream uses must be determined before water can be appropriated. This determination is most often made as part of an application for a water right; however, certain uses are exempted from the water rights permitting system. To prevent water withdrawals from impacting other out-of-stream and instream uses, Washington State may reserve a specific quantity of water in a stream basin for future out-of-stream uses as part of the regulation establishing minimum instream flows (the Instream-Flow Rule, Washington State Department of Ecology, 2010). The reservation allows new groundwater withdrawals in basins where much of the available water is appropriated. Once the total of new withdrawals equals the quantity specified in the reservation, subsequent new use proposals would have to find an alternative source of water, obtain an existing water right, or provide compensating mitigation for streamflow impacts. 
Recent population growth along the Interstate 5 corridor near Mount Vernon, Washington, has led to increased water use, with many new domestic wells serving residents in the lower portion of the Skagit River basin in areas not served by a regional public water system. Planning for future development in the lower basin, including the reservation of water for new domestic wells, requires identification of areas where withdrawals from existing and new wells could adversely impact streamflow in the Skagit River or its tributaries. Skagit County, as the land use authority for unincorporated areas, requires a scientifically credible basis for implementing land-use restrictions to protect instream resources.

In June 2006, the U.S. Geological Survey (USGS), in cooperation with Skagit County, the Washington State Department of Ecology (Ecology), and Skagit County Public Utility District No. 1, began a project to characterize the groundwater- and surface-water flow system in the tributary subbasins of the lower portion of the Skagit River and vicinity, and to integrate this and other information into a groundwater-flow model to evaluate the effects of potential groundwater withdrawals and consumptive use on tributary streamflows.

\section{Purpose and Scope}

This report documents the development and calibration of a numerical model to simulate groundwater flow in tributary subbasins of the Skagit River and vicinity. The model described in this report can be used to assess the regional impacts of groundwater withdrawals on groundwater levels, and on groundwater discharge to streams. This report presents the information used to construct and calibrate the model, and provides assessments of model performance in simulating measured hydrologic conditions, and a discussion of model limitations. Information used to construct and calibrate the numerical model was based on the work of Fasser and Julich (2009) and Savoca and others (2009a).

\section{Description of Study Area}

The study area covers about $155 \mathrm{mi}^{2}$ along the Skagit River and its tributary subbasins in southwestern Skagit County and northwestern Snohomish County, Washington (fig. 1), and was selected to include major hydrologic features that could be used as regional model boundaries in the numerical simulation of the groundwater-flow system. The Skagit River occupies a large, relatively flat alluvial valley that extends across the northern and western margins of the study area, and is bounded to the south and east by upland and mountainous terrain. The alluvial valley primarily is underlain by fluvial sand and gravel deposits associated with the present and ancient Skagit River, and locally preserved lahar runout deposits originating from Glacier Peak, located about $55 \mathrm{mi}$ east-southeast of the study area. Upland areas contain laterally discontinuous bodies of glacial and inter-glacial deposits that reflect both terrestrial and shallow marine depositional environments. Bedrock underlies the alluvial valley and upland areas, and crops out throughout the mountainous terrain.

The southwest-flowing Skagit River receives streamflow from four tributary subbasins that originate within the mountainous interior of the study area: East Fork Nookachamps Creek, Nookachamps Creek, Carpenter Creek, Fisher Creek. These creeks drain areas of about 37, 28, 19, and $10 \mathrm{mi}^{2}$, respectively. The lower reaches of most creeks flow year-round; however, intermittent flow conditions are common in middle and upper creek reaches during the summer months. Backwater conditions periodically occur near the confluence of creeks with the Skagit River. Springs are present throughout the study area, and contribute to late-summer, baseflow to creeks. Several lakes are present in the study area.

The study area has a temperate marine climate with warm, dry summers, and cool, wet winters with snow and freezing temperatures common at high altitudes. Normal annual precipitation (average annual precipitation for 1971-2000) is 46.6 in. at Sedro-Woolley and 32.7 in. at Mount Vernon (National Oceanic and Atmospheric Administration, 2007). Land-surface altitude in the study area ranges from about $10 \mathrm{ft}$ in the Skagit River valley to nearly 4,000 ft in the mountainous areas.

\section{Groundwater-Flow System}

This section describes the hydrogeologic units that comprise the groundwater-flow system in the study area, and includes discussions of recharge, flow direction, discharge, exchange of water between the aquifer system and creeks, temporal fluctuations in groundwater levels, and water budget. This information was used to construct and calibrate the numerical model, and is based on the work of Fasser and Julich (2009) and Savoca and others (2009a).

\section{Geologic Setting}

The geology of the study area records a complex history of accretion along the continental margin, mountain building, deposition of terrestrial and marine sediments, igneous intrusion, and the repeated advance and retreat of continental glaciers. Bedrock in the study area consists of: (1) complex assemblages of faulted and folded low-grade metamorphic rocks formed during Late Jurassic or Early Cretaceous continental margin subduction; (2) Tertiary sedimentary units deposited in alluvial fan, braided stream, and near-shore shallow marine settings; and (3) Tertiary igneous intrusive and extrusive rocks. Metamorphic rocks were likely brought to the surface by Mid-Cretaceous thrust faulting and Tertiary displacement along the Darrington-Devils Mountain Fault Zone (DDMFZ). Evidence of Quaternary displacement along 


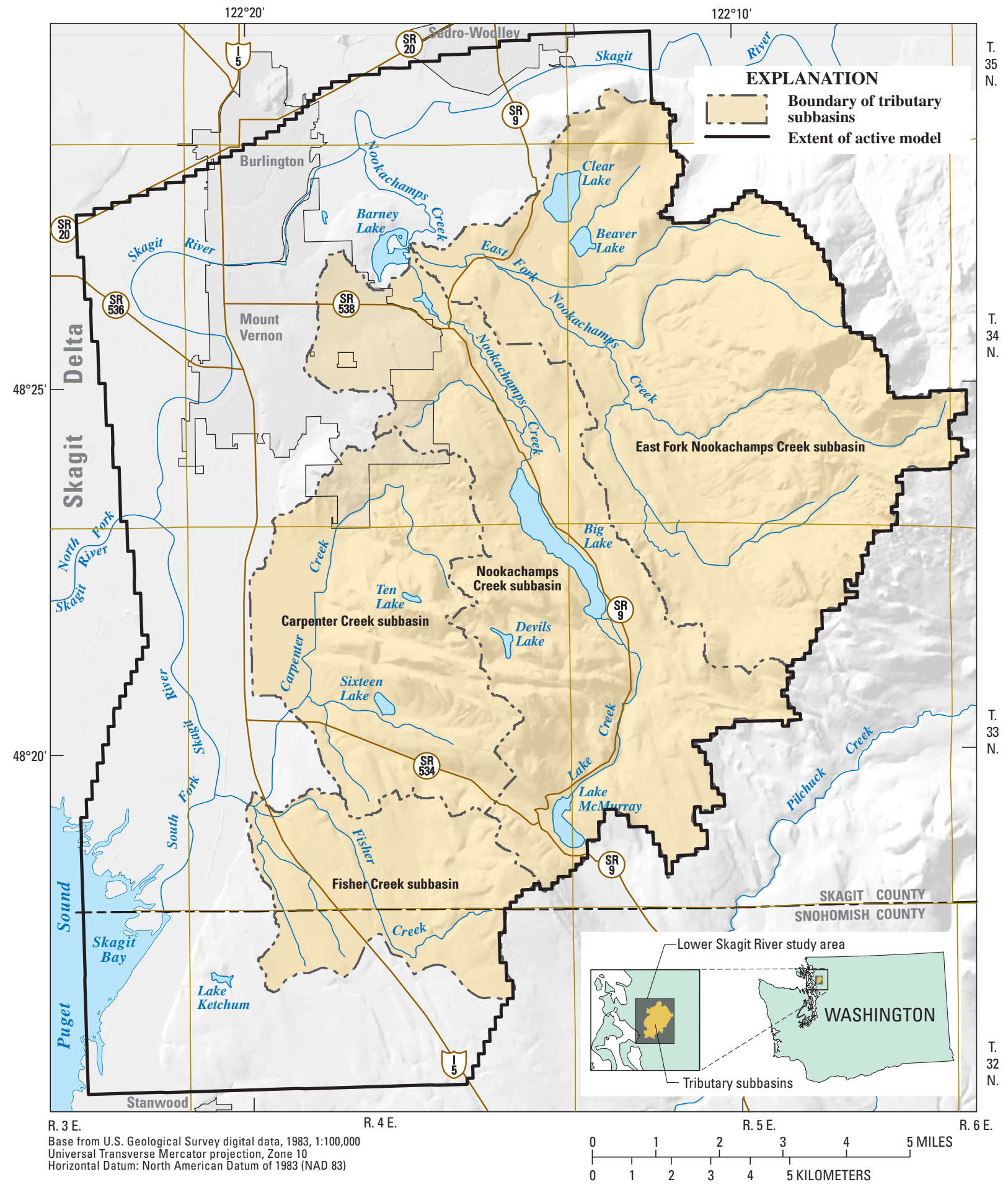

Figure 1. Location of tributary subbasins and vicinity, lower Skagit River basin, Washington. 
the DDMFZ and other faults in the study area has not been widely documented. Dragovich and DeOme (2006) offer evidence of Holocene offset along a mile-long portion of the main strand of the DDMFZ located north of Lake McMurray.

Continental glaciers advanced into the study area several times during the Pleistocene Epoch. The most recent period of glaciation began about 17,000 years ago when the continental ice sheet in Canada expanded, and advanced southward, eventually covering the entire Puget Sound Basin before halting and retreating. Beginning about 13,500 years ago, the climate warmed and the lobe wasted back allowing marine waters to enter the Puget Sound basin, which had been depressed due to glacial isostatic loading. Marine inundation buoyed the retreating ice and produced marine and estuarine conditions in the study area. Postglacial filling of the Skagit River valley, which had been excavated by subglacial melt water, was accomplished through Holocene fluvial, estuarine, and deltaic deposition, and volcanic lahar deposits originating from Glacier Peak.

Unconsolidated deposits of glacial and inter-glacial origin are present throughout the study area. A typical glacial sequence progresses from advance outwash, to till, to recessional outwash. Fluvial, lacustrine, bog and marsh depositional environments were common during inter-glacial periods. Beneath these unconsolidated deposits of varying thickness are bedrock units that are exposed in large parts of the glacial upland and within the mountains along the eastern margin of the study area.

\section{Hydrogeologic Units}

Savoca and others (2009a) described nine hydrogeologic units in the study area (table 1). Geologic units were grouped into hydrogeologic units, consisting of aquifers and confining units, on the basis of lithologic (depositional facies, grain size and sorting) and hydrologic (hydraulic conductivity and unit geometry) characteristics. Glacial deposits generally are heterogeneous, and although a glacial aquifer may be composed primarily of sand or gravel, it may locally contain varying amounts of clay or silt. Conversely, a confining layer composed predominantly of silt or clay, may contain local lenses of coarse material. These small-scale variations in lithology may influence the occurrence and movement of groundwater at a scale that is likely too small to be adequately represented by the regional-scale groundwater-flow model constructed for this study.

Local-scale variability in the distribution of glacial depositional facies often results in the formation of spatially discontinuous units of varying thickness (Savoca and others, 2009a, figs. 2-8). Therefore, most units are not aerially contiguous throughout the study area, and unit thickness may vary considerably over short distances. Glacial and inter-glacial deposits are interpreted as largely absent within the Skagit River valley to a depth of approximately $300 \mathrm{ft}$ below sea level, likely due to removal by southward flowing subglacial melt water, prior to subaerial exposure of the glacier bed during ice recession (Booth, 1994; Dragovich and others, 1994). Infilling of the Skagit River valley was accomplished through the accumulation of Holocene fluvial, estuarine, and deltaic deposits, and volcanic lahar deposits originating from Glacier Peak.

\section{Hydraulic Conductivity}

Horizontal hydraulic conductivity was initially estimated for the hydrogeologic units using drawdown data from drillers' $\operatorname{logs}$ (Savoca and others, 2009a, table 3). Only data from those wells that had a driller's log containing discharge rate, time of pumping, drawdown, static water level, well-construction data, and lithologic log were used. The median values of estimated hydraulic conductivity for the aquifers are similar in magnitude to values reported by Freeze and Cherry (1979) for similar materials: Qago, $47 \mathrm{ft} / \mathrm{d}$; Qga, $48 \mathrm{ft} / \mathrm{d}$; Qco, $57 \mathrm{ft} / \mathrm{d}$ : Qooa, $26 \mathrm{ft} / \mathrm{d}$; and OEc, $0.27 \mathrm{ft} / \mathrm{d}$. Median values of estimated hydraulic conductivity for the confining units (Qgt, $13 \mathrm{ft} / \mathrm{d}$; Qgl, $26 \mathrm{ft} / \mathrm{d}$; Qot, $11 \mathrm{ft} / \mathrm{d}$ ) and bedrock unit (EJTP, $0.13 \mathrm{ft} / \mathrm{d}$ ) are higher than is typical for most of the material in these units because the available data for confining units usually are from wells that are preferentially open to lenses of coarse material, or in the case of bedrock, where fractures exist. As a result, the data are biased toward the more productive zones in these units and are not representative of the entire unit. Initial hydraulic conductivity values were refined during the model calibration process and final values used in the model are presented later in this report.

\section{Recharge}

Precipitation is the dominant source of water recharging the groundwater system in the study area, and it is reasonable to expect variations in recharge to be related to spatial and temporal variations in precipitation. However, factors such as the permeability of surficial hydrogeologic units and land-cover characteristics also affect recharge; therefore, the relation between precipitation and recharge is likely to vary according to hydrogeologic and land-cover characteristics. The distribution of recharge from precipitation in the four tributary subbasins was estimated by applying precipitation-recharge relations (Savoca and others, 2009a) based on regression equations developed for areas in Washington State by Bidlake and Payne (2001) that incorporate the effects of surficial hydrogeology and tree canopy characteristics. The effects of impervious surfaces on the distribution of recharge from precipitation also were estimated in the study area. The tributary subbasins received about 284,000 acre-ft or about 56 in. of precipitation during an average year (Savoca and others, 2009a). Precipitation during an average year for each sub-basin was: East Fork Nookachamps Creek, 136,920 acre-ft (70 in/yr); Nookachamps Creek, 74,820 acre-ft (49 in/yr); Carpenter Creek, 46,610 acre-ft (46 in/yr); and Fisher Creek, 25,730 acre-ft (47 in/yr). 
Table 1. Lithologic and hydrologic characteristics of hydrogeologic units, tributary subbasins and vicinity, lower Skagit River basin, Washington.

\begin{tabular}{|c|c|}
\hline $\begin{array}{l}\text { Hydrogeologic unit } \\
\text { (Savoca and others, 2009a) }\end{array}$ & $\begin{array}{l}\text { Lithologic and hydrologic characteristics } \\
\text { (refer to Savoca and others, 2009a, for unit extent and thickness maps) }\end{array}$ \\
\hline $\begin{array}{l}\text { Alluvial and recessional } \\
\text { outwash aquifer (Qago) }\end{array}$ & $\begin{array}{l}\text { The aquifer consists of sand, gravel, and cobbles, with minor lenses of silt and clay. Thickness } \\
\text { typically ranges from } 10 \text { to } 50 \text { feet in upland areas, and } 200 \text { to } 450 \text { feet in the Skagit River valley. } \\
\text { Groundwater in this aquifer is unconfined where it is not fully saturated or exposed at land surface, } \\
\text { however, confined conditions are likely where it is fully saturated and overlain by the till confining } \\
\text { unit. }\end{array}$ \\
\hline Advance outwash aquifer (Qga) & $\begin{array}{l}\text { The aquifer consists mostly of sand and gravel with minor amounts of silt, and scattered layers of } \\
\text { pebble-cobble gravel and local silt and clay interbeds. Thickness typically ranges from } 10 \text { to } 100 \text { feet, } \\
\text { but exceeds } 200 \text { feet in places. In most of the study area, groundwater in this aquifer is confined by } \\
\text { the overlying till confining unit, however, unconfined conditions may occur locally where it is not } \\
\text { fully saturated or is exposed at land surface. }\end{array}$ \\
\hline Inter-glacial alluvial aquifer (Qco) & $\begin{array}{l}\text { The aquifer primarily consists of sand, gravel, silt, and clay, with minor lenses of gravel and cobbles, } \\
\text { and commonly is } 10 \text { to } 50 \text { feet thick, but thickness exceeds } 100 \text { feet in places. In most of the study } \\
\text { area, the inter-glacial alluvial aquifer is overlain by either the glaciolacustrine-distal outwash or till } \\
\text { confining units, and groundwater occurs under confined conditions. Unconfined conditions occur in } \\
\text { limited areas where the aquifer may not be fully saturated or where it is exposed at land surface. }\end{array}$ \\
\hline Older till confining unit (Qot) & $\begin{array}{l}\text { This low-permeability unit is composed of terrestrial glacial diamicton consisting of various proportions } \\
\text { of clay, silt, sand, and gravel, with scattered cobbles, and boulders. Limited well data indicate that } \\
\text { thickness typically ranges from } 10 \text { to } 20 \text { feet, and locally exceeds } 50 \text { feet. }\end{array}$ \\
\hline $\begin{array}{l}\text { Igneous and metamorphic } \\
\text { bedrock unit (EJTP) }\end{array}$ & $\begin{array}{l}\text { This low-permeability unit is composed of volcanic and metamorphic rocks and consists of rhyolite, } \\
\text { andesite, basalt, and complex assemblages of low-grade metasediments, metavolcanics, and meta- } \\
\text { intrusives, and is considered to be non-water bearing except in localized areas of fracturing. }\end{array}$ \\
\hline
\end{tabular}

\section{Groundwater-Flow Directions}

Groundwater levels measured during operation of the monthly monitoring network (October 2006-September 2008) were used to evaluate groundwater-flow directions in study area aquifers (Savoca and others, 2009a, figs. 14-18). The mean water-level value was used to represent the water-level altitude at monthly monitoring wells for the analysis of groundwater-flow directions. Synoptic groundwater levels measured during the field inventory (August-October 2006) were used only in areas where monthly water-level data were not available. Groundwater flow in unconsolidated aquifers generally is towards the west and northwest, towards the Skagit River and Puget Sound. This generalized flow pattern is likely complicated by the presence of large areas of low permeability glacial till that separate discontinuous bodies of aquifer material, and act as local groundwater-flow barriers. 
Groundwater-flow directions in the sedimentary aquifer likely reflect both local and regional flow patterns. Recharge to the sedimentary aquifer preferentially occurs in mountainous areas where the unit is exposed at land surface. Water-level altitudes in these areas reflect local topographic relief and suggest radial flow from bedrock highs down beneath the surrounding unconsolidated sediments. Westward groundwater flow in the sedimentary aquifer occurs along the mountain front in the eastern part of the study area, and is coincident with a regional westward decrease in land surface altitude from the mountains to the Puget Sound.

Vertical flows in the groundwater system are difficult to determine because extents and thicknesses of hydrogeologic units vary considerably throughout the study area, the presence of confining units within and between aquifers is highly variable, and water-level data for comparison between adjacent units are widely spaced. Water-level altitude differences between the advance outwash and inter-glacial alluvial aquifers in the southwestern part of the study area, where sufficient contoured data were available to make a comparison, indicate downward vertical flow. The potential for upward groundwater movement, indicated by the presence of flowing wells, was observed in the alluvial and recessional outwash aquifer along the eastern margin of the Skagit River valley, and in the advance outwash aquifer near Big Lake and along the mountain front. A continuously flowing well completed in the older outwash and alluvial aquifer indicates the potential for upward flow in the southwestern part of the study area, and upward flow in the sedimentary aquifer is indicated by an intermittent flowing well adjacent to Lake McMurray.

\section{Discharge}

Groundwater in the study area discharges as seepage to streams, lakes, springs, and marshes; as evapotranspiration of shallow groundwater; as submarine seepage to Puget Sound; and as withdrawals from wells. Groundwater discharge sustains the late-summer and early-fall streamflow (baseflow) of creeks in the study area. Estimates of groundwater discharge to creeks in the tributary subbasins were based on synoptic streamflow measurements conducted in August 2007 and June 2008 (Savoca and others, 2009a). Groundwater discharge estimates represent flow from contributing areas upstream of the synoptic streamflow measurement sites $\left(57.7 \mathrm{mi}^{2}\right)$ and do not include contributing areas in downstream portions of the subbasins $\left(36.6 \mathrm{mi}^{2}\right)$. A total net of approximately13.15 $\mathrm{ft}^{3} / \mathrm{s}$ (9,520 acre- $\left.\mathrm{ft} / \mathrm{yr}\right)$ of groundwater discharged to creeks measured during August 2007, and approximately $129.6 \mathrm{ft}^{3} / \mathrm{s}$ (93,830 acre-ft/yr) of groundwater discharged to creeks measured during June 2008. The time-averaged (mean of the 2007 and 2008 discharge measurements), area-weighted groundwater discharge for the entire tributary subbasin area was estimated to be $83.43 \mathrm{ft}^{3} / \mathrm{s}$ $(60,400 \mathrm{acre}-\mathrm{ft} / \mathrm{yr})$. This value includes area-weighted estimates of groundwater discharge for portions of subbasins that were downstream of synoptic measurement sites. Groundwater withdrawals from wells in the tributary subbasins in 2008 were an estimated 2,200 acre-ft of water. This quantity represents gross withdrawals (public water supply, domestic use, and crop irrigation) and does not reflect the quantity of water returned to the groundwater system through septic tanks or through irrigation return flows to shallow aquifers (Savoca and others, 2009a).

\section{Groundwater and Surface-Water Interactions}

Characterization of the exchange of water between the groundwater system and creeks in the study area was based on synoptic stream baseflow measurements conducted in August 2007 and June 2008 (Savoca and others, 2009a). This information was used to identify stream reaches that either gain flow from or lose flow to the shallow groundwater system. August 2007 streamflow measurements were made during the low-flow season, usually July-August, to capture baseflow conditions. June 2008 measurements were made to document the exchange of water between the groundwater system and creeks at a higher baseflow condition with larger groundwater contributions. The synoptic streamflow data illustrate a general pattern in which the upper reaches of creeks in the study area tended to gain flow from the groundwater system, and lower creek reaches tended to lose flow. Significant inflows from tributaries to major creeks in the study area suggest the presence of groundwater discharge from upland areas underlain by bedrock. Pitz and Garrigues (2000) noted that discharge to tributaries of Carpenter Creek are likely derived in large part from groundwater fracture flow within upland bedrock areas during low-flow conditions. Groundwater discharge from permeable clastic units $(\mathrm{OEc})$ also is a likely contributor to baseflow in upland areas.

\section{Groundwater-Level Fluctuations}

Seasonal changes in groundwater levels that follow a typical pattern for shallow wells in western Washington were observed in many tributary sub-basin wells (Fasser and Julich, 2009). Water levels rise from October through March, when precipitation and river stage are high, and decline from April through September, when precipitation and river stage are low (Savoca and others, 2009a). Water-level fluctuations during the monitoring period (October 2006-September 2008) were largest in wells completed in the sedimentary aquifer $(\mathrm{OEc})$, and ranged from about 3 to $27 \mathrm{ft}$. Water levels in wells completed in the unconsolidated hydrogeologic units exhibited seasonal variations ranging from less than 1 to about $10 \mathrm{ft}$. 


\section{Water Budget}

An approximate water budget for average precipitation during the study period (September 1, 2006 -August 31, 2008) in the four tributary sub-basin area, as well as each individual sub-basin (Savoca and others, 2009a), is presented in table 2. Precipitation during the study period averaged an estimated
$56 \mathrm{in} / \mathrm{yr}$ over the tributary subbasins. Approximately one-third (33 percent) of precipitation enters the groundwater system in the subbasins as recharge. Most of this recharge (65 percent) discharges to creeks, and only about 3 percent is withdrawn from wells. The remaining groundwater recharge ( 32 percent) leaves the sub-basin groundwater system as discharge to the Skagit River and Puget Sound.

Table 2. Estimated average annual water budget for tributary subbasins, lower Skagit River basin, Washington, September 1, 2006 to August 31, 2008.

$[<$, less than $]$

\begin{tabular}{lrrr}
\hline \multirow{2}{*}{ Water-budget component } & \multicolumn{2}{c}{ Quantity } & \\
\cline { 2 - 3 } & $\begin{array}{c}\text { Inches } \\
\text { per year }\end{array}$ & $\begin{array}{c}\text { Acre-feet } \\
\text { per year }\end{array}$ & Percent \\
\hline & & & \\
\hline Precipitation & & & \\
Fate of precipitation & 20 & 100,200 & 35 \\
$\quad$ Surface runoff & 18 & 91,400 & 32 \\
Evapotranspiration & 18 & 92,400 & 33 \\
Groundwater recharge & 56 & 284,000 & 100 \\
$\quad$ Total precipitation & & & \\
Fate of recharge & 12 & 60,400 & 65 \\
$\quad$ Discharge to creeks & 6 & 29,800 & 32 \\
Other natural discharge & $<1$ & 2,200 & 3 \\
$\quad$ Withdrawals from wells & 18 & 92,400 & 100 \\
$\quad$ Total recharge & & & \\
\hline
\end{tabular}

East Fork Nookachamps Creek subbasin

\section{Precipitation}

Fate of precipitation

Surface runoff

Evapotranspiration

Groundwater recharge

Total precipitation

Fate of recharge

Discharge to creeks

Other natural discharge

Withdrawals from wells

Total recharge

$\begin{array}{rrr}27 & 52,960 & 39 \\ 22 & 42,900 & 31 \\ 21 & 41,060 & 30 \\ 70 & 136,920 & 100\end{array}$

\begin{tabular}{rrr}
18 & 34,740 & 85 \\
3 & 6,300 & 15 \\
$<1$ & 20 & $<1$ \\
21 & 41,060 & 100 \\
\hline
\end{tabular}

Nookachamps Creek subbasin

\begin{tabular}{cc}
\hline Water-budget component & \begin{tabular}{c} 
Quantity \\
\cline { 2 - 2 } $\begin{array}{c}\text { Inches Acre-feet } \\
\text { per year }\end{array}$ per year
\end{tabular} \\
\hline Carpenter Creek subbasin \\
\hline
\end{tabular}

Precipitation

Fate of precipitation

Surface runoff

Evapotranspiration

Groundwater recharge

Total precipitation

Fate of recharge

Discharge to creeks

Other natural discharge

Withdrawals from wells

Total recharge

$\begin{array}{rrr}18 & 17,720 & 38 \\ 11 & 11,690 & 25 \\ 17 & 17,200 & 37 \\ 46 & 46,610 & 100\end{array}$

\begin{tabular}{lrrr} 
& \multicolumn{1}{c}{ Fisher Creek subbasin } & \\
\hline Precipitation & & & \\
Fate of precipitation & 8 & 4,610 & 18 \\
$\quad$ Surface runoff & 20 & 10,820 & 42 \\
$\quad$ Evapotranspiration & 19 & 10,300 & 40 \\
$\quad$ Groundwater recharge & 47 & 25,730 & 100 \\
$\quad$ Total precipitation & & & \\
Fate of recharge & 7 & 3,590 & 35 \\
$\quad$ Discharge to creeks & 12 & 6,580 & 64 \\
$\quad$ Other natural discharge & $<1$ & 130 & 1 \\
$\quad$ Withdrawals from wells & 19 & 10,300 & 100 \\
$\quad$ Total recharge & & & \\
\hline
\end{tabular}

\begin{tabular}{lrrr}
\multicolumn{2}{c}{ Nookachamps Creek subbasin } & \\
\cline { 1 - 2 } Precipitation & & & \\
Fate of precipitation & 16 & 24,870 & 33 \\
$\quad$ Surface runoff & 17 & 26,110 & 35 \\
$\quad$ Evapotranspiration & 16 & 23,840 & 32 \\
$\quad$ Groundwater recharge & 49 & 74,820 & 100 \\
$\quad$ & & & \\
$\quad$ Total precipitation & 11 & 16,610 & 70 \\
Fate of recharge & 5 & 7,020 & 30 \\
$\quad$ Discharge to creeks & $<1$ & 210 & $<1$ \\
$\quad$ Other natural discharge & 16 & 23,840 & 100 \\
$\quad$ Withdrawals from wells & & \\
$\quad$ Total recharge & & & \\
\end{tabular}




\section{Numerical Simulation of the Groundwater-Flow System}

Groundwater flow in tributary subbasins of the lower Skagit River and vicinity was simulated using the U.S. Geological Survey modular three-dimensional finite-difference groundwater-flow model, MODFLOW-2000 (Harbaugh and others, 2000). MODFLOW-2000 is a computer program that numerically solves the three-dimensional groundwater-flow equation for a porous medium using the finite-difference method. The modular design of MODFLOW-2000 uses packages to simulate groundwater-flow system processes, such as recharge, groundwater flow, discharge, and interactions between the aquifer and surface-water bodies. The model described in this report was developed to simulate steady-state and transient conditions. Steady-state conditions exist when the volume of water flowing into the system is equal to the volume flowing out. The simulation of transient conditions incorporates monthly variations in recharge, discharge, and other groundwater-flow system processes.

\section{Spatial and Temporal Discretization}

The model area was subdivided, horizontally and vertically, into rectilinear blocks called cells. The hydraulic properties of the material in each cell are assumed to be homogeneous. A model grid of 174 rows, 156 columns, and 15 layers was used to represent the groundwater-flow system (fig. 2). In the horizontal direction, each cell has a dimension of 500 by $500 \mathrm{ft}$. The thickness of model layers varies throughout the model area. All fifteen model layers are active throughout the entire model area. The bottom of the model (bottom of model layer 15) is an implicit no-flow boundary.

The model simulates both steady-state and transient conditions. The steady-state condition simulates average recharge, discharge, and water levels for the study period (August 2006-September 2008). The transient simulation period (September 2006-September 2008) was divided into 24 monthly stress periods to represent temporal variations in recharge, discharge, and other groundwater-flow system processes. Each stress period consists of one time step to coincide with the frequency of data collected in the field, and because smaller time steps were not necessary for stable operation of the model. Initial conditions for the transient model were developed from a 6-year "lead-in" period that used recorded precipitation and Skagit River levels, and extrapolations of other boundary conditions.

\section{Hydrogeologic Framework}

A three-dimensional hydrogeologic framework, composed of nine hydrogeologic units (table 1), was developed by Savoca and others (2009a) for the study area. Most units are not spatially contiguous throughout the study area, and unit thickness and altitude may vary considerably over short distances. In order to accurately represent the discontinuous and variable character of the hydrogeologic units, the Hydrogeologic-Unit Flow (HUF) Package (Anderman and Hill, 2000) of MODFLOW-2000 was used. The HUF Package allows the model to compute average hydraulic properties for model cells with more than one hydrogeologic unit, and each unit has properties that can be adjusted during model calibration. The presentation of model results using the HUF Package is limited because water levels are computed for numerical layers and cannot be strictly assigned to individual HUF units within the layer.

Fourteen HUF units (table 3; figs. 3A-I) were established to simulate the three-dimensional distribution and variable character of hydrogeologic units in the model domain. Each of the HUF units is represented within the three-dimensional model grid by the altitude of its top and its thickness. The HUF package calculates effective hydrologic properties for each model cell based on the hydrologic properties of HUF units present within the cell. During model construction, the hydrogeologic framework was represented by a series of vertically stacked HUF units that span the entire model domain; HUF units were assigned a thickness of zero in areas where units are not present (figs. 3A-I). The complex relation between hydrogeologic units represented using HUF units and numerical model layers that commonly contain more than one unit is illustrated in a vertical section through the model (fig. 4) that corresponds with hydrogeologic section $C$ - $C^{\prime}$ in Savoca and others (2009a, pl. 2).

Glacial and inter-glacial deposits are interpreted as largely absent within the Skagit River valley to a depth of approximately $300 \mathrm{ft}$ below sea level, likely due to removal by southward flowing subglacial melt water, prior to subaerial exposure of the glacier bed during ice recession (Booth, 1994; Dragovich and others, 1994). These undifferentiated deposits were simulated using a single HUF unit (HUF8) to represent a composite of probable aquifers and intervening confining units.

The sedimentary aquifer $(\mathrm{OEc})$ was simulated using four HUF units (table 3) to represent different hydraulic properties associated with the Bulson Creek (poorly cemented; high permeability) and Chuckanut (well cemented; low permeability) geologic units, and to account for an 


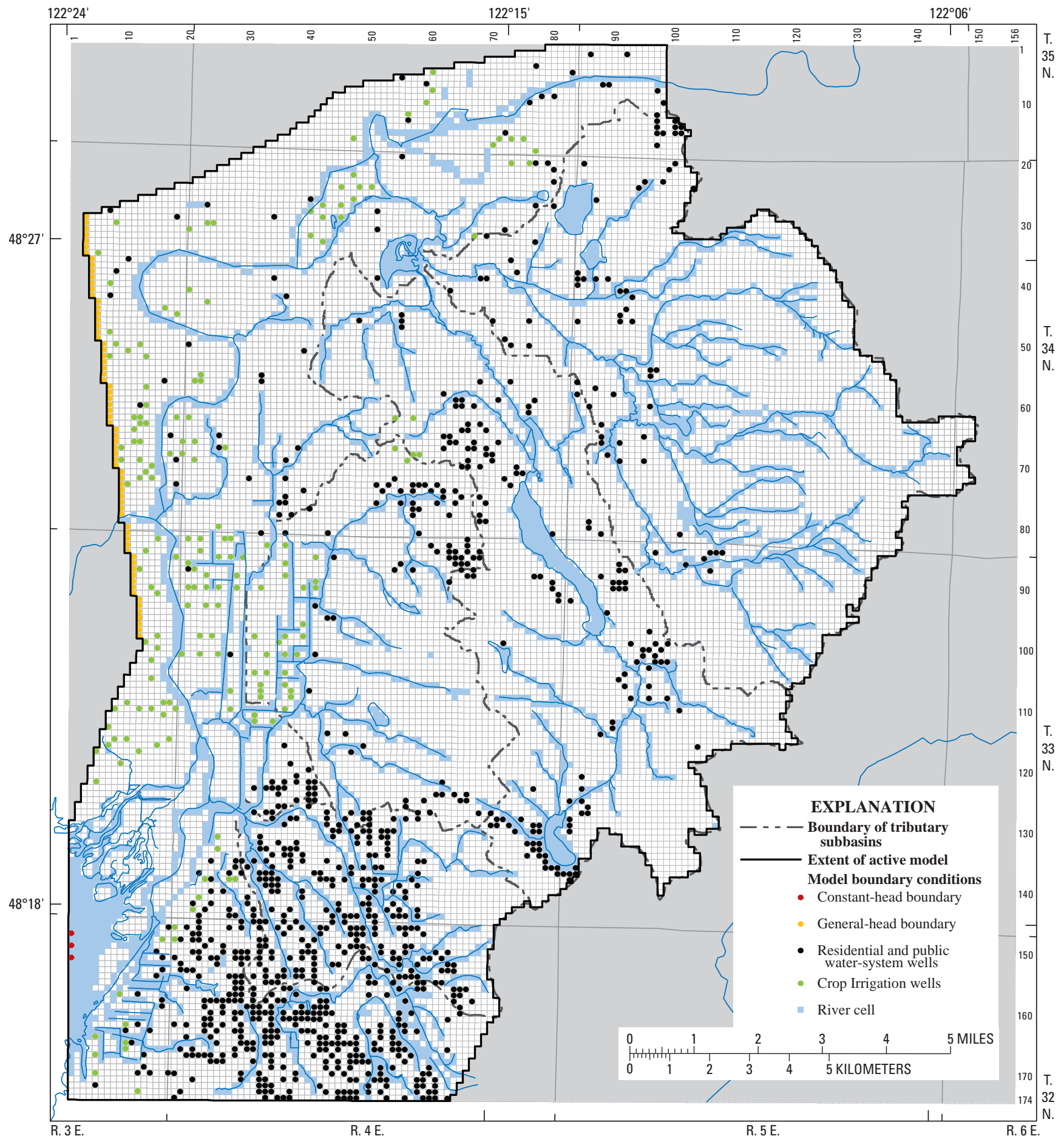

Figure 2. Locations of model river, general head, and constant-head cells, domestic and public supply wells, and irrigation wells, tributary subbasins and vicinity, lower Skagit River basin, Washington. 
Table 3. Initial hydraulic property values of HUF units used in the steady-state model, tributary subbasins and vicinity, lower Skagit River basin, Washington.

[A bbreviations: $\mathrm{ft} / \mathrm{d}$, foot per day; $\mathrm{ft}^{-1}$, per foot thickness of unit]

\begin{tabular}{|c|c|c|c|c|c|}
\hline $\begin{array}{c}\text { Hydrogeologic unit } \\
\text { (Savoca and others, 2009a) }\end{array}$ & $\begin{array}{c}\text { Hydrogeologic } \\
\text { unit flow } \\
\text { designation }\end{array}$ & $\begin{array}{l}\text { Horizontal } \\
\text { hydraulic } \\
\text { conductivity } \\
\text { (ft/d) }\end{array}$ & $\begin{array}{c}\text { Vertical } \\
\text { hydraulic } \\
\text { conductivity } \\
\text { (ft/d) }\end{array}$ & $\begin{array}{l}\text { Vertical } \\
\text { anisotropy }\end{array}$ & $\begin{array}{c}\text { Specific } \\
\text { storage } \\
\left(\mathrm{ft}^{-1}\right)\end{array}$ \\
\hline Alluvial and recessional outwash aquifer (Qago) & HUF1 & 47 & 4.7 & 10 & 0.15 \\
\hline Till confining unit (Qgt) & HUF2 & 1.5 & 0.015 & 100 & 0.15 \\
\hline Advance outwash aquifer (Qga) & HUF3 & 48 & 4.8 & 10 & 0.15 \\
\hline Inter-glacial alluvial aquifer (Qco) & HUF5 & 20 & 2 & 10 & 0.001 \\
\hline Oldert till confining unit (Qot) & HUF6 & 1 & 0.01 & 100 & 0.001 \\
\hline Older outwash and alluvial aquifer (Qooa) & HUF7 & 40 & 4.0 & 10 & 0.001 \\
\hline Undifferentiated glacial and inter-glacial deposits ${ }^{1}$ & HUF8 & 6 & 0.2 & 30 & 0.05 \\
\hline $\begin{array}{l}\text { Igneous and metamorphic bedrock unit (EJTP) with } \\
\text { secondary permeability }\end{array}$ & HUF13 & 0.07 & 0.7 & 0.1 & 0.001 \\
\hline $\begin{array}{l}\text { Igneous and metamorphic bedrock unit (EJTP) without } \\
\text { secondary permeability }\end{array}$ & HUF14 & 0.007 & 0.007 & 1 & 0.0001 \\
\hline
\end{tabular}

${ }^{1}$ Not a designated hydrogeologic unit in Savoca and others (2009a). This unit represents undifferentiated Quaternary glacial and inter-glacial deposits likely present in the Skagit River valley beneath approximately 300 feet of Holocene alluvial deposits.

${ }^{2} \mathrm{HUF}$ unit composed of Bulson Creek $\left(\mathrm{OEC}_{\mathrm{b}}\right.$ ) geologic unit (Savoca and others, 2009a.)

${ }^{3} \mathrm{HUF}$ unit composed of Chuckanut $\left(\mathrm{EC}_{\mathrm{bc}}\right)$ geologic unit (Savoca and others, 2009a). HUF units 9, 10, and 13 denote upper 200 feet of units containing secondary permeability features. HUF units 11,12 , and 14 denote deeper portion of units (below 200 feet) that do not contain secondary permeability features.

assumed depth dependence on the effectiveness of secondary permeability features (joints and fractures). These features are likely to remain "open" and facilitate groundwater movement within the upper $200 \mathrm{ft}$ of unit thickness. Compressive forces in deeper portions of these units (greater than $200 \mathrm{ft}$ ) are expected to prevent the development and /or reduce the "open dimension" of secondary permeability features; resulting in a reduction or elimination of groundwater movement along these features. The igneous and metamorphic bedrock unit (EJTP) was simulated using two HUF units to account for secondary permeability features.

\section{Hydraulic Properties}

Hydrogeologic units in the study area are texturally variable and likely exhibit a range of spatial variability in hydraulic properties. This spatial heterogeneity is not well documented in the study area, and model parameters defining the hydraulic properties of HUF units were considered to be calibration variables. Where available, initial estimates of probable values for these parameters were obtained from previously published reports in and adjacent to the study area (Thomas and others, 1997; GeoEngineers, 2003; Savoca and others, 2009a) as well as standard reference published values (Freeze and Cherry, 1979; Fetter, 1988). Initially a uniform distribution of hydraulic parameter values was specified in the numerical model for each HUF unit. Initial values were subsequently modified during model calibration; however, a uniform distribution of modified parameter values (one value per parameter for each unit) was maintained.

Unconfined and confined conditions are present in the tributary subbasins groundwater-flow system and effect the movement and storage of groundwater. Unconfined conditions occur when the upper surface of the saturated zone is at atmospheric pressure and is free to rise and decline in response to changes in groundwater recharge and discharge. Confined conditions occur when groundwater pressure exceeds atmospheric pressure due to the presence of a less permeable overlying unit that constrains the thickness of the saturated zone. 


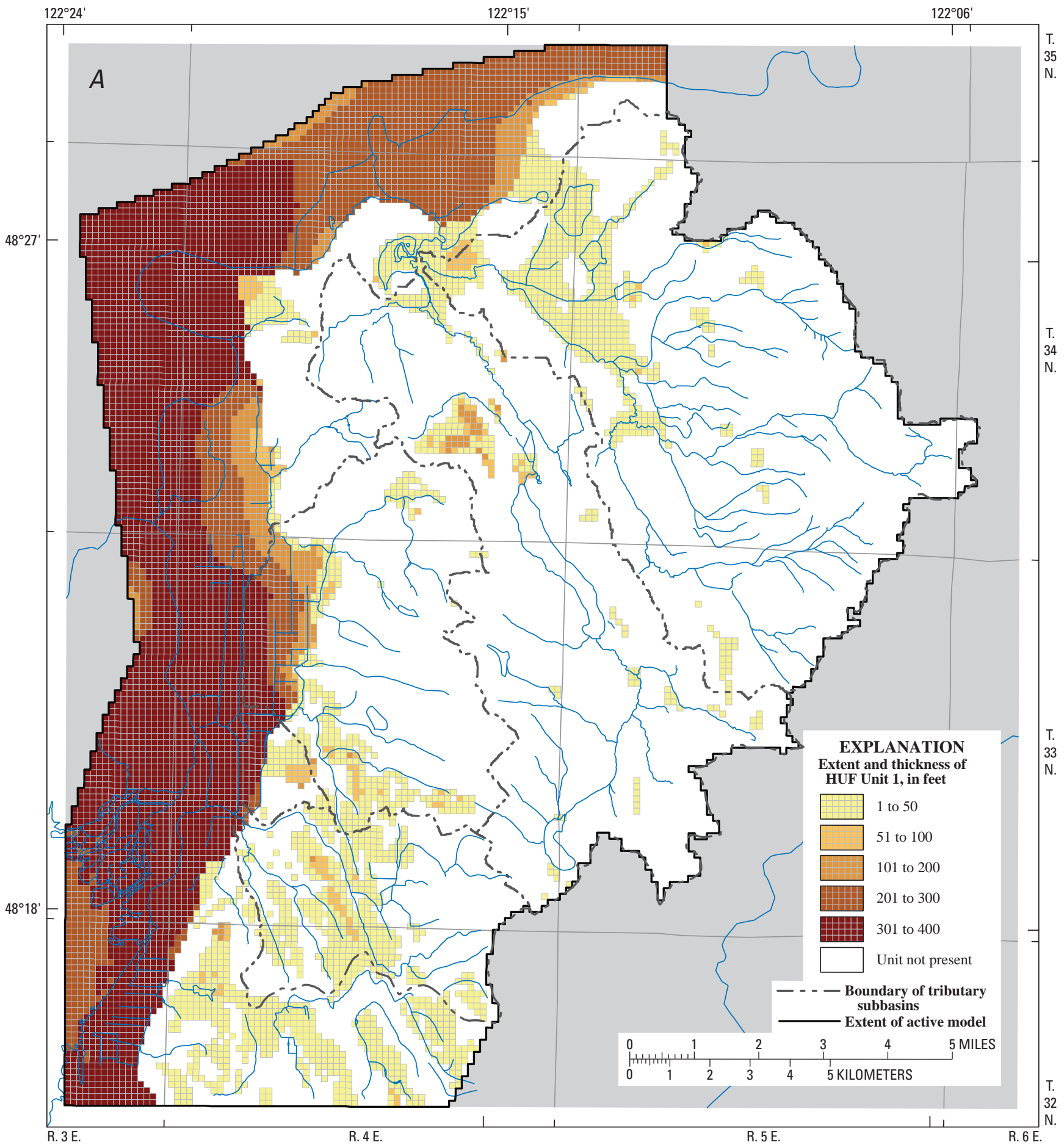

Figure 3. Extent and thickness of hydrogeologic units simulated with the Hydrogeologic-Unit Flow package, tributary subbasins and vicinity, lower Skagit River basin, Washington. 


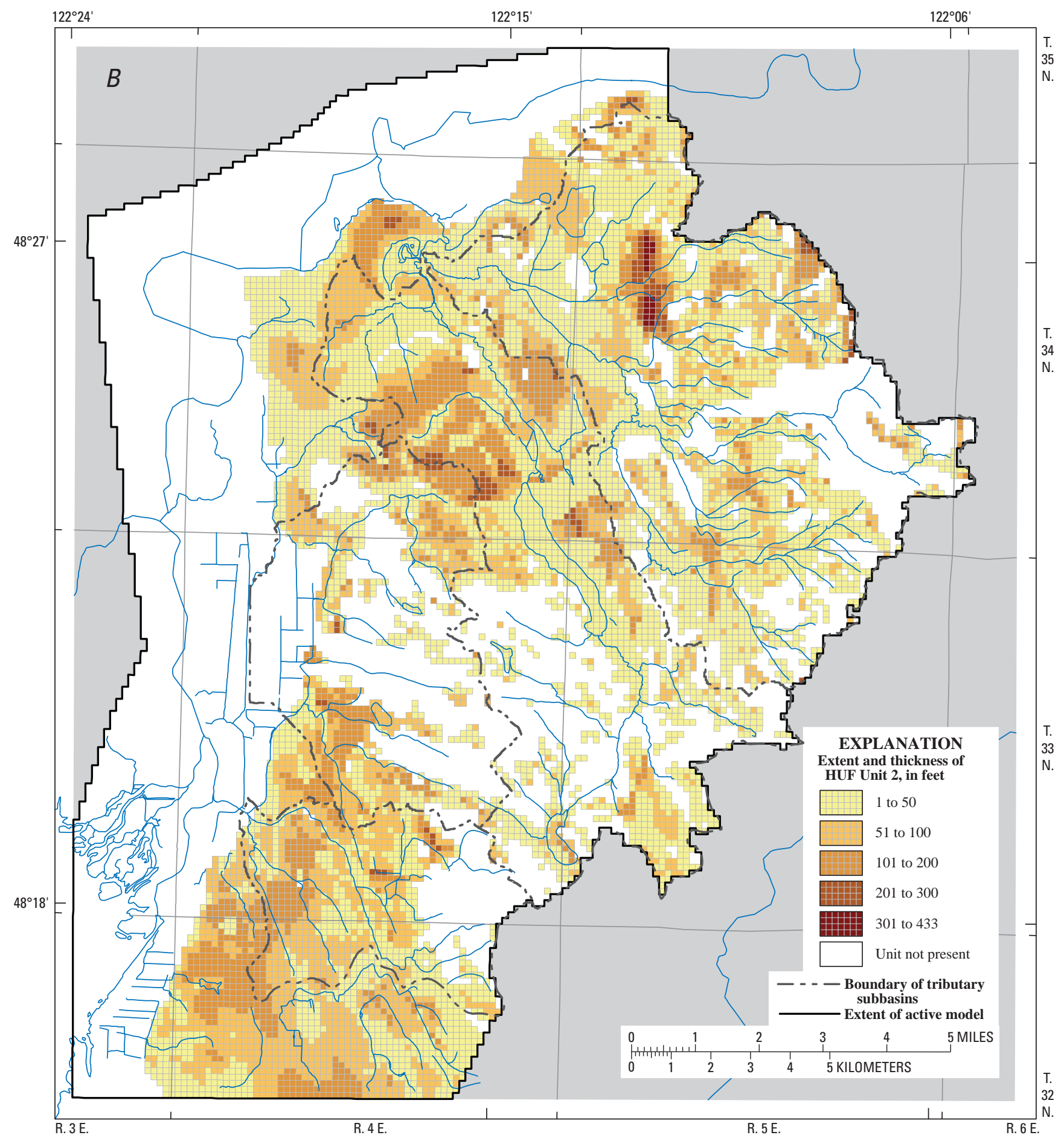

Figure 3.-Continued 


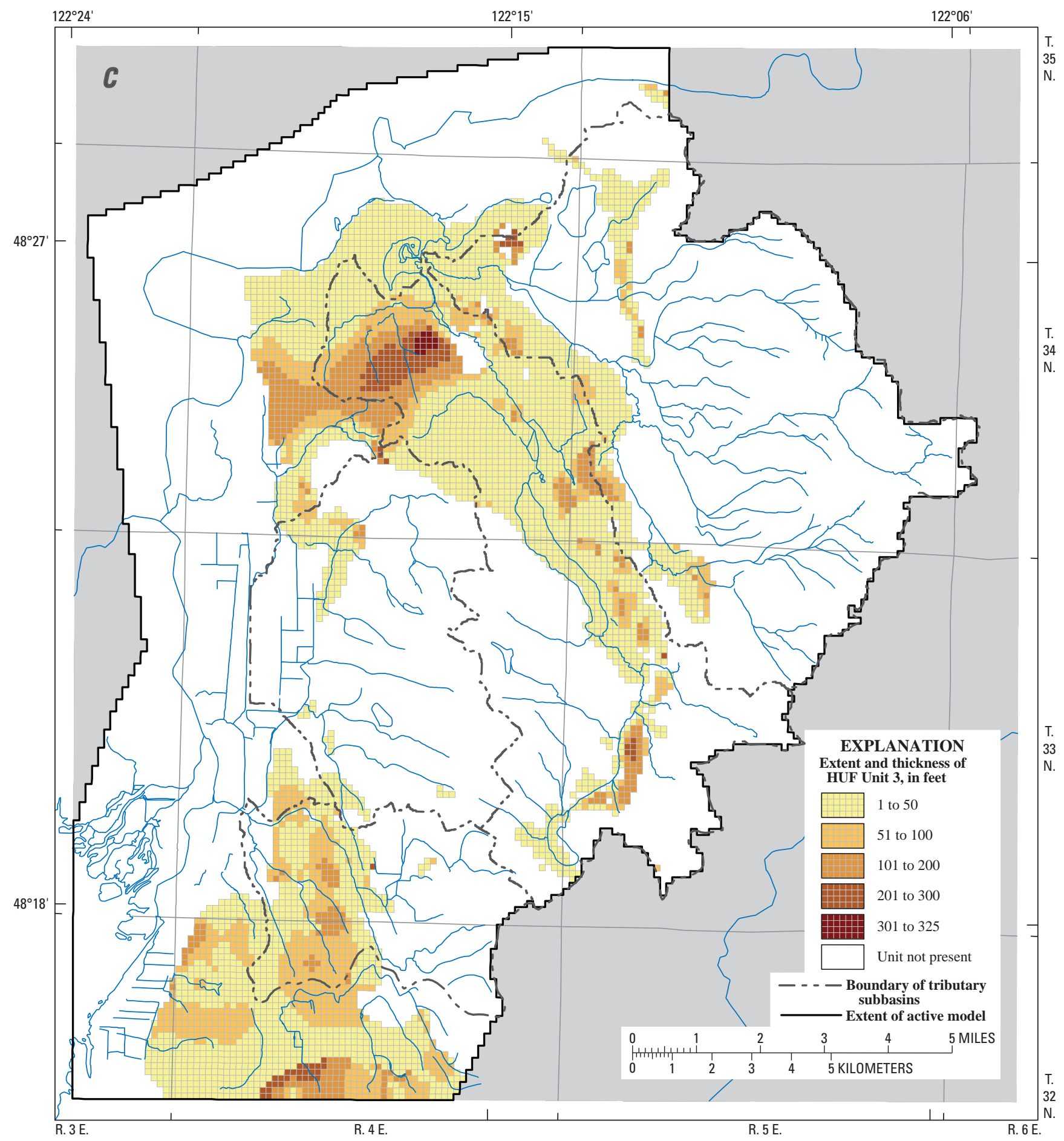

Figure 3.-Continued 


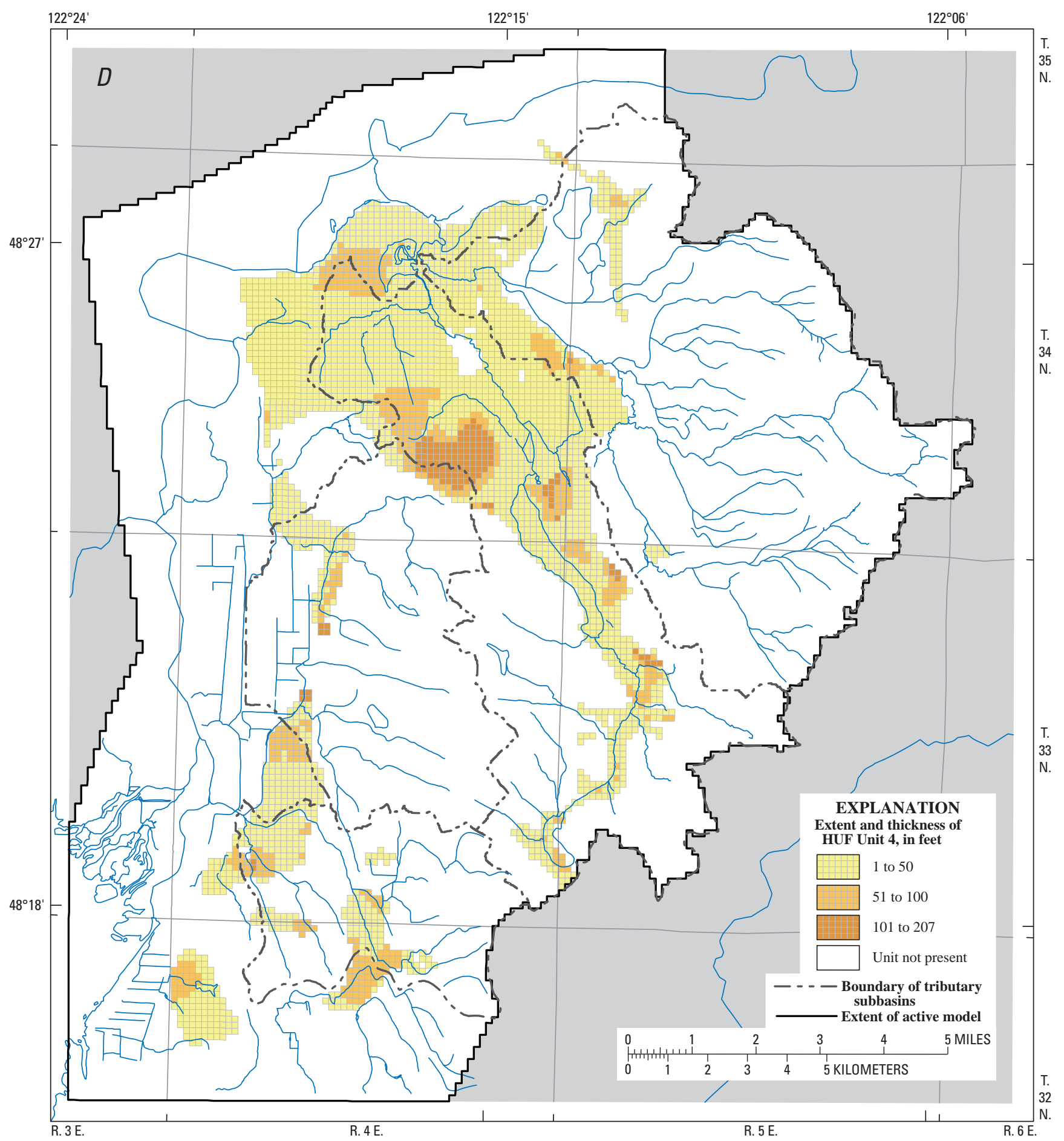

Figure 3.-Continued 


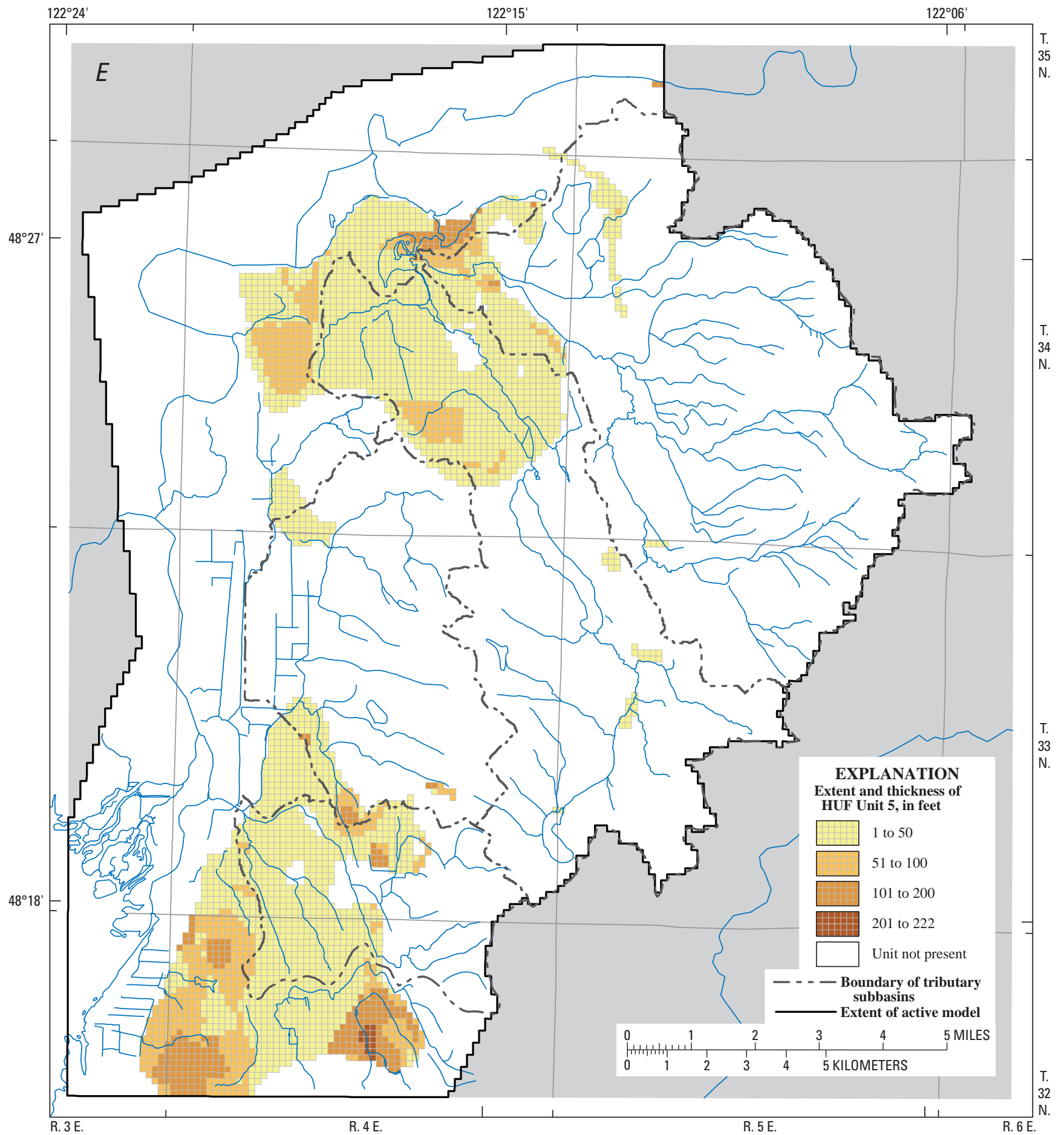

Figure 3.-Continued 


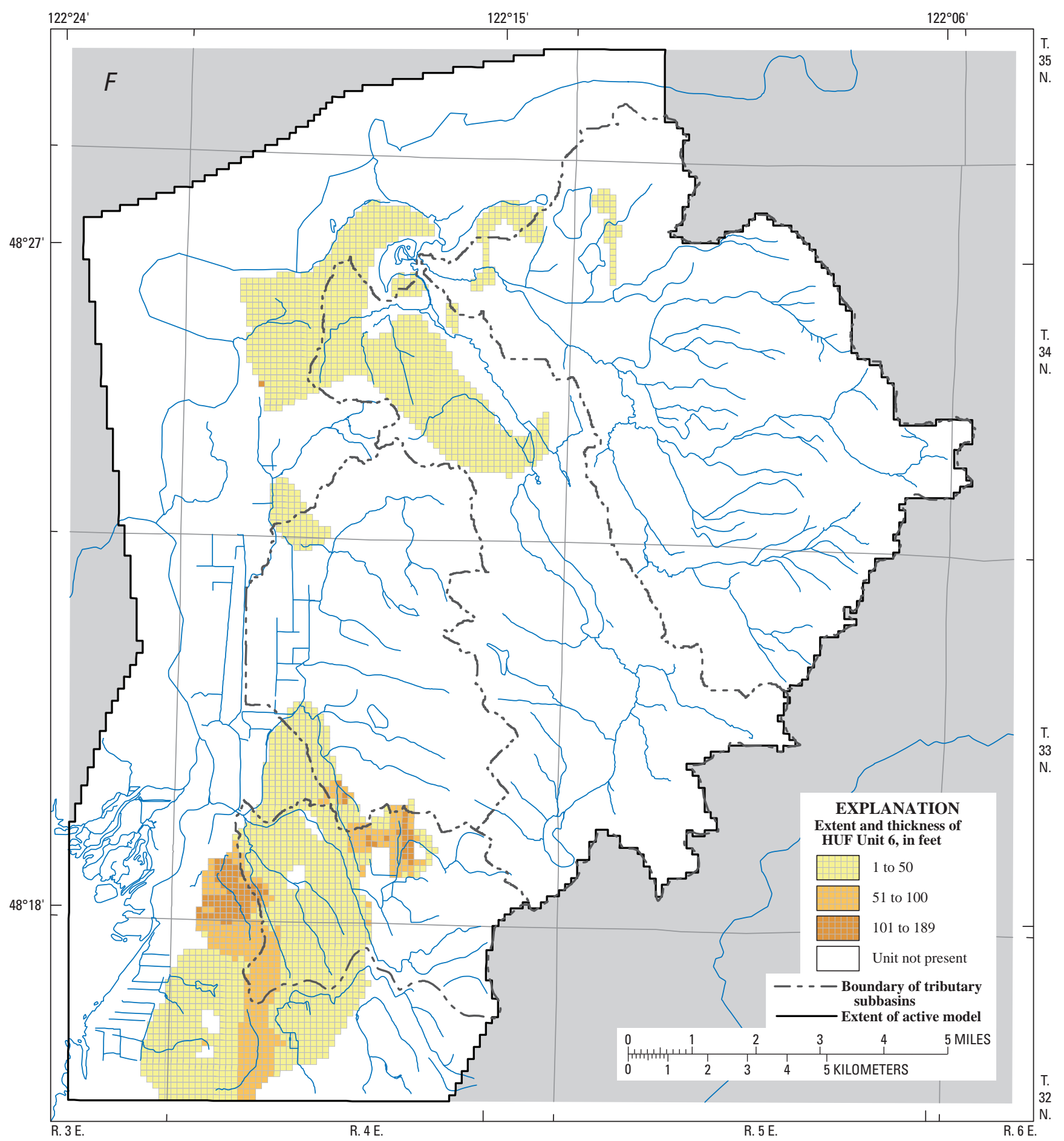

Figure 3.-Continued 


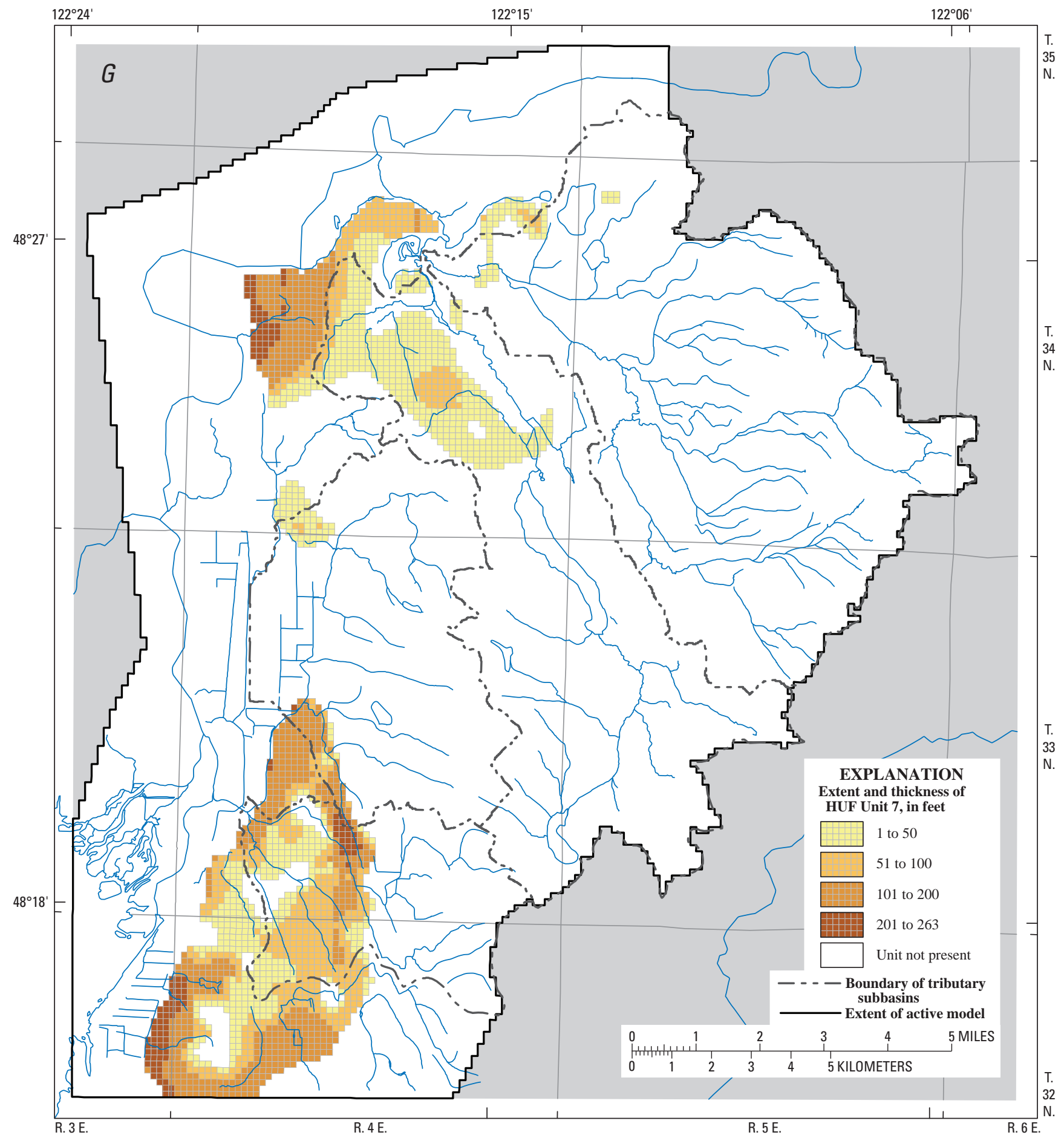

Figure 3.-Continued 


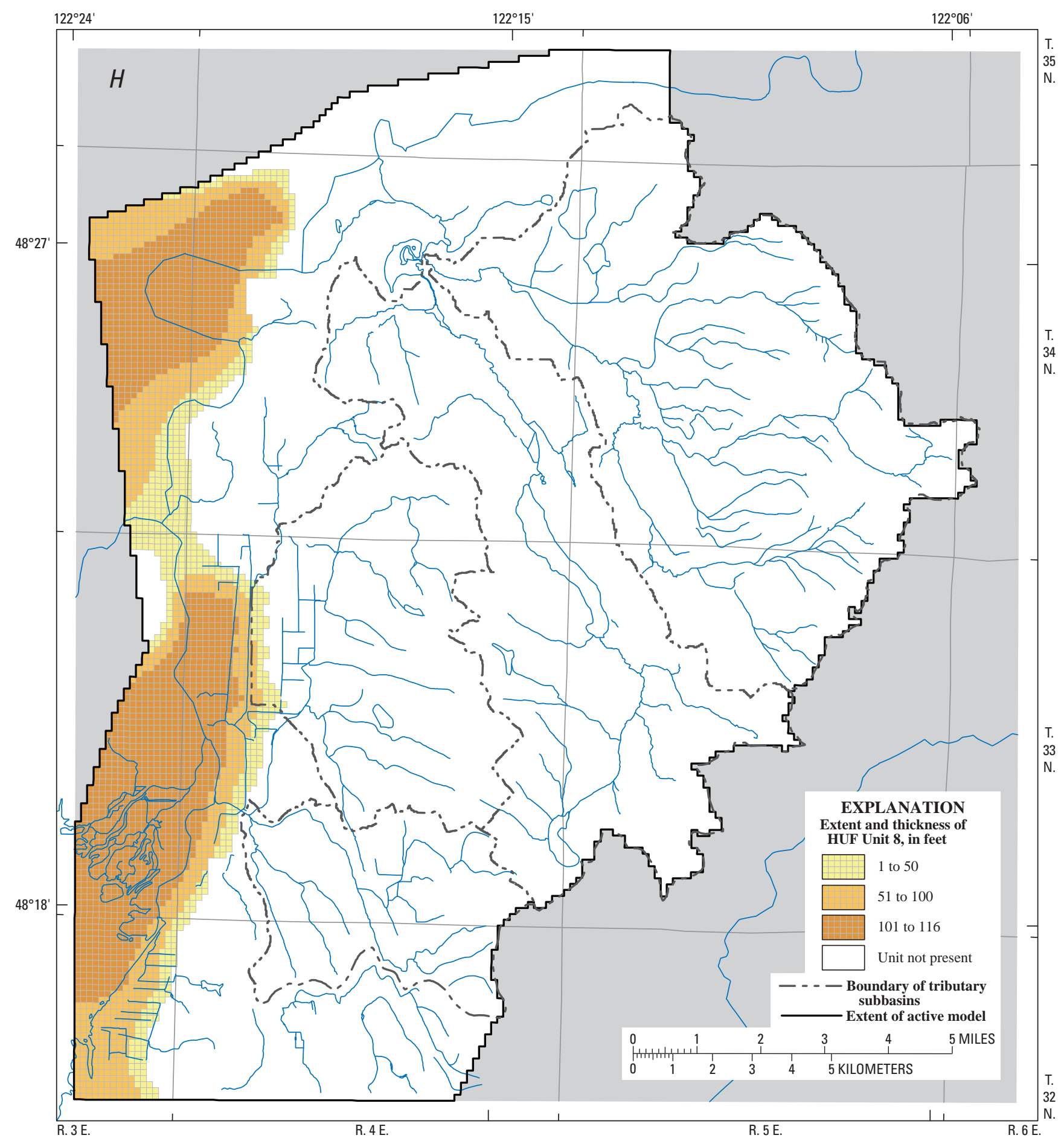

Figure 3.-Continued 


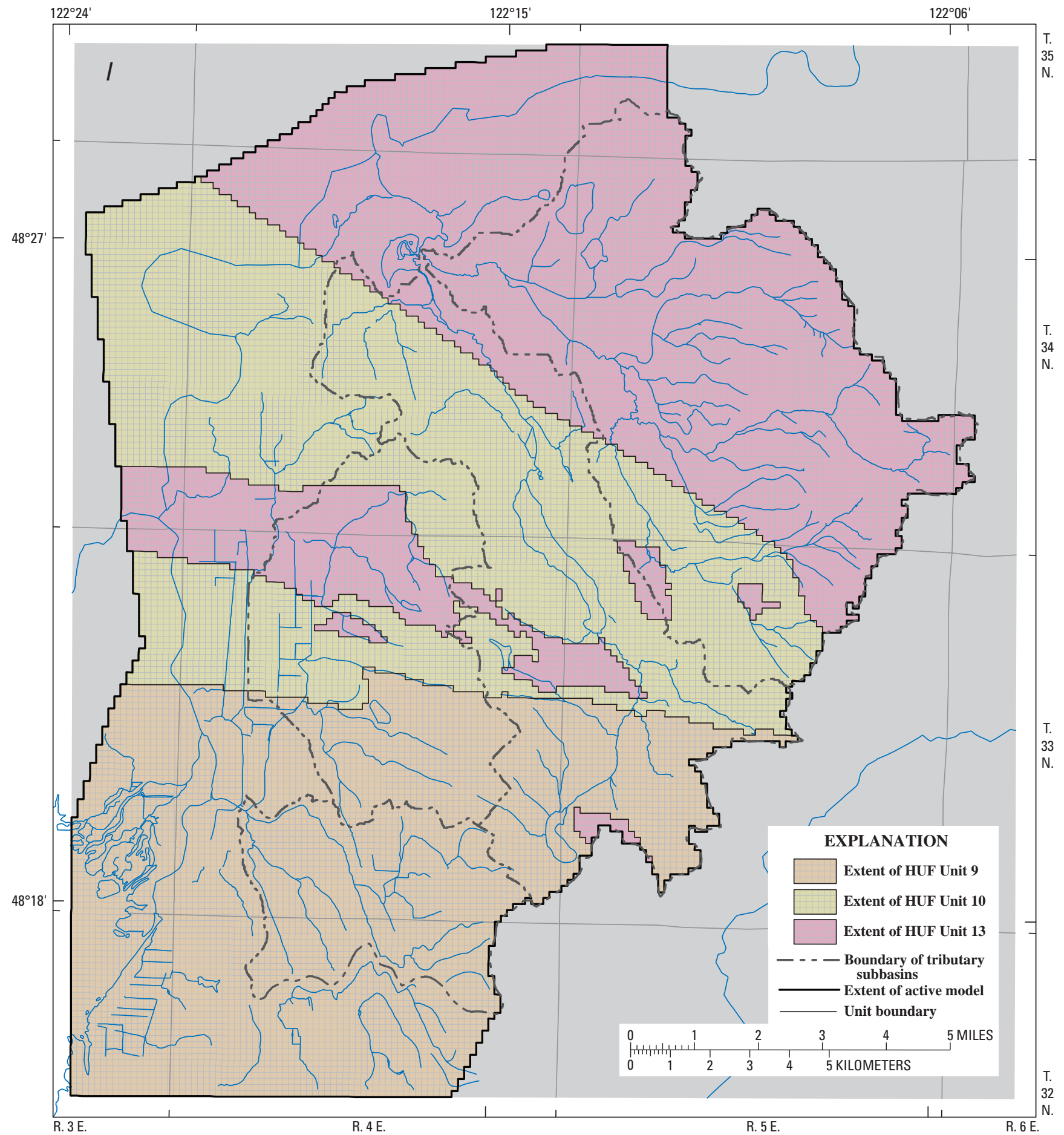

Figure 3.-Continued 

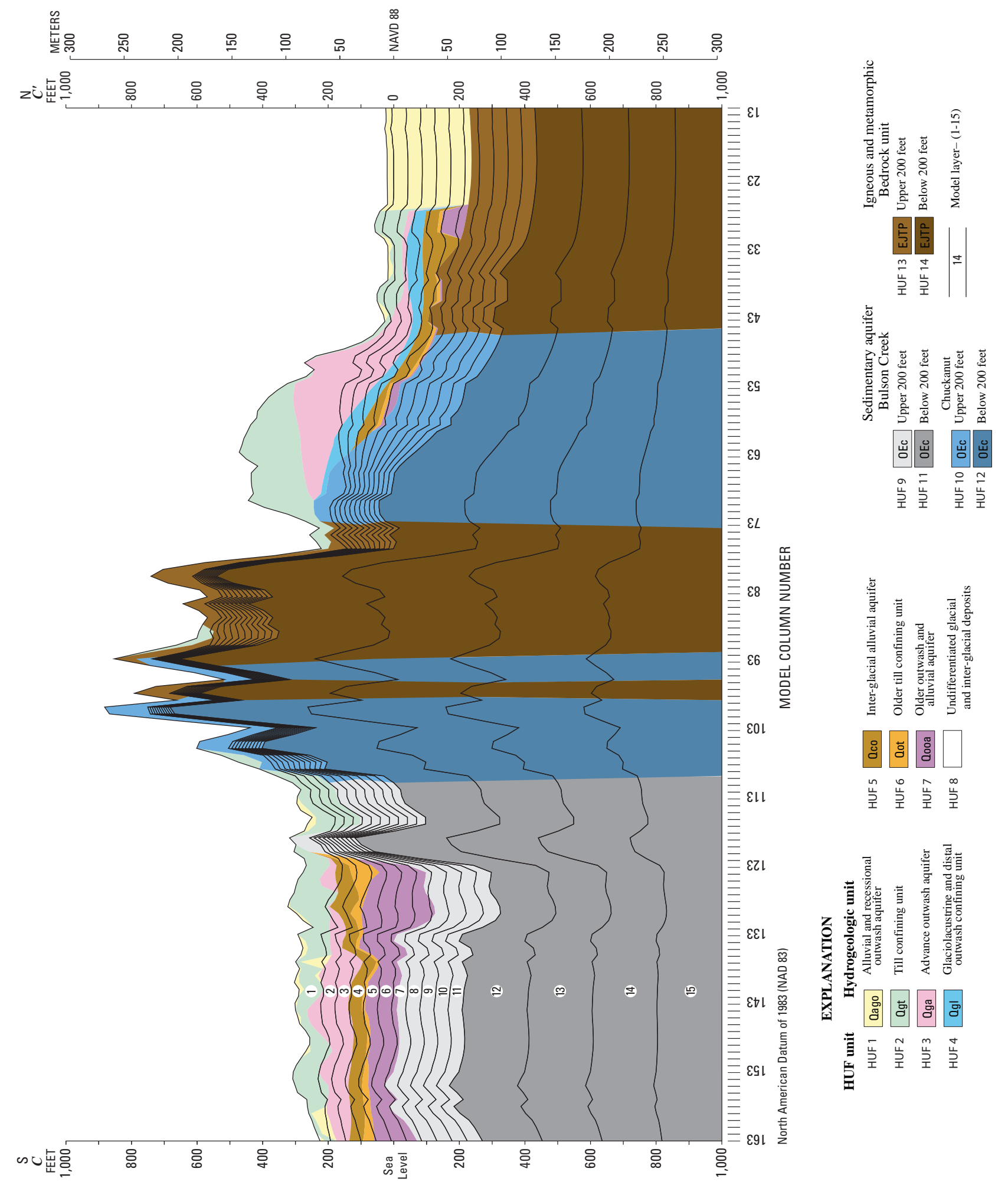

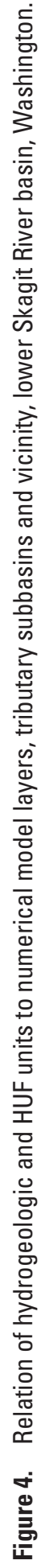




\section{Hydraulic Conductivity}

Initial values of horizontal hydraulic conductivity for the HUF units (table 3) were based on analyses of specific-capacity data (Savoca and others, 2009a). Because there is no evidence to suggest horizontal hydraulic conductivity varies with direction (no preferential flow), horizontal isotropy was assumed $\left(K_{x}=K_{y}\right)$. Initial values of horizontal hydraulic conductivity in aquifer units ranged from $0.05 \mathrm{ft} / \mathrm{d}$ in the deeper part of the sedimentary aquifer (HUF12) to $48 \mathrm{ft} / \mathrm{d}$ in the advance outwash aquifer (HUF3). Initial values of horizontal hydraulic conductivity in confining and bedrock units ranged from $0.007 \mathrm{ft} / \mathrm{d}$ in the deeper part of the igneous and metamorphic bedrock unit (HUF14) to $1.5 \mathrm{ft} / \mathrm{d}$ in the till confining unit (HUF2). Undifferentiated glacial and inter-glacial deposits (HUF8) were simulated using an initial horizontal hydraulic conductivity value of $6 \mathrm{ft} / \mathrm{d}$. Initial values of horizontal hydraulic conductivity were modified during model calibration.

Initial values of vertical hydraulic conductivity were assigned to each HUF unit (table 3) as the ratio of horizontal to vertical hydraulic conductivity (vertical anisotropy). Assignment of vertical anisotropy to HUF units was based on unit lithologic and hydraulic characteristics.

- Unconsolidated aquifers consisting primarily of well sorted sand and gravel (HUF units 1, 3, 5, and 7) were assigned a vertical anisotropy of 10 (that is, $K_{x}=K_{y}=$ $\left.10 \times K_{z}\right)$;

- Unconsolidated confining units consisting primarily of poorly sorted and fine-grained deposits (HUF units 2, 4 , and 6) were assigned a vertical anisotropy of 100.

- Undifferentiated glacial and inter-glacial deposits inferred at depths greater than approximately $300 \mathrm{ft}$ below sea level in the Skagit River valley (HUF unit 8) represent a composite of probable aquifers and intervening confining units and were assigned a vertical anisotropy of 30 that represents an intermediate value between an unconsolidated aquifer and confining unit.

- The shallower part (upper $200 \mathrm{ft}$ of unit thickness) of the sedimentary aquifer (HUF units 9 and 10) was assigned a vertical anisotropy of 0.1 (rather than a value of 10 for unconsolidated aquifers) to account for an assumed greater flow along subvertical secondary permeability features (joints and fractures).

- The shallower part (upper $200 \mathrm{ft}$ of unit thickness) of the igneous and metamorphic bedrock Unit (HUF unit 13) was considered to be isotropic $\left(K_{x}=K_{y}=K_{z}\right)$ due to preferential groundwater movement in both vertical and horizontal directions along subvertical secondary permeability features (joints and fractures), and a general lack of primary porosity within the rock matrix.
- The deeper part (greater than $200 \mathrm{ft}$ ) of the sedimentary aquifer (HUF units 11 and 12) and igneous and metamorphic bedrock unit (HUF unit 14) were considered to be isotropic to account for an assumed reduction or elimination of groundwater movement along secondary permeability features, and the reduction of primary porosity due to compressive forces.

\section{Specific Storage}

Specific storage values are assigned to model cells to represent the change in groundwater storage that results from expansion and contraction of the unit matrix and the water in a confined aquifer. Both unconfined and confined conditions occur within the groundwater system; however, in order to prevent the drying of model cells, and resultant model instability, specific storage values were assigned to cells simulating both unconfined and confined conditions. Initial specific storage values for aquifer units (table 3 ) ranged from $1.0 \times 10^{-4} \mathrm{ft}^{-1}$ in the deeper part (greater than $200 \mathrm{ft}$ ) of the sedimentary aquifer (HUF units 11 and 12) to $0.15 \mathrm{ft}^{-1}$ in the alluvial and recessional and advance outwash aquifers (HUF units 1 and 3, respectively). Initial specific storage values for confining and bedrock units ranged from $1.0 \times 10^{-4} \mathrm{ft}^{-1}$ in the deeper part of the igneous and metamorphic bedrock unit (HUF14) to $0.15 \mathrm{ft}^{-1}$ in the till confining unit (HUF2). Undifferentiated glacial and inter-glacial deposits (HUF8) were simulated using an initial specific storage value of $0.05 \mathrm{ft}^{-1}$. Initial values of specific storage were modified during model calibration.

\section{Boundary Conditions and Implementation of MODFLOW Packages}

Specified-flux and head-dependent flux boundaries were used to represent hydrologic boundaries in the model. These boundaries define the physical limits of the model and simulate recharge to and discharge from the groundwater system. Specified-flux boundaries allow a specified rate of water to flow across the model boundary and are used to simulate much of the inflow into the model, for example precipitation-driven recharge, and some of the discharge out of the model, such as groundwater withdrawals from pumping wells. Head-dependent flux boundaries simulate flow across the boundary proportional to the difference in heads across the model boundary and are used to simulate most of the discharge and some of the sources of inflow to the model, (for example groundwater-flow to and from the Skagit Delta area). Specified-flux and head-dependent flux boundaries are implemented in the model using various MODFLOW packages and are described in the following subsections. 
No-flow boundaries are specified-flux boundaries with flux equal to zero - no groundwater flow is simulated across these boundaries. No-flow boundary conditions are implicitly specified along the bottom of the model domain (bottom of model layer 15) and beyond the first and last row or column of model cells (extent of active model). No-flow boundary conditions occur: (1) along the northern, southern, and southwestern (north of Skagit Bay) extent of the active model where groundwater-flow directions are sub-parallel to model boundaries; (2) along the eastern extent of the active model along the crest of a sedimentary and bedrock topographic divide; and (3) along a portion of the extent of the active model within Skagit Bay.

\section{Recharge Package}

The Recharge Package was used to simulate groundwater recharge from precipitation, and return flows from septic systems and outdoor (irrigation) use. Recharge (in units of feet per day) is applied as a specified flux to the uppermost active cell. Precipitation is the dominant source of water recharging the groundwater system in the study area, and variations in recharge are related to spatial and temporal variations in precipitation, the permeability of surficial hydrogeologic units, and land-cover characteristics. The distribution of recharge from precipitation in the study area was estimated by applying precipitation-recharge relations (Savoca and others, 2009a) based on regression equations developed for areas in Puget Sound, Washington (Bidlake and Payne, 2001) that incorporate the effects of surficial hydrogeology and tree canopy characteristics. The effects of impervious surfaces on the distribution of recharge from precipitation also were estimated in urban portions of the study area. The groundwater system within the subbasins received an average (September 1, 2006-August 31, 2008) of about 92,400 acre-ft or about 18 in. of recharge from precipitation a year (Savoca and others, 2009a).

Return flows were simulated as a percentage of the water used at residences with septic systems. A total returnflow rate (indoor and outdoor use) of 76 percent was used in the steady-state model, and closely correlates with total return-flow rates used in other groundwater studies in western Washington (Sapik and others, 1987; Drost and others, 1999; van Heeswijk and Smith, 2002; Geoengineers, 2003). The steady-state return-flow estimate (173 gal/d per connection) is based on a typical per connection water-use rate of $228 \mathrm{gal} / \mathrm{d}$ (Savoca and others, 2009a). Return-flow estimates used in the transient model account for temporal variations in outdoor use. During the winter months (October through April) outdoor use (lawn and garden irrigation) is assumed to be zero. Therefore, water use during the winter is entirely for indoor use, and an indoor return-flow rate of 87 percent was used to simulate septic-system return flows during the winter. This indoor (winter) return-flow rate is similar to the winter rate used in a nearby groundwater study (Geoengineers, 2003). The indoor return-flow estimate ( $150 \mathrm{gal} / \mathrm{d}$ per connection) used in the transient model is based on a per connection indoor water-use rate estimate of $173 \mathrm{gal} / \mathrm{d}$ that was derived from an analysis of reported Public Water System pumpage data for Pierce County, Washington.

An outdoor use return-flow rate of 40 percent was used in the transient model to simulate lawn and garden irrigation return flows during the summer months (May-September). A similar outdoor use return-flow rate was recently used in a groundwater study in eastern Washington (Hsieh and others, 2007), and a quantitative field study of consumptive use associated with lawn watering by Oad and others (1997) estimates an efficiency of 60 percent and deep percolation of 40 percent of applied lawn water. Several methods have been used to determine return-flow rates associated with lawn and garden irrigation resulting in a wide range of published return-flow rate values (Oad and DiSpigno, 1997). These return-flow rates are based on studies representing conditions that may not be descriptive of conditions in the tributary subbasins model area. Lawn and garden irrigation return-flow rates may vary spatially in the model area, and the return-flow rate used in the model is an approximation based on limited data. The temporal distribution of return flow in the transient model (fig. 7A) was based on an analysis of monthly Public Water System pumpage data for Pierce County, Washington, conducted by the USGS (Ron Lane, written commun., 2009).

The return flows were spatially distributed to cells according to the number of residences in each cell that had septic systems. Locations of residences were based on the centers of tax parcels, as obtained from County Assessor offices, and specifically those parcels that were reported as having improvements (the number of housing units derived this way agrees with Census 2000 data for Block Group totals). Excluded from the recharge were those parcels that were located in the City of Mount Vernon or in the boundaries of Skagit County Sewer District No. 2. The distribution of septic systems was confirmed and adjusted by a mapping of known septic systems that was developed by the Skagit County Public Health Department. The distribution of recharge is shown in figure 5 in terms of average annual total recharge (precipitation and return flows), and the amount of this recharge that is attributed to return flows (septic and outdoor use) is shown in figure 6.

The temporal discretization of monthly recharge (precipitation recharge and residential return flows) used in the transient model is shown in figure $7 \mathrm{~A}$ as factors that increase or decrease the values used in the steady-state model. During the winter (October-April), a constant return flow rate (173 gal/d per connection) was used to reflect primarily indoor water use during the winter months. In the summer (May-September) precipitation recharge decreases, and increased residential withdrawals (due to increased outdoor water use) result in increased residential return flows that peak (232 gal/d per connection) in July. 


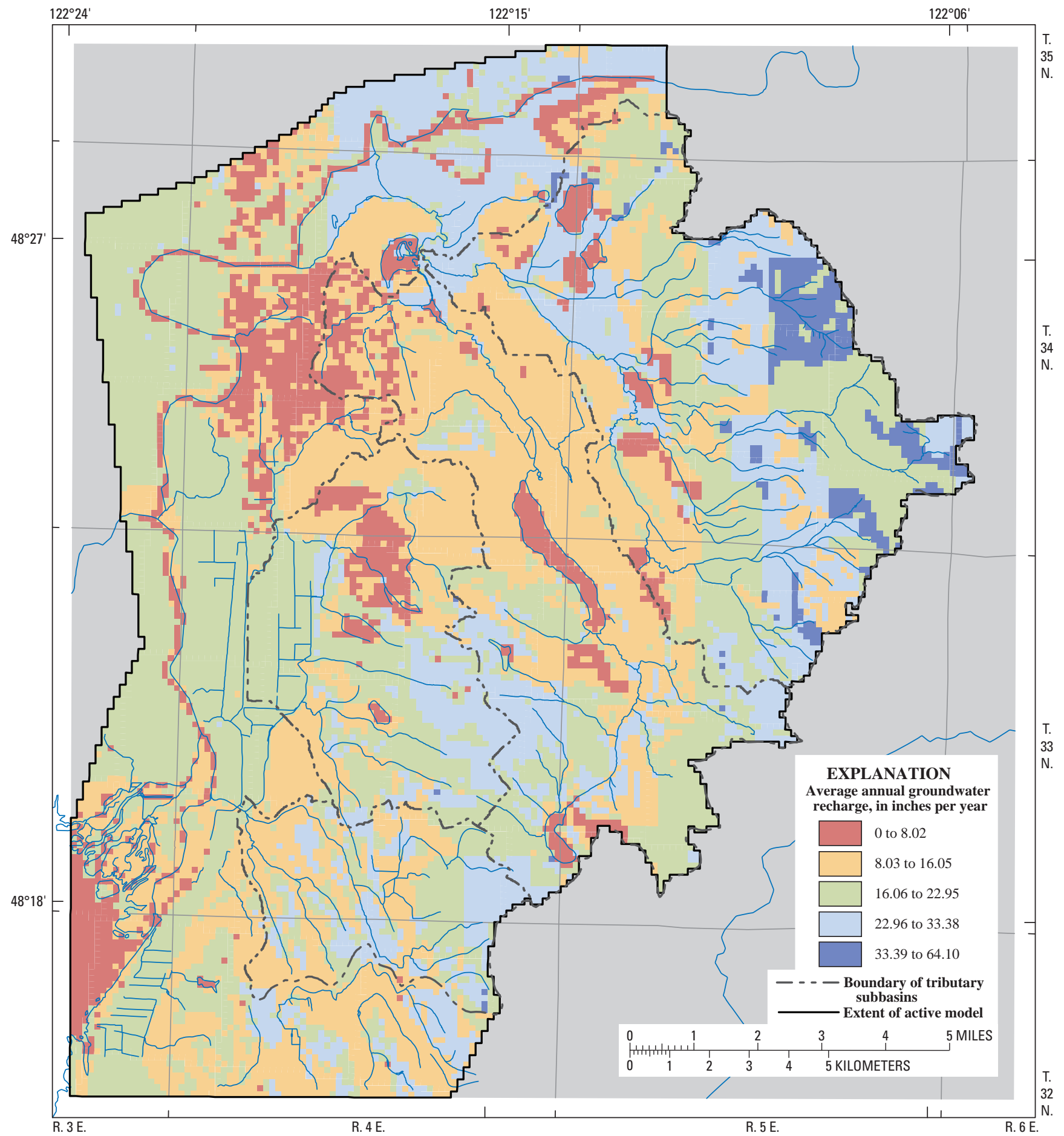

Figure 5. Distribution of average annual total groundwater recharge from precipitation and return flow in tributary subbasins and vicinity, lower Skagit River basin, Washington, September 2006-September 2008. 


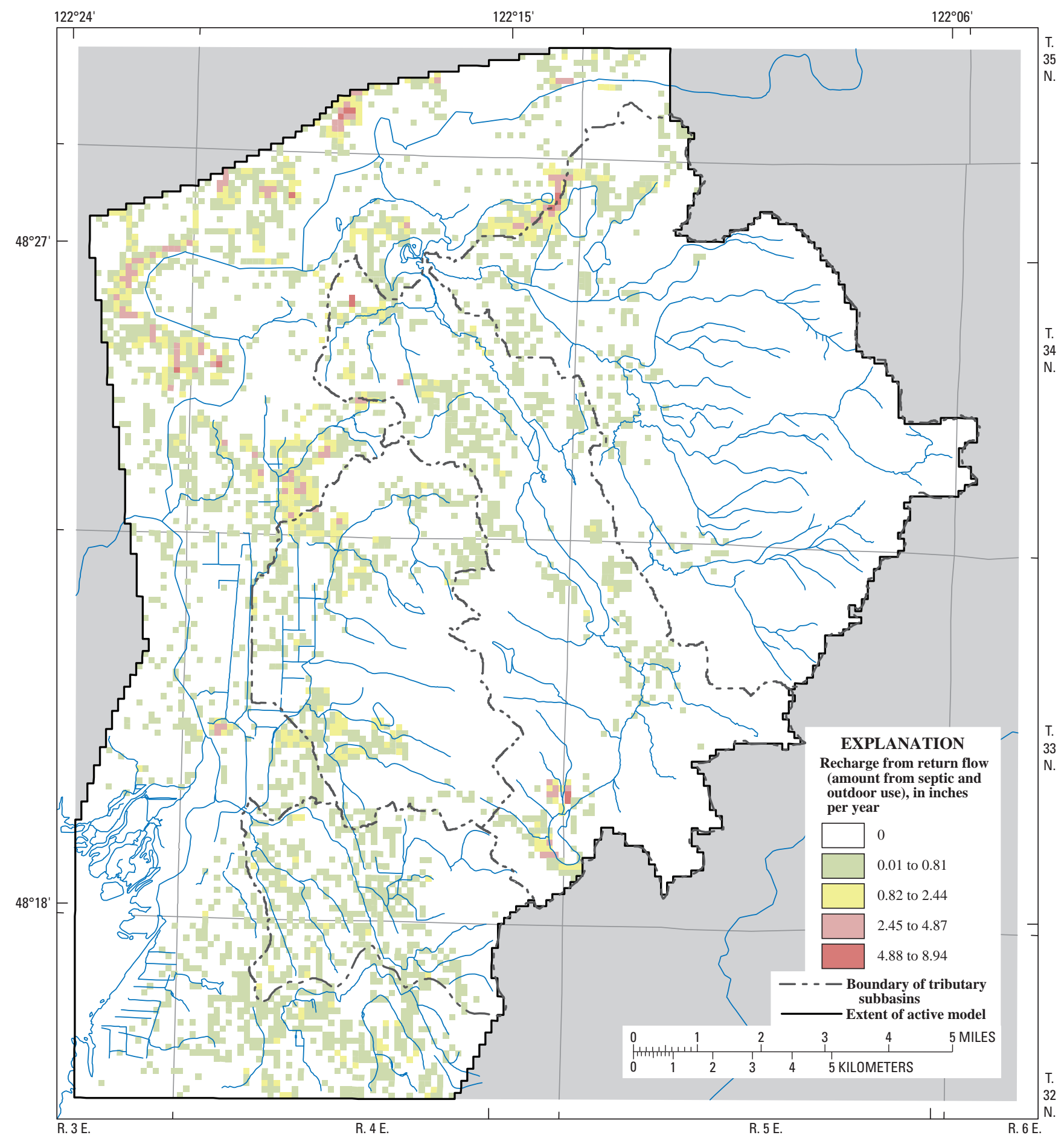

Figure 6. Distribution of average annual groundwater recharge from return flow (septic and outdoor use) in tributary subbasins and vicinity, lower Skagit River basin, Washington, September 2006-September 2008. 

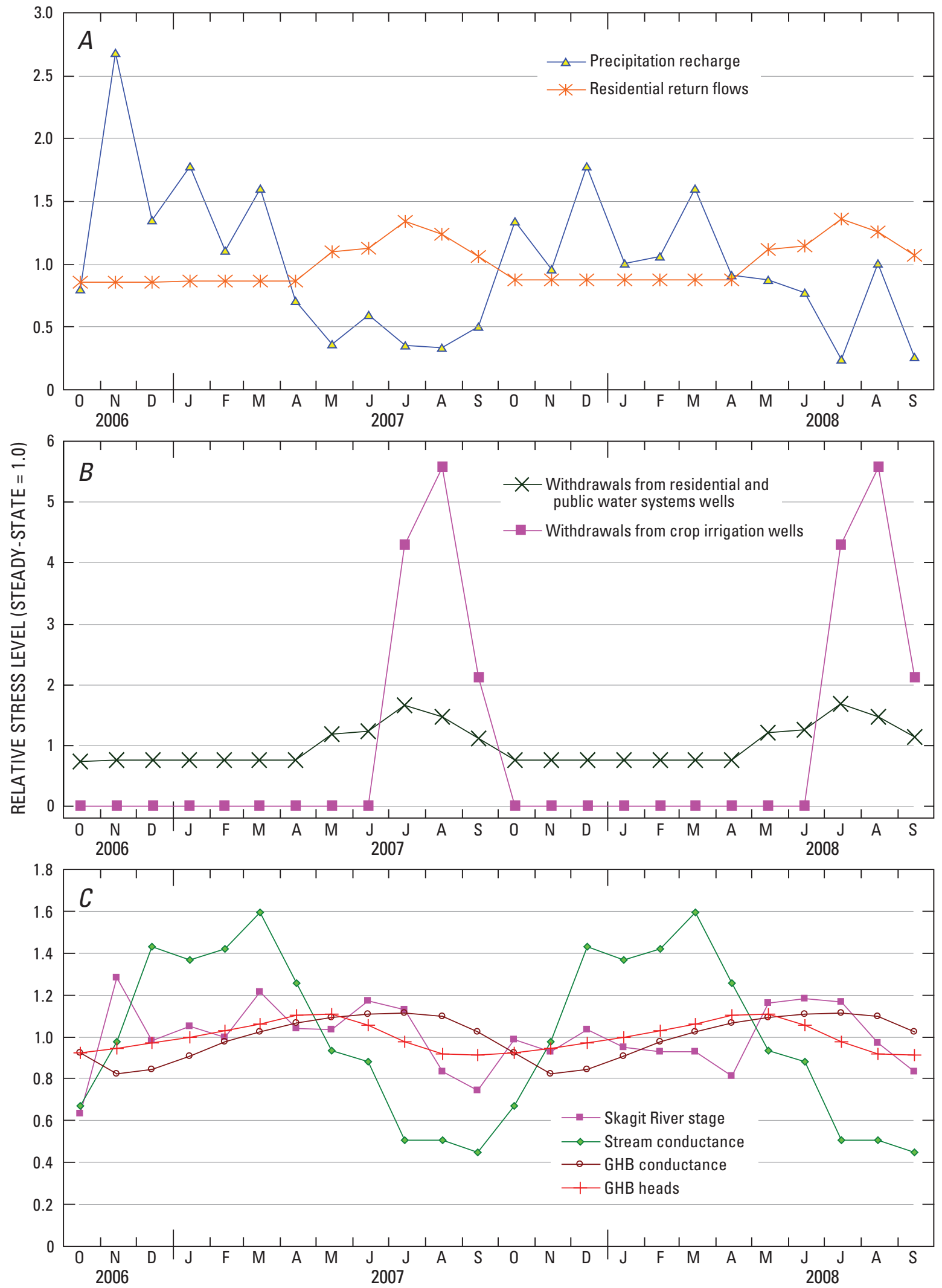

Figure 7. Temporal discretization of selected model values, tributary subbasins and vicinity, lower Skagit River basin, Washington, September 2006-September 2008. 


\section{Well Package}

The Well Package was used to simulate groundwater withdrawals from pumping wells. The Well Package simulates a specified-flux boundary in each model cell to which a well is assigned based on the withdrawal rate for each well or group of pumping wells located in the cell. Withdrawals (in units of cubic feet per day) were specified for each monthly stress period (fig. 7B). The distribution of withdrawal among model layers was based on the reported (public supply wells) or estimated (domestic and crop irrigation wells) depth of the open interval of the well, and the hydrogeologic framework from Savoca and others (2009a). Public-supply well withdrawals were assigned to HUF units using well construction records (depth of open interval) to identify the corresponding HUF unit in the hydrogeologic framework. Domestic and irrigation well withdrawals were assigned to HUF units based on assumptions about open interval depths and knowledge of the subsurface distribution of aquifers and confining units. Most domestic and irrigation wells in the study area were assumed to withdraw water from the first reliable source of water encountered during well drilling; typically the advance outwash aquifer (HUF unit 3 ) where it is present. This assumption is supported by the inventory of well records conducted by Savoca and others (2009a) in which most wells in the study area were open to the advance outwash aquifer. Therefore, domestic and irrigation well withdrawals were assigned to HUF unit 3, if present, otherwise in decreasing order of preference HUF units 1, 5, or 7, according to which was sufficiently thick and nearest to the surface. If none of the unconsolidated aquifers were present beneath the model cell containing the well, one of the shallower confining units (HUF units 2, 4, 6) or the uppermost sedimentary or bedrock unit (HUF units 9, 10, or 13) was used. Because a well has to be input according to the model layer, rather than a HUF unit, the altitude of the center of the assigned HUF unit was used to identify the appropriate model layer.

Groundwater withdrawals from wells in the tributary subbasins in 2008 were an estimated 2,200 acre-ft (Savoca and others, 2009a). Public supply and domestic groundwater withdrawals were estimated using a typical water-use rate of $228 \mathrm{gal} / \mathrm{d}$ per connection. The typical use rate was estimated by multiplying a per-capita water-use rate of $84 \mathrm{gal} / \mathrm{d}$ (Lane, 2009) by an estimate of 2.71 people per connection (U.S. Census Bureau, 2000). Well withdrawals in the transient model were multiplied by a monthly factor to account for year-round indoor use of about $173 \mathrm{gal} / \mathrm{d}$ per connection, and summertime outdoor water use that reaches a maximum of about $204 \mathrm{gal} / \mathrm{d}$ per connection in July (fig. 7B). The number and spatial distribution of connections in the study area (fig. 2) was estimated using the Skagit and Snohomish County assessor databases, and the Washington State Department of Health database (Skagit County, 2008; Snohomish County, 2008; Washington State Department of Health, 2008). Crop irrigation withdrawals (fig. 2 and $\underline{7 B}$ ) were estimated by multiplying crop specific application rates by the number of acres under production within the tributary subbasins for each crop type, and then accounting for irrigation method efficiency (U.S. Department of Agriculture, 2007; Washington State Department of Agriculture, 2008).

\section{River Package}

The River Package was used to simulate the exchange of water between streams and the aquifer system. In the River Package, a river reach refers to the section of a river within a model cell. For a river reach, the volumetric flow rate across the riverbed to the underlying model cell is computed as

$$
Q_{r b}=C_{r b}\left(h_{r}-h_{a}\right)
$$

where

$$
\begin{aligned}
& Q_{r b} \text { is the flow rate across the riverbed }\left(\mathrm{ft}^{3} /\right. \text { day), } \\
& C_{r b} \text { is the conductance of the riverbed }\left(\mathrm{ft}^{2} /\right. \text { day), } \\
& h_{r} \text { is the river stage ( } \mathrm{ft} \text { ), and } \\
& h_{a} \text { is the hydraulic head ( } \mathrm{ft} \text { ) in the cell } \\
& \text { underlying the riverbed when the bottom } \\
& \text { of the riverbed is below the water table; } \\
& \text { or } h_{a} \text { is the altitude of the bottom of the } \\
& \text { riverbed ( } \mathrm{ft} \text { ) when the bottom of the } \\
& \text { riverbed is above the water table in the cell. }
\end{aligned}
$$

The conductance of the riverbed is given by

$$
C_{r b}=K_{v} w L / m,
$$

where

$$
\begin{aligned}
& K_{v} \text { is the vertical hydraulic conductivity of the } \\
& \text { riverbed sediment ( } \mathrm{ft} / \text { day), } \\
& w \text { is the width of the river reach, } \\
& L \text { is the length of the river reach, and } \\
& m \text { is the thickness of the riverbed sediment (ft). }
\end{aligned}
$$

However, $K_{v}, w, L$, and $m$ are not individually specified in the River Package. Instead, conductance of the riverbed, $C_{r b}$, is specified. Model cells used in the River Package are shown in figure 2. 
River stage (water-surface altitude) was estimated using LiDAR derived altitudes along river channels. Riverbed conductance varied with the vertical hydraulic conductivity of the hydrogeologic unit underlying each river reach (Savoca and others, 2009a). The area (length times width) of a river within a model cell was calculated by summing area calculations for the short line segments in that cell, as derived by GIS methods from the river channel shape file. The width of the stream channel at any point was estimated as a function of the total length of channel upstream of the point (a measure of drainage area), based on stream crosssection measurements at stream gages and stream baseflow measurement sites (Savoca and others, 2009a). The thickness of the streambed at any point was estimated as a function of the depth of the stream at the point, based on stream depth measurements at gage and baseflow sites (Savoca and others, 2009a). The conductances of all stream channels in a model cell were summed to get the total river conductance for that cell; river stage in the cell was based on the average of LiDAR-derived altitudes for the stream points in the cell. Drainage ditches in the Skagit River valley were simulated using a width of $5 \mathrm{ft}$ and a length equivalent to the model cell $(500 \mathrm{ft})$. In the transient model, the widths of streams (except the Skagit River) were estimated to vary seasonally according to variations in streamflows measured at stream gage sites, and stream conductance values were adjusted during model calibration by a monthly factor (fig. 7C) to reflect temporal changes in stream width. Temporal changes in stream depth also were adjusted by the same factor.

River stage in Skagit River and its distributaries, the North and South Forks, were represented in the model using the linear river stage gradient from Savoca and others, (2009b). An average river stage gradient was assigned to the Skagit River for the steady-state period; monthly river stage gradient values were assigned to the Skagit River during the transient simulation period (fig. 7C) according to measured monthly average water levels at the gage (Savoca and others, 2009b). The width and depth of the Skagit River were based on records at the gage and from flow studies conducted near the confluence of the distributaries (Curran, written commun., 2010).

Lakes also were simulated in the model using river boundary conditions. The area in each cell occupied by a lake was estimated, and a hydraulic conductivity value was assigned to the lake bed based on the hydraulic properties of the HUF unit present at that altitude. Because the water-level altitudes in lakes were known to be controlled, water levels in lakes were kept constant during the transient simulation period. The length of the steady-state period, and the use of monthly transient time steps precluded simulation of daily tidal effects in the model; therefore, a water surface altitude value of zero (sea level) was assigned to Skagit Bay for both the steady-state and transient models. Model cells that extend out into the tidal flats of Skagit Bay also were simulated using river boundary conditions. For the reasons mentioned above, daily tidal effects were not simulated in these cells, and water-level altitudes for cells in the tidal flats were derived from the river stage altitudes of the nearest Skagit River cell, reaching mean sea level at the point where the South Fork of the Skagit River reaches open water in Puget Sound (Skagit Bay).

\section{General-Head Boundary Package}

The General-Head Boundary Package is used to simulate groundwater inflow to and outflow across model boundaries. An unquantified amount of groundwater flow out of the model occurs along the northwestern extent of the active model in the Skagit Delta area (Savoca and others 2009b). The General-Head Boundary Package was used as an approximate representation of this conceptualization and is applied to active cells along part of the western extent of model layers 1 and 2 in this area (fig. 2). Groundwater flow into or out of each cell $\left(Q_{b}\right)$ is computed as

$$
Q_{b}=C_{b}\left(h_{b}-h_{a}\right),
$$

where

$C_{b}$ is the boundry conductance $\left(\mathrm{L}^{2} \mathrm{~T}^{-1}\right)$,

$h_{b}$ is the hydraulic head on the outside of the boundary $(L)$, and

$h_{a}$ is the hydraulic head in the model cell $(L)$.

The value of conductance $\left(C_{b}\right)$ at the general head boundary was adjusted during steady-state and transient model calibration to replicate previously observed (Savoca and others, 2009b) average and transient groundwater head and gradient distributions along the model boundary. Input to the General Head Boundary Package (conductance and head values) were allowed to vary seasonally during the transient simulation (fig. 7C), thus the simulated subsurface flows vary between about 250 acre-ft/yr in November 2006 to $360 \mathrm{acre}-\mathrm{ft} / \mathrm{yr}$ in August 2008 along the western extent of the model as simulated water levels within the model domain vary.

\section{Constant-Head Boundary Package}

The Constant Head Boundary Package was used along part of the southwestern extent of the active model in layer 1 to simulate groundwater discharge to Skagit Bay (fig. 2). The use of a constant head boundary establishes a fixed water-level altitude for the model and promotes model stability. Constant head cells were assigned a value of zero (sea level) in the steady-state and transient models. 


\section{Model Calibration}

Model calibration is the adjustment of model parameters (such as hydraulic conductivity and storage coefficients) so that the differences (residuals) between measured and simulated quantities (such as water levels and stream baseflows) are minimized with respect to an objective function. This section of the report describes the method used for calibration, the calibration data, and the calibration results. The calibration is assessed by examining how well the simulated quantities fit the measured quantities from previous investigations (Savoca and others, 2009a, 2009b).

\section{Calibration Process}

The parameter estimation program PEST (Doherty, 2005, 2006) was used to calibrate the groundwater-flow model. PEST implements a nonlinear least-squares regression method to estimate model parameters by minimizing the sum of squared weighted residuals:

$$
\Phi=\sum_{i=1}^{N}\left(w_{i} r_{i}\right)^{2}
$$

where

$N$ is the number of measurements, $w_{i}$ is the weight for the $i^{\text {th }}$ measured quantity, and $r_{i}$ is the $i^{\text {th }}$ residual, defined as the $i^{\text {th }}$ measured quantity minus the corresponding $i^{\text {th }}$ simulated quantity.

PEST uses the Gauss-Marquardt-Levenberg method to minimize the sum of squared weighted residuals, $\Phi$, also known as the objective function. Details of this method are given in the PEST user's manual (Doherty, 2005, 2006). The weight, $w_{i}$, reflects the importance of the ith measured quantity on the regression. A measurement with a large $w_{i}$ asserts a large influence on the regression and, therefore, the estimated parameter values. Conversely, a measurement with a small $w_{i}$ asserts a small influence on the regression and estimated parameter values.

A preliminary version of the model was developed using a grid with horizontal cell dimensions of 1,000 by $1,000 \mathrm{ft}$, rather than the 500-ft grid size used for the final model. Model layer thicknesses, HUF unit tops and thicknesses, and boundary conditions were initially developed and tested on the coarse grid and were used in a manual calibration of the model. Then the manually calibrated data were integrated into the final $(500-\mathrm{ft})$ grid configuration. The final model, using the finer, 500-foot grid, was then calibrated using PEST and was used to generate the model results presented in this report.

PEST was run twice, first using the steady-state groundwater flow model and calibration targets (measured quantities), then using the transient model and transient calibration targets. The steady state calibration process produced estimates of parameters value distributions (that is, multipliers applied to initial parameter values) for both horizontal and vertical hydraulic conductivity for each of the HUF units and one parameter value distribution for the conductance of all river boundary conditions. The aquifer properties were initialized for the PEST run at values derived from the preliminary model using manual calibration methods, and were allowed to vary during the PEST run within bands of an order of magnitude either side, that is, $0.1 \times$ to $10 \times$ of the initial parameter value distributions. The steady-state model used as observations (calibration targets) both the measured water-level altitudes from monthly and synoptic monitoring wells (table 4), as well as the estimated baseflows in the four tributary subbasins (Savoca and others, 2009a).

Parameter value distributions from the steady-state PEST calibration run were then used as initial estimates for the transient PEST calibration. The transient calibration allowed these hydraulic conductivity parameters to vary again, within an order of magnitude limit. The transient run also allowed calibration of storage coefficient parameters, starting with the values derived from the manually calibrated preliminary transient model. PEST allowed the storage coefficients to vary across much wider limits: allowing a reduction of $0.001 \times$ to an increase of between 100 and 1,000,000 (the upper limit was adjusted to assure that the storage coefficient would not mistakenly become close to an impossible value of 1.00 - it turned out that these upper limits did not affect the calibration). After the transient model was calibrated using PEST, the resultant parameter value distributions (for hydraulic conductivity and stream conductance) were re-introduced into the steady-state model to generate subsequent steady-state model results.

\section{Calibration Data}

The Skagit River tributary subbasin groundwater-flow model was calibrated using both groundwater-level and stream baseflow measurements. Water-level measurements from Savoca and others (2009a) include: (1) monthly water-level measurements for 70 monitoring wells from October 2006September 2008, and (2) synoptic water-level measurements for 52 wells measured during August-September 2006.

A total of 1,371 groundwater-level measurements were used in the model calibration, including the data that were flagged as pumping $(\mathrm{P})$, recovering $(\mathrm{R})$, flowing $(\mathrm{F})$ and dry (D). Water-level measurements for each monthly well were averaged to get the steady-state calibration target value for that well. Each steady-state calibration groundwater level, as depth below land surface, was converted to a water level altitude, according to the North American Vertical Datum, based on the LiDAR-derived land surface altitude at the location of the well. The average water levels for monthly wells and single water-level measurements for synoptic wells used during model calibration for each HUF unit are reported in Savoca and others (2009a; figs. 14-18). 


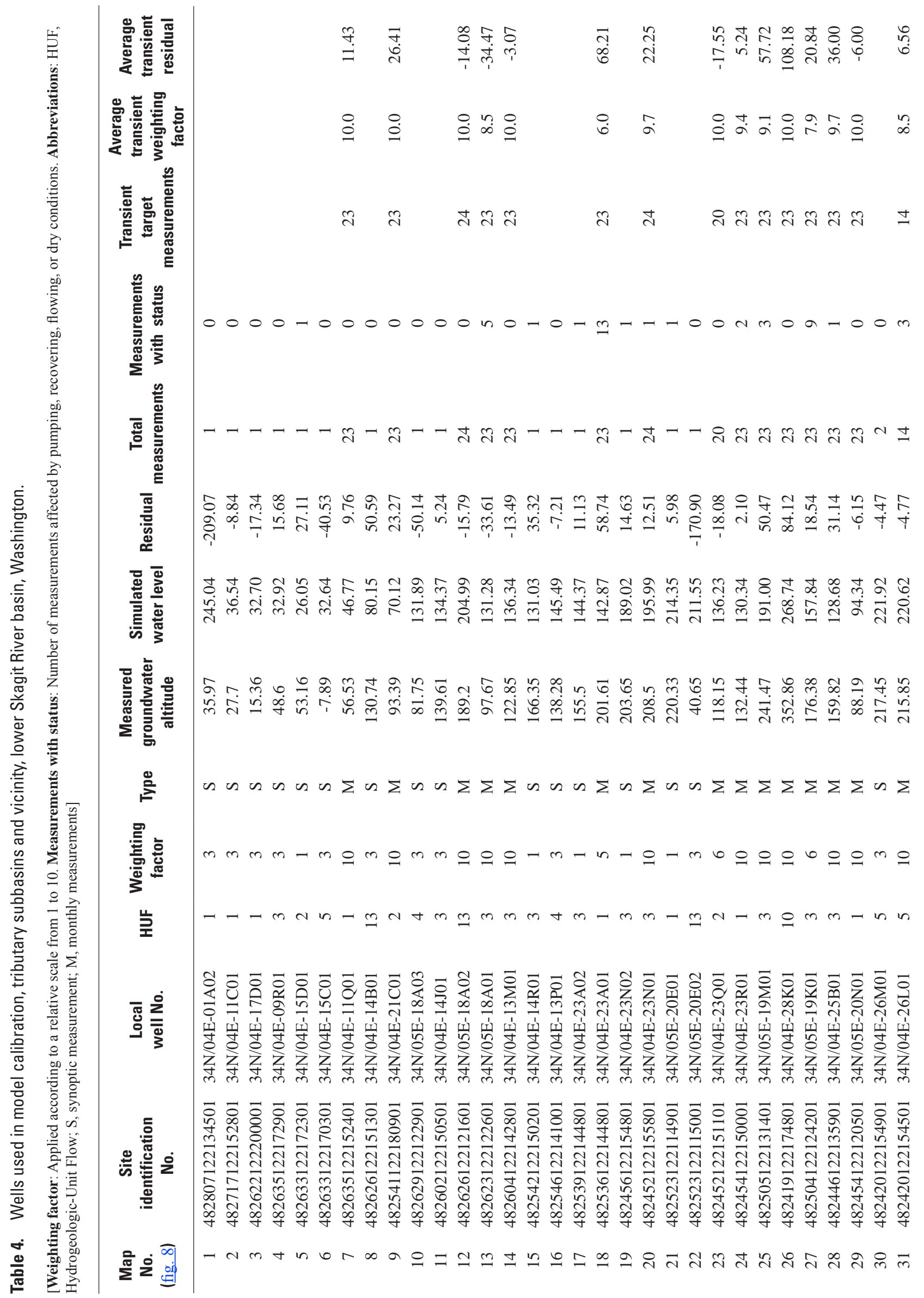




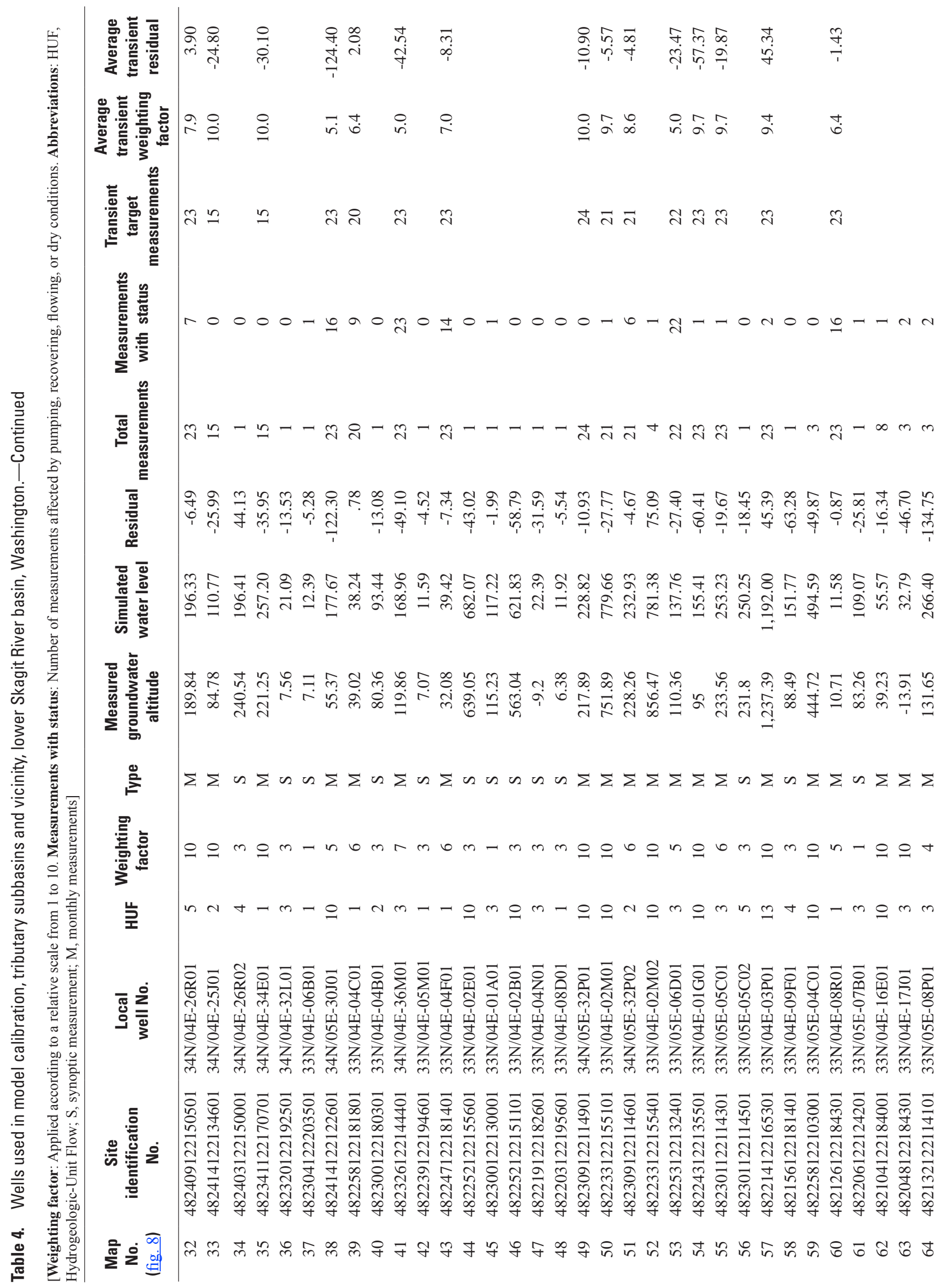




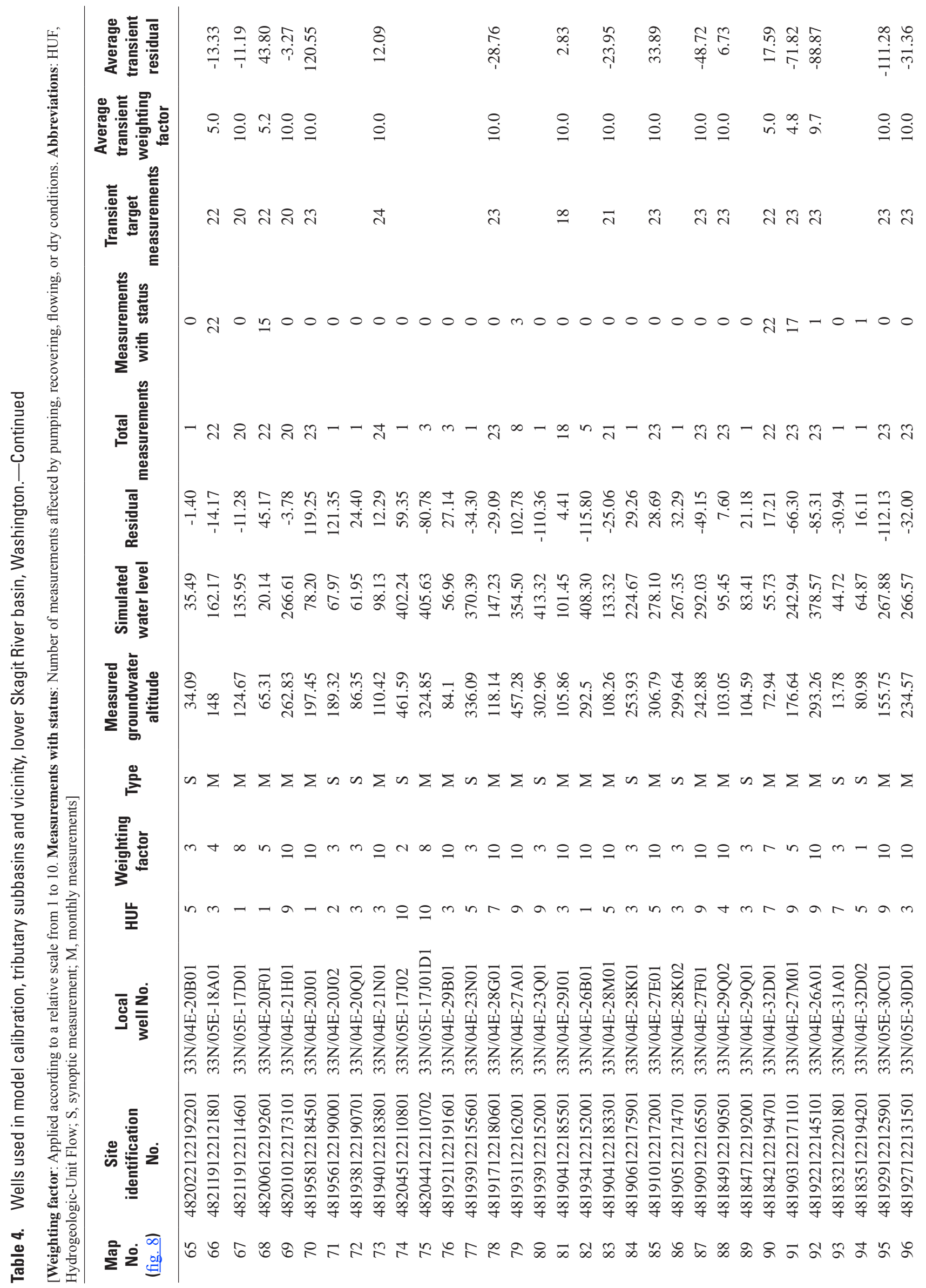




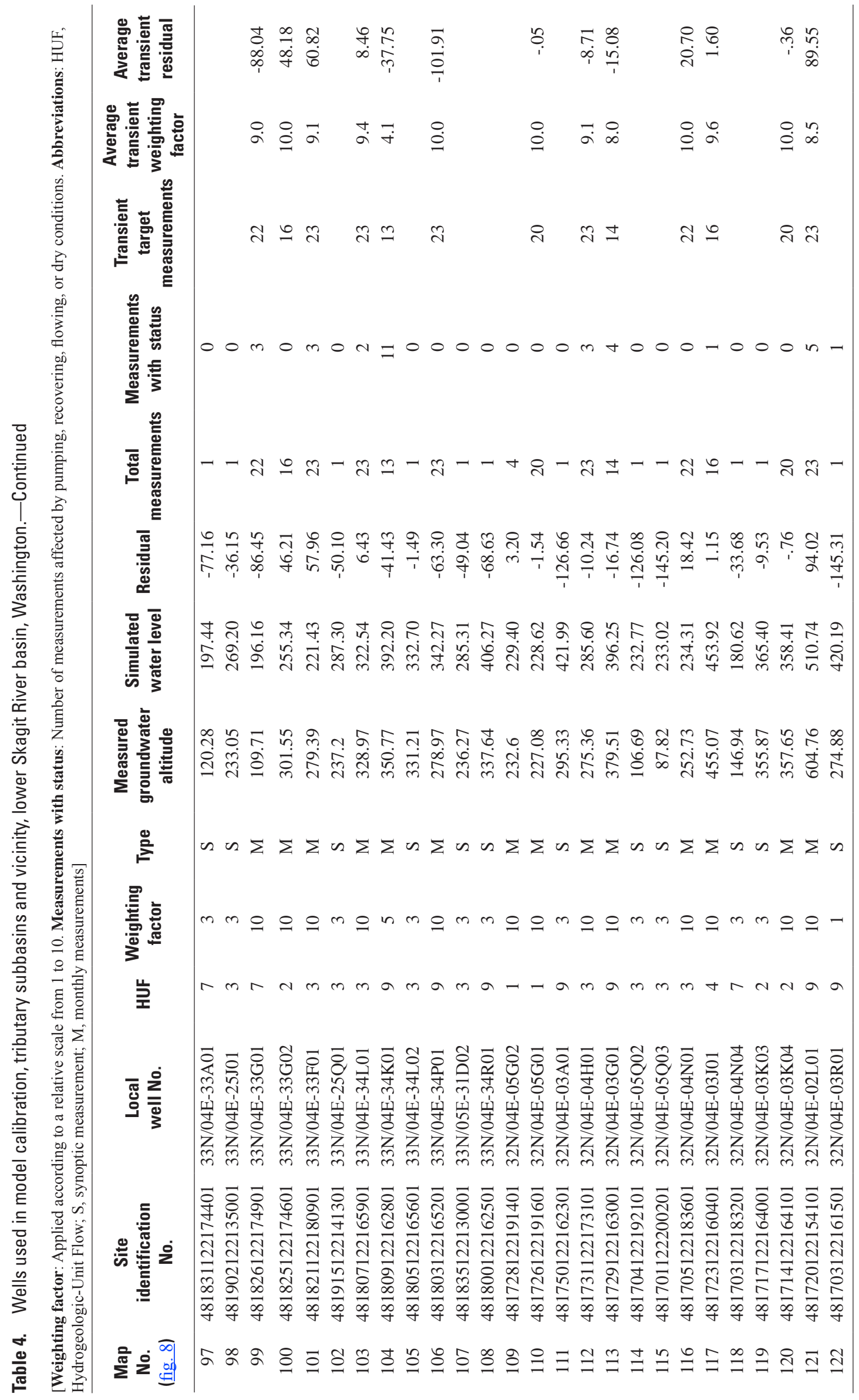


After each steady-state model run the groundwater calibration data were compared to model-derived water levels obtained through the MODFLOW Observation Process module. Each calibration well was located within a model cell at a location given by the measured latitude and longitude of the well. Each well was determined to screen a specific hydrogeologic unit, based on the reported depth of the screen section and the drillers' descriptions in the well log. The calibration point was placed vertically at an altitude point corresponding to the center of the hydrogeologic unit in the model cell, and located in the model layer containing the hydrogeologic unit at that altitude. This process results in an acceptable discrepancy between the model simulated screen altitude (approximated by the center of the hydrogeologic unit) and the altitude based on the reported depth of the well screen section (from the drillers' log), because it was considered more important to correlate the water-level measurements with the appropriate hydrogeologic unit.

Stream baseflow measurements were used in the calibration process to evaluate the surface water and groundwater interface of the calibrated model. The measured stream baseflows were compared graphically with model-predicted river boundary condition flows as totaled over the basin that contributes to the stream baseflow measurement location. Stream baseflow at 28 locations was measured during two synoptic streamflow measurements conducted in August 2007 and June 2008 to identify gaining and losing creek reaches along segments of East Fork Nookachamps, Nookachamps, Carpenter, and Fisher Creeks. Stream baseflow measurement locations and discharge values used during calibration are given in Savoca and others (2009a, pl. 1 and table 4, respectively).

\section{Initial Conditions}

Initial conditions refer to the state (that is, water levels) of the groundwater system at the beginning of the transient model calibration period (September 2006-September 2008). The method for developing initial conditions for the transient model used a 6-year "lead-in" period (September 2000September 2006) to establish water levels in the model for use in the beginning of the calibration period. Temporal discretization of the "lead-in" period consisted of: an initial steady-state condition stress period, followed by two 1-year transient stress periods, eight 3-month transient stress periods, and 24 monthly transient stress periods. Each of the "lead-in" stress periods simulated recharge based on precipitation records for each time period. Well withdrawals (and return flows) were simulated using the same spatial distribution of wells used in the transient calibration period, with adjusted withdrawal rates to reflect population change during the "lead-in" period. Skagit River stage was obtained from USGS records, and temporal fluctuations in other model boundary conditions were patterned after fluctuations delineated for the calibration period.

\section{Weights for Measured Quantities}

In both the steady-state and transient model calibrations, PEST used as observations both groundwater-level and stream baseflow measurements. The steady-state calibration used the average values for these measurements, and the transient calibration used each of the monthly water-level and baseflow measurements.

The process of calibration requires an "objective function," which includes weighting factors to adjust for the accuracy of each of the observations. The weighting factors (table 4) were applied according to a relative scale from 1 to 10 . For the steady-state calibration, the weighting was defaulted to 10 for monthly wells but was reduced for a few of the monthly wells when the averages were less accurate due to measurements that were impacted from pumping (status = "P" for pumping or " $\mathrm{R}$ " for recovering) or by limitations of the well (status = " $F$ ' for flowing or " $D$ " for dry), although these measurements were included in the measured (average) value. The relative weighting also was reduced if LiDAR altitudes were not available at the well location, so that the water-level altitude had to be derived from the less accurate topographic DEM. For these reasons, monthly wells had weighting factors assigned between 4 and 10, which were considered to be approximately inversely proportional to the standard deviations of the waterlevel measurements. Synoptic wells, with only one or two measurements, were assigned a default weighting factor of 3 , which was in some cases reduced to 1 , depending on the status of the measurement. The weighting factors for the steady state calibration are shown in table 4. For the transient calibration, each monthly water-level measurement from a monthly well was included as a separate observation, again with a default weighting factor of 10 , reduced in some cases according to the status of the measurement -5 for " $F$ " measurements, 3 for "P" or " $R$ " measurements, and 2 for " $D$ " measurements - that limited the accuracy of the measurement.

Estimates of stream baseflow in the four tributary basins were included in both steady-state and transient calibrations. These measurements were weighted with a factor of 0.001 to account for their numerically larger values (that is, different measurement units: cubic feet per day rather than feet for the water-level measurements) and the greater uncertainty (standard deviation) associated with baseflow measurements. The different weighting factors used for water-level and baseflow measurements also served to balance the contribution of each type of observation to the overall objective function, so that each would be considered in the calibration process.

Table 4 shows the wells that were used for the calibration and their assigned steady state calibration weighting factors, along with the HUF unit they were associated with, the total number of (transient) observations, and the number of observations that were reduced for the status of the water- level reading. For those wells which were used for the transient calibration, the table shows the number of observations and the average weighting factor for the observations in that well. The locations of the wells (as identified by the well map numbers in table 4) are shown in figure 8. 


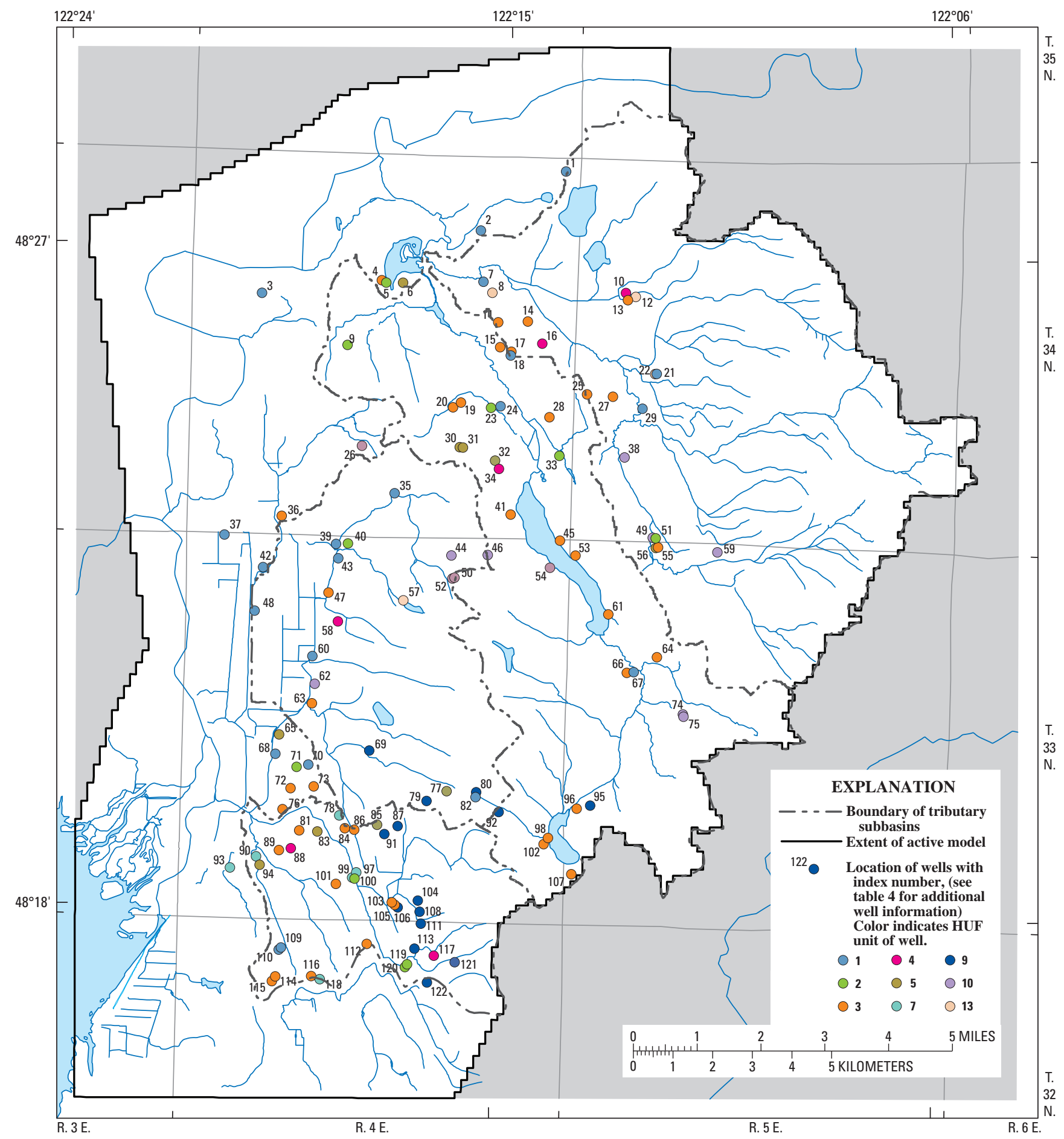

Figure 8. Locations of wells used in model calibration, tributary subbasins and vicinity, lower Skagit River basin, Washington. 
The weighting factors were selected to approximate the relative standard deviation accuracies of the various observation categories although a formal error analysis was not performed. There are a number of other contributions to error in the observations besides the status of the water-level reading. These uncertainties include the estimates of the well land-surface altitude and depth of screen, the depth and HUF unit or model layer that each well is estimated to be screened in, and the errors of the model process in general (spatial and temporal discretization, assumed uniformity of aquifer properties throughout a HUF layer, and inaccuracies of boundary conditions).

\section{Parameter Sensitivity}

Sensitivity is the relative effect that changes in an individual parameter value has on the overall objective function. Each PEST optimization iteration provided an estimate of the sensitivities of the parameters at that step in the optimization process. The sensitivities of the parameters, to the overall objective function including both head (water level) and stream-baseflow target values, are shown in figure 9. The wide range of sensitivities dictated that a logarithmic scale be used to represent sensitivity values. Because the objective function is nominally scaled by the weighting factors (as inverse standard deviations) and the parameter changes are multiplicative, the sensitivity can be considered non-dimensional, although the objective function (for heads) is conventionally reported to be in units of feet squared.

It can be seen in figure 9 that the model is most sensitive to values of $K_{x}$, particularly in HUF units $1,2,3,7,9,10$. HUF units 9 and 10 are sedimentary aquifer units, although the other sensitive HUF units are unconsolidated glacial aquifers (except the unconsolidated glacial till of HUF unit 2). Sensitivities of the $K_{z}$ parameters generally are much lower than $K_{x}$, particularly for most of the sedimentary and bedrock units (HUF units 9, 10, 11, 13, and 14).

The model is relatively much less sensitive to the storage coefficients used in the HUF units, most of which had sensitivities orders of magnitude below unity. The model was calibrated in transient mode using water-level altitudes (for example, feet above sea level) target values. A groundwater flow model in transient mode also can be calibrated with PEST using "relative" water levels targets such as seasonal or monthly fluctuations above and below the average water level in that well (for example, feet above the average). The water-level altitude method that was used for this model emphasized the actual water levels and thus gave less attention to the seasonal or monthly fluctuations in the wells.

\section{Final Parameter Values}

Final values of hydraulic conductivities, vertical anisotropy, and specific storage coefficients are shown in $\underline{\text { table 5}}$, as determined through the transient PEST calibration process for each of the HUF units, and the relative effect of the river conductance. PEST calibration was terminated after six "Optimization Iterations" rather than allowing the program to terminate on its own criteria. The value of the objective function (phi) had reduced to 95 percent of the original value and was changing only by 0.07 percent in the final optimization iteration.

Six of the model parameters were reported to have reached the limits that had been placed on changes in parameter value in the transient PEST procedure: $K_{x}$ in HUF units 6 and 12 and $K_{z}$ in HUF units 9 and 10 were projected to increase higher than the factor of 10 that was allowed in the calibration process, and the $K_{x}$ and $K_{z}$ for HUF unit 14 was projected to decrease lower than the 0.1 lower limit. Despite these limits, none of the limited values showed significant sensitivity (see previous section on Parameter Sensitivity). None of the storage coefficient parameters had reached their limit. Other than the limited values mentioned above, the parameters had changed over the course of the transient PEST calibration by factors of:

\begin{tabular}{|l|l|}
\hline$K_{x}$ & 25 to 114 percent \\
\hline$K_{z}$ & 18 to 308 percent \\
\hline Storage coefficients & 8 to 245 percent \\
\hline
\end{tabular}

from the PEST calibrated steady-state parameters. These relative changes are within the range of possible changes that can be observed in the regional values of hydraulic aquifer properties.

Calibrated horizontal hydraulic conductivity values in aquifer units (table 5) ranged from $0.002 \mathrm{ft} / \mathrm{d}$ in the deeper part of the sedimentary aquifer (HUF11) to $166 \mathrm{ft} / \mathrm{d}$ in the older outwash and alluvial aquifer (HUF7). Calibrated horizontal hydraulic conductivity values in confining and bedrock units ranged from $3.0 \times 10^{-5} \mathrm{ft} / \mathrm{d}$ in the deeper part of the igneous and metamorphic bedrock unit (HUF14) to $1.0 \mathrm{ft} / \mathrm{d}$ in the older till confining unit (HUF6). Undifferentiated glacial and inter-glacial deposits (HUF8) were simulated using a calibrated horizontal hydraulic conductivity value of $0.543 \mathrm{ft} / \mathrm{d}$.

Calibrated specific storage values for aquifer units (table 5) ranged from $1.92 \times 10^{-8} \mathrm{ft}^{-1}$ in the deeper part (greater than $200 \mathrm{ft}$ ) of the sedimentary aquifer (HUF unit 11) to $4.91 \times 10^{-3} \mathrm{ft}^{-1}$ in the inter-glacial alluvial aquifer (HUF5). Calibrated specific storage values for confining units ranged from $8.22 \times 10^{-8} \mathrm{ft}^{-1}$ in the deeper part of the igneous and metamorphic bedrock unit (HUF14) to $0.002 \mathrm{ft}^{-1}$ in the till confining unit (HUF2). Undifferentiated glacial and inter-glacial deposits (HUF8) were simulated using a calibrated specific storage value of $8.99 \times 10^{-5} \mathrm{ft}^{-1}$. 


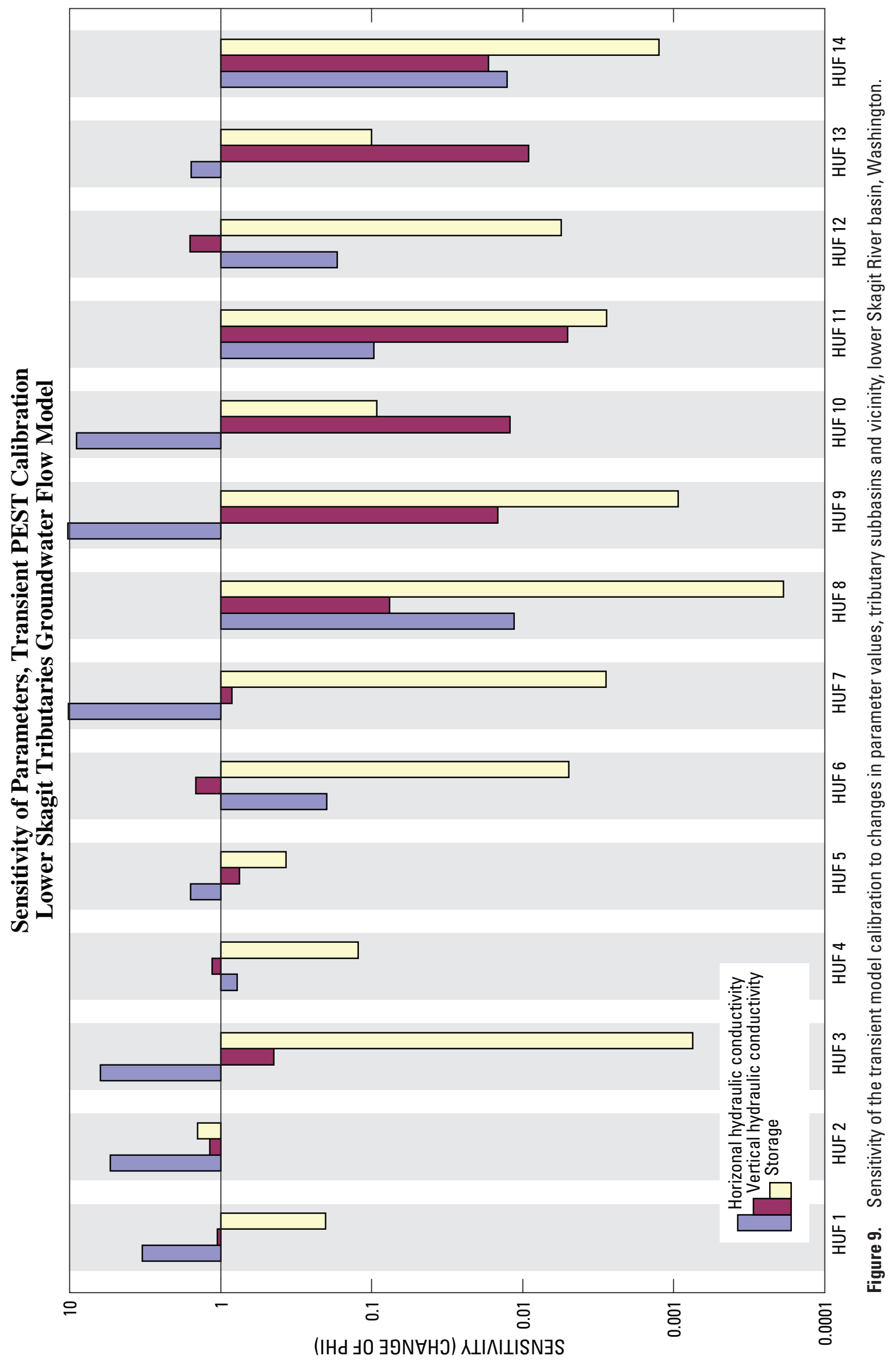


Table 5. Final hydraulic property values of HUF units used in the steady-state and transient model, tributary subbasins and vicinity, lower Skagit River basin, Washington.

[Verticle anisotropy: Anisotropy is calculated from final estimated $K_{x}$ and $K_{z}$ values, not estimated as a separate parameter Abbreviations: HUF, Hydrologic Unit Flow; $\mathrm{ft} / \mathrm{d}$, foot per day; $\mathrm{ft}^{-1}$, per foot thickness of unit]

\begin{tabular}{|c|c|c|c|c|c|c|c|}
\hline HUF unit & $\begin{array}{c}K_{x} \\
(\mathrm{ft} / \mathrm{d})\end{array}$ & $\begin{array}{l}\text { Change from } \\
\text { initial Kx }\end{array}$ & $\begin{array}{c}K_{z} \\
(\mathrm{ft} / \mathrm{d})\end{array}$ & $\begin{array}{c}\text { Vertical } \\
\text { anisotropy }\end{array}$ & $\begin{array}{c}\text { Change } \\
\text { from initial } \\
\text { anistrophy }\end{array}$ & $\begin{array}{c}\text { Specific } \\
\text { storage } \\
\text { coefficient } \\
\left(\mathrm{ft}^{-1}\right)\end{array}$ & $\begin{array}{l}\text { Change from } \\
\text { initial specific } \\
\text { storage }\end{array}$ \\
\hline 1 & 5.02 & X 0.11 & 8.63 & 0.58 & X 0.06 & 2.18E-03 & X 0.02 \\
\hline 2 & .646 & X 0.43 & .166 & 3.89 & X 0.04 & 2.05E-03 & X 0.01 \\
\hline 3 & 2.77 & X 0.06 & .314 & 8.81 & X 0.88 & $1.08 \mathrm{E}-06$ & X 7.2E-06 \\
\hline 4 & .370 & X 0.37 & .126 & 2.94 & X 0.03 & $9.30 \mathrm{E}-04$ & X 0.93 \\
\hline 5 & 1.81 & X 0.09 & .0803 & 22.5 & X 2.3 & 4.91E-03 & X 4.9 \\
\hline 6 & ${ }^{1} 1.00$ & Same & .000781 & 1,280 & X 13 & $2.40 \mathrm{E}-05$ & X 0.02 \\
\hline 7 & 166 & X 4.16 & .296 & 562 & X 56 & $2.22 \mathrm{E}-05$ & X 0.02 \\
\hline 8 & .543 & X 0.012 & .0328 & 16.56 & X 1.7 & 8.99E-05 & X 0.002 \\
\hline 9 & 5.35 & X 13.4 & ${ }^{1} 100$ & .053 & X 0.54 & 4.78E-08 & X 4.8E-05 \\
\hline 10 & .324 & X 0.81 & ${ }^{1} 20$ & .016 & X 0.16 & 3.63E-05 & X 0.04 \\
\hline 11 & .00199 & X 0.04 & .381 & .005 & X 0.005 & $1.92 \mathrm{E}-08$ & X 1.9E-04 \\
\hline 12 & ${ }^{1} 1.00$ & X 20 & .000238 & 4,209 & X 4,200 & 2.48E-06 & X 0.025 \\
\hline 13 & .0248 & X 0.36 & .994 & .025 & X 0.25 & $1.31 \mathrm{E}-06$ & X 0.001 \\
\hline 14 & ${ }^{2} .00003$ & X 0.004 & ${ }^{2} .00003$ & 1.00 & Same & 8.22E-08 & X 0.008 \\
\hline River conductance & & & ${ }^{3} 2.77 \times$ initial & & & & \\
\hline
\end{tabular}

\footnotetext{
${ }^{1}$ Values of Kx for HUF units 6 and 12, and Kz for units 9 and 10 were limited from increasing further in the parameter estimation process due to upper bound constraints.

${ }^{2}$ Values of $\mathrm{Kx}$ and $\mathrm{Kz}$ for HUF unit 14 were limited from decreasing further in the parameter estimation process due to lower bound constraints.

${ }^{3}$ River conductances were modified multiplicatively by this factor in all river boundary conditions, based on values developed in preliminary model, during the parameter estimation process.
}

The final hydraulic property values, derived from the PEST calibration process, are notably different in a few cases from the initial values that were expected for these properties, as previously estimated by Savoca and others (2009a, table 3). Most notably, the anisotropies of the calibrated hydraulic conductivities were initially estimated to be $K_{\chi} / K_{z}=10$ for aquifers (HUF units 1, 3, 5, 7), 100 for confining units (HUF units 2, 4, 6), 0.1 for shallow sedimentary aquifer and bedrock units (HUF units 9, 10,13), and 1 for deep sedimentary aquifer and bedrock units $(11,12,14)$. In the calibrated model, units in the upper part of the groundwater system (HUF units $1,2,3,4$ ) tended to have lower values of anisotropy than initially anticipated especially in confining units. The unconsolidated units in the lower part of the system (HUF units $5,6,7)$ tended to have higher values of anisotropy than initially anticipated, particularly HUF unit 7 . The anisotropy is calculated from the calibrated conductivities rather than being estimated separately, but this should not change the results significantly.
Calibrated horizontal hydraulic conductivity values generally are similar to initial estimates, with higher conductivities for aquifers and lower values for confining units. Calibrated horizontal hydraulic conductivity values for sedimentary aquifer and bedrock units were both higher and lower than initial estimates. However, little information was available about the hydraulic properties of these units prior to the study.

\section{Assessment of Steady-State Calibration}

The results of the steady-state calibration were assessed by comparing measured and simulated quantities (such as groundwater levels and stream baseflows) and by examining the weighted mean of residuals for average monthly and synoptic groundwater levels. The statistic used in the assessment is the weighted sum of squared residuals (objective function). The weighted mean of residuals represents the 
average weighted difference between all measured and simulated values (residuals), and the sign of the weighted mean of residuals indicates whether the model is over- or underpredicting values (negative and positive weighted mean of residuals, respectively). The objective function represents the weighted total of all squared residuals, and the magnitude of the objective function is a measure of the cumulative difference between all measured and simulated values. The goal of the model calibration process is to minimize the objective function. The objective function weighted mean of residuals were calculated according to the hydrogeologic unit the wells represent and the subbasin where the wells are located. These results are presented in tables 6 and 7 .
Table 6 shows the calibration statistics for the steady-state calibration associated with groundwater-level measurements by HUF unit. By comparing the amount of error (percentage of the objective function) with the weight of the groundwater-level measurements (by HUF unit), it is possible to determine how well the model simulates measured values (fit) for each HUF unit. The best fit for simulated and measured groundwater-level values occurred in HUF units 5, 4, and 2; the worst fit occurred in HUF units 9, 1, and 10. HUF units 13,4 , and 1 had the lowest weighted mean residual.

Table 6. Calibration statistics for steady-state target water levels by HUF unit, tributary subbasins, lower Skagit River basin, Washington.

[O bjective function: In calibration process included streamflow targets, but this table includes only water level (head) targets. A bbreviations: $\mathrm{ft}^{2}$, cubic feet per second; $\mathrm{ft}$, feet]

\begin{tabular}{|c|c|c|c|c|c|c|}
\hline \multirow{2}{*}{ HUF unit } & \multirow{2}{*}{$\begin{array}{l}\text { Count of } \\
\text { wells }\end{array}$} & \multicolumn{2}{|c|}{ Weight } & \multicolumn{2}{|c|}{ Objective function } & \multirow{2}{*}{$\begin{array}{l}\text { Weighted } \\
\text { Mean of } \\
\text { residuals } \\
\text { (ft) }\end{array}$} \\
\hline & & Total & Percent & $\begin{array}{l}\text { Total } \\
\left(\mathrm{ft}^{2}\right)\end{array}$ & Percent & \\
\hline 1 & 21 & 132 & 18 & 452,029 & 21 & -4.6 \\
\hline 2 & 10 & 62 & 8 & 81,324 & 4 & +9.9 \\
\hline 3 & 39 & 219 & 29 & 372,911 & 17 & -5.4 \\
\hline 4 & 6 & 32 & 4 & 26,144 & 1 & -4.4 \\
\hline 5 & 10 & 56 & 7 & 24,965 & 1 & -6.4 \\
\hline 7 & 6 & 36 & 5 & 109,415 & 5 & -40.6 \\
\hline 9 & 14 & 100 & 13 & 610,173 & 28 & -29.4 \\
\hline 10 & 12 & 91 & 12 & 350,032 & 16 & -16.5 \\
\hline 13 & 4 & 26 & 3 & 118,393 & 6 & -2.5 \\
\hline All wells & 122 & 754 & & $2,145,386$ & & -10.1 \\
\hline
\end{tabular}

Table 7. Calibration statistics for steady-state target water levels by tributary basin, lower Skagit River basin, Washington.

[O bjective function: In calibration process included streamflow targets, but this table includes only water level (head) targets. A bbreviations: $\mathrm{ft}^{2}$, cubic feet per second; ft, feet]

\begin{tabular}{|c|c|c|c|c|c|c|}
\hline \multirow[b]{2}{*}{ Basin } & \multirow{2}{*}{$\begin{array}{c}\text { Count of } \\
\text { wells }\end{array}$} & \multicolumn{2}{|c|}{ Weight } & \multicolumn{2}{|c|}{ Objective function } & \multirow{2}{*}{$\begin{array}{l}\text { Weighted } \\
\text { mean of } \\
\text { residuals } \\
\text { (ft) }\end{array}$} \\
\hline & & Total & Percent & $\begin{array}{l}\text { Total } \\
\left(\mathrm{ft}^{2}\right)\end{array}$ & Percent & \\
\hline East Fork Nookachamps & 21 & 128 & 17 & 269,289 & 13 & -12.5 \\
\hline Main Stem Nookachamps & 29 & 176 & 23 & 462,719 & 22 & -27.4 \\
\hline Carpenter Creek & 26 & 172 & 23 & 630,799 & 29 & +6.2 \\
\hline Fisher Creek & 33 & 238 & 32 & 545,121 & 25 & -8.2 \\
\hline Skagit River Valley & 13 & 40 & 5 & 237,457 & 11 & -7.8 \\
\hline All wells & 122 & 754 & & $2,145,386$ & & -10.1 \\
\hline
\end{tabular}


Table 7 shows the calibration statistics for the steady-state calibration associated with groundwater-level measurements by tributary subbasins and the Skagit River Valley. The best fit for simulated and measured groundwater-level values occurred in East Fork Nookachamps Creek subbasin and the Skagit River Valley; the worst fit occurred in Carpenter and Fisher Creek subbasins. Carpenter Creek subbasin and the Skagit River Valley had the lowest weighted mean residual.

For the final calibrated model, the objective function (for heads only) was calculated to be $2,145,386 \mathrm{ft}^{2}$. Given the total of the weighting factors as 754 , this gives an average weighted squared residual of $2,845 \mathrm{ft}^{2}$, or a weighted root mean square error of $53.3 \mathrm{ft}$. The weighted mean residual is $-10.1 \mathrm{ft}$, and the overall weighted standard deviation of the residuals is $52.4 \mathrm{ft}$

A plot of measured versus simulated groundwater-level altitudes by HUF unit (fig. 10) provides a useful graphical assessment of model calibration. Measured versus simulated values should plot close to a line with a slope equal to 1.0 and an intercept of zero. This diagonal line represents perfect agreement between measured and simulated values, and the magnitude of the residual (difference between measured and simulated values) is reflected in the distance of the value above or below the line. Positive residuals (measured value is greater than simulated) and negative residuals (measured value is less than simulated) plot below and above the line, respectively. Measured versus simulated values shown in figure 10 generally fall along a straight line with a slope equal to 1.0 and an intercept of zero. The magnitude and sign of residuals for selected HUF units is discussed later in this section of the report.

The results of the steady-state model also were evaluated by displaying the simulated water levels (heads) for the hydrogeologic units in each cell, as calculated and saved (in binary form) by the HUF package of MODFLOW 2000 (Anderman and Hill, 2000). Figures $11 A-F$ show maps of model-simulated water levels for HUF aquifer and bedrock units. The residuals (measured target value minus model-simulated value in that well) for each of the monthly and synoptic wells screened in that hydrogeologic unit are posted at the locations of the wells.

There is a minor inconsistency in the data presented in the figures. Because of limitations associated with the software used for model development and analysis, the residuals computed for the target wells (and used to judge the fit of the calibration) are derived from the model-simulated water levels in the model layers, rather than from the HUF water levels that are shown by graded colors on the figures. The target wells were located in the model to reflect water levels in specific HUF units but had to be input to the model in specific model layers. The HUF Package allows the model to compute average hydraulic properties for numerical cells with more than one hydrogeologic unit. However, the presentation of model results using the HUF Package is limited because simulated water levels are computed for model layers and cannot be strictly assigned to individual HUF units within the layer. The simulated water level in a HUF unit could be either: (1) an average of water levels from more than one model layer (HUF unit present in multiple adjacent model layers), or (2) could be an average of water levels from more than one Huf unit (multiple HUF units present in a single model layer). This discrepancy between the two data sources produces an extra source of model error that is difficult to estimate. This source of error probably is relatively minor, given the number of model layers (15) that are included in the model.

Simulated steady-state groundwater-level altitudes and flow directions (figs. 11A-F) agree generally with groundwater conditions observed by Savoca and others (2009a, figs. 14-18). Some model cells were reported as "missing" a value for the HUF head, even though the HUF unit was defined at the location. The marker for missing data was an indication that the HUF unit was "dry" at the location. Simulated "dry" cells are present only in HUF units 1 through 4, and are most common in high relief areas of the model where these HUF units are thinnest. Because confined conditions are used to simulate all model layers, the occurrence of "dry" cells does not disturb shallow system boundary conditions (for example, groundwater discharge to streams), or produce model instability associated with the MODFLOW rewetting process. The occurrence of simulated "dry" cells is supported by stream gage and baseflow measurements that indicate dry or losing river reaches conditions (Savoca and others, 2009a) that are likely due to seasonal dewatering of the shallow groundwater system.

Simulated groundwater-level altitudes in the alluvial and recessional outwash aquifer (Qago, HUF unit 1, fig. 11A) indicate flow generally moving in a northwesterly direction in the East Fork Nookachamps subbasin toward the Skagit River valley, and flow towards the west and south along the Skagit River valley. Simulated "dry" cells are present throughout the southern part of the model where large areas of low permeability glacial till (Qgt) separate thin and discontinuous bodies of Qago (Savoca and others, 2009a, figs. 2 and 3). Maximum positive (measured value is greater than simulated) and negative (measured value is less than simulated) groundwater-level altitude residuals in the Qago aquifer are 119 and $-209 \mathrm{ft}$, respectively.

Simulated groundwater-level altitudes in the advance outwash aquifer (Qga, HUF unit 3, fig. 11B) indicate flow generally moving in a northerly direction in the Nookachamps subbasin toward the Skagit River valley, and flow to the west in the southern part of the model from upland areas toward the Skagit River valley. Simulated "dry" cells are locally present where thin deposits of Qga overlie sedimentary and bedrock units (Savoca and others, 2009a, fig. 4). Maximum positive and negative groundwater-level altitude residuals in the Qga aquifer are 58 and $-145 \mathrm{ft}$, respectively. 


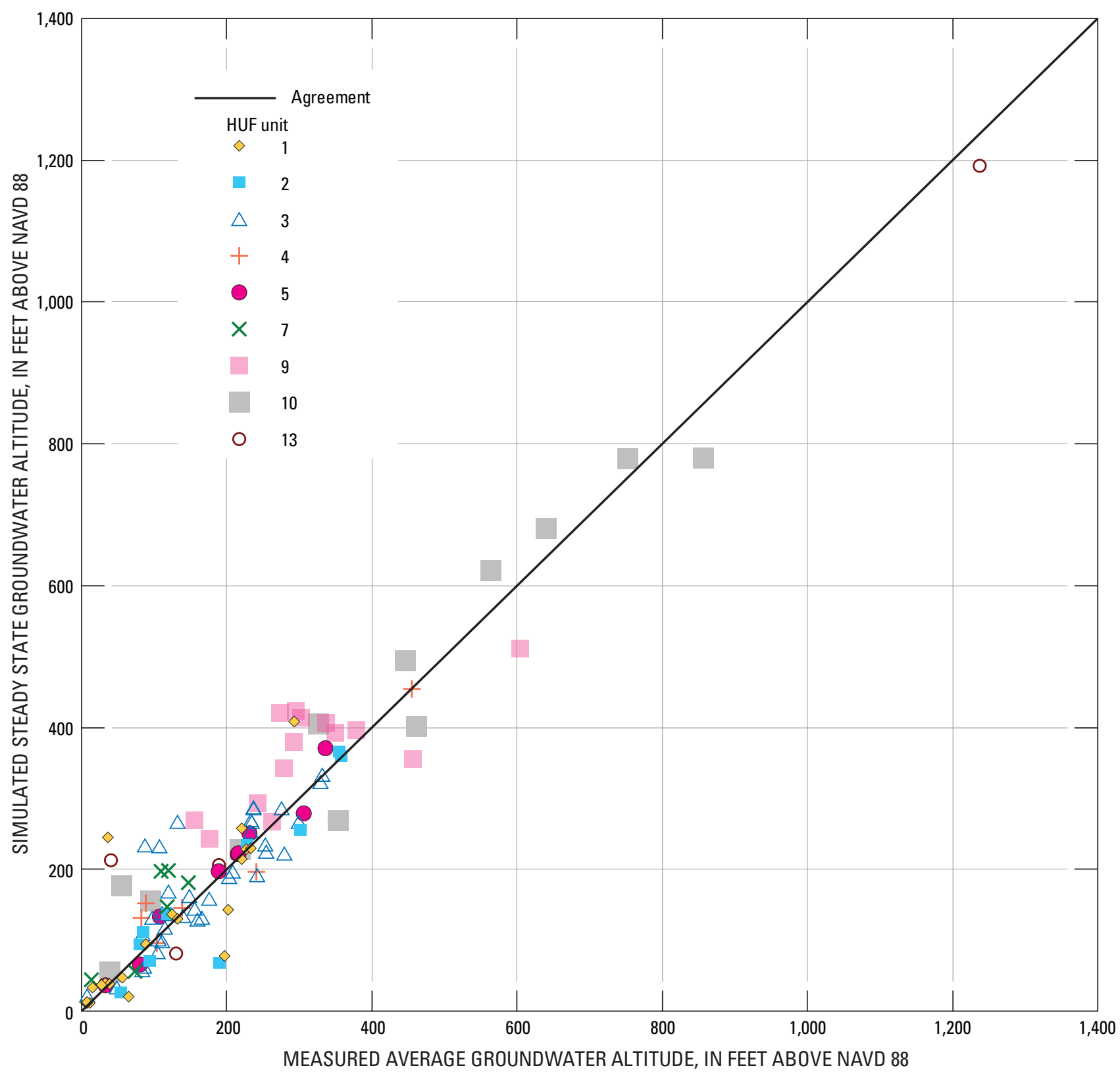

Figure 10. Simulated and measured water-level altitudes by HUF unit for the calibrated steady-state model, tributary subbasins and vicinity, lower Skagit River basin, Washington. 


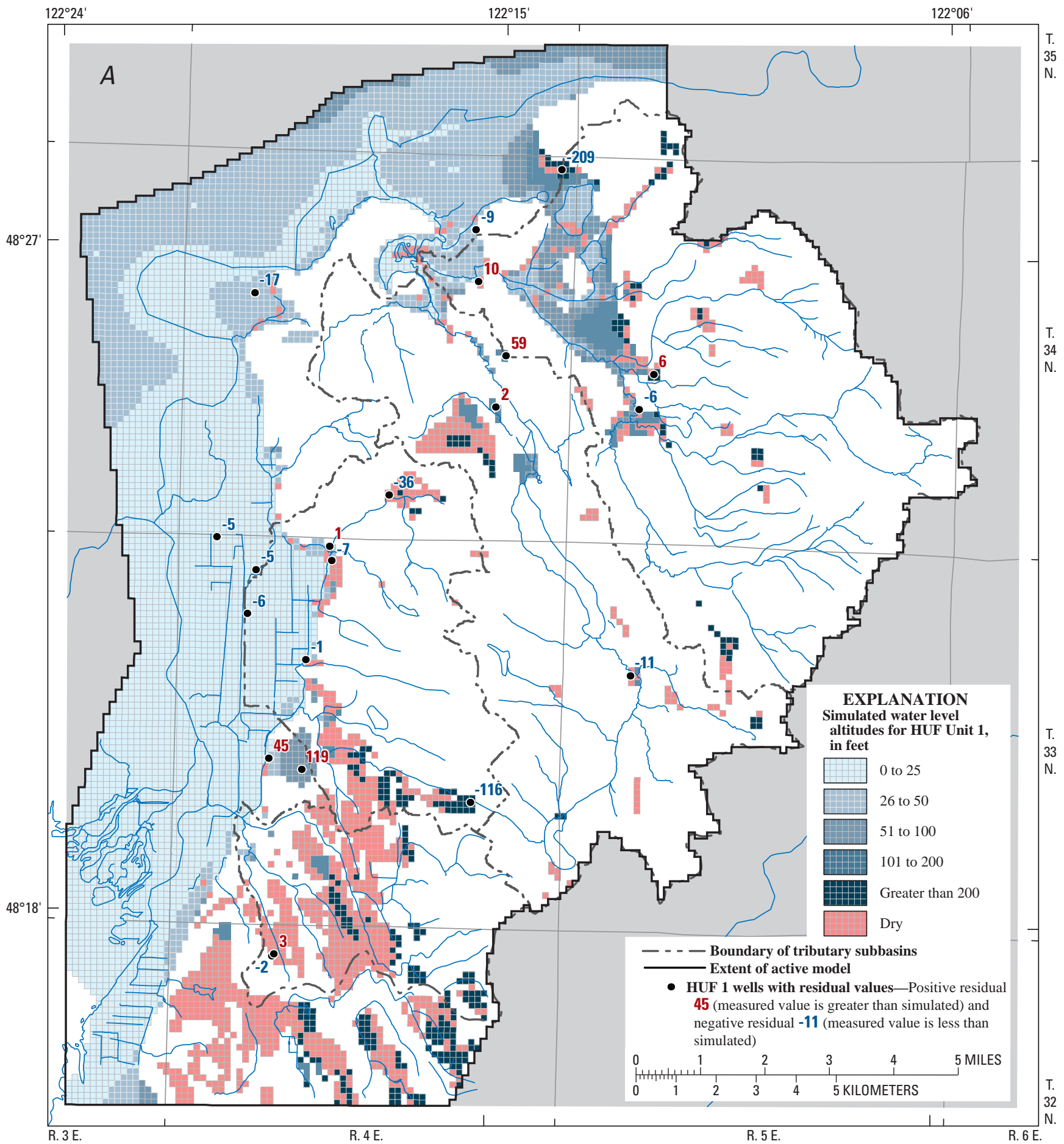

Figure 11. Simulated water-level altitudes and residuals for the calibrated steady-state model, tributary subbasins and vicinity, lower Skagit River basin, Washington. 


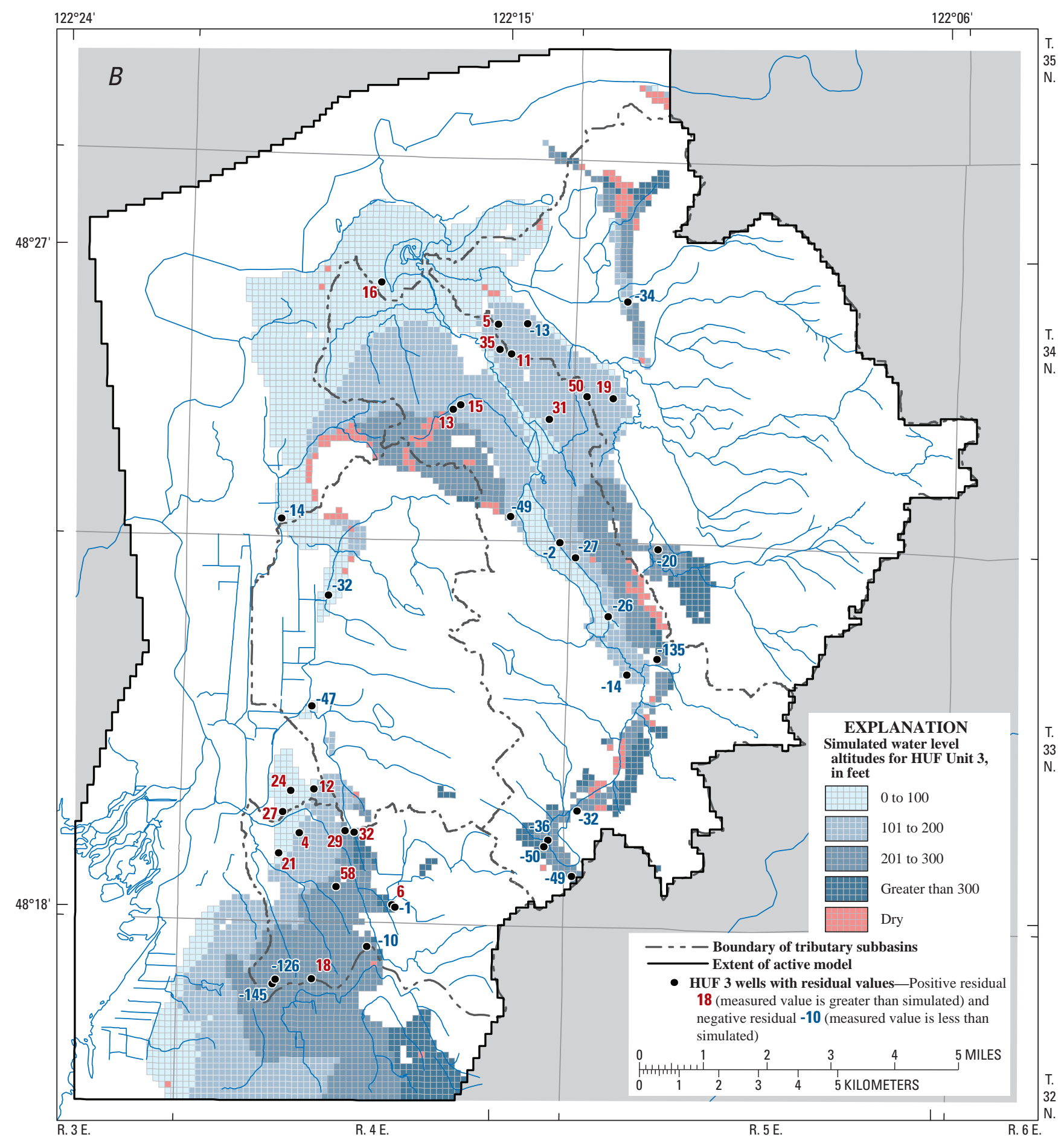

Figure 11.-Continued 


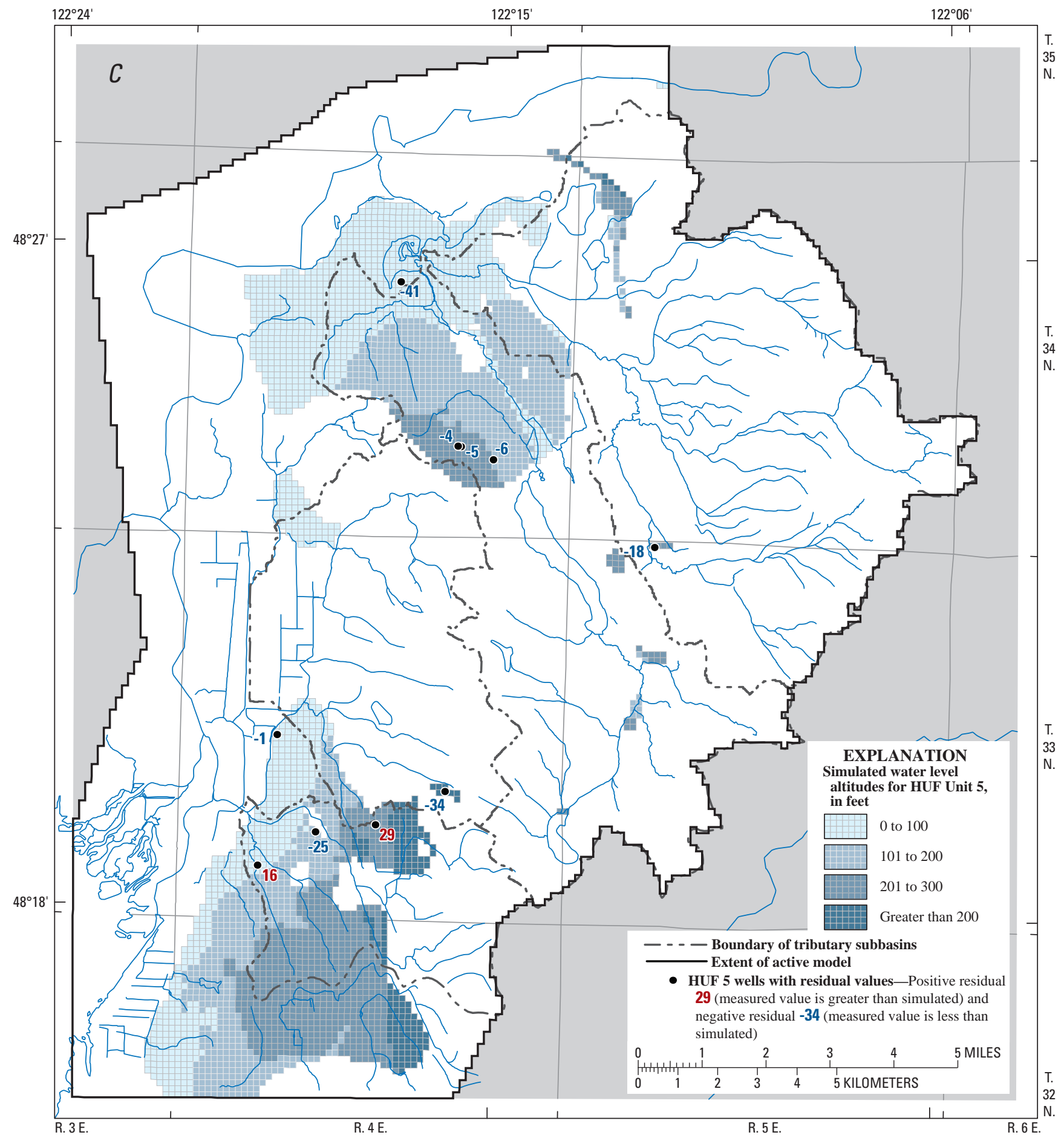

Figure 11.-Continued 


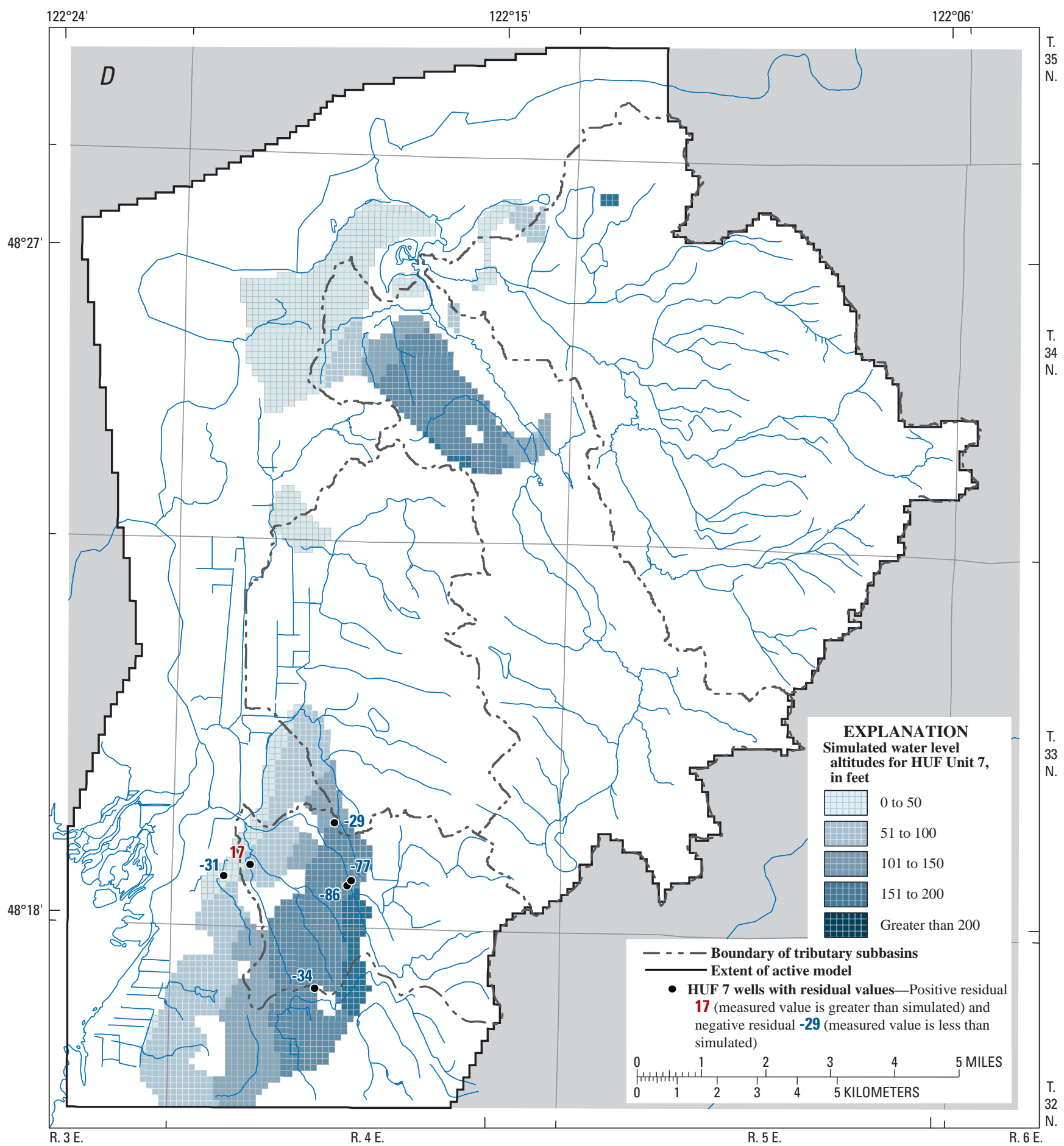

Figure 11.-Continued 


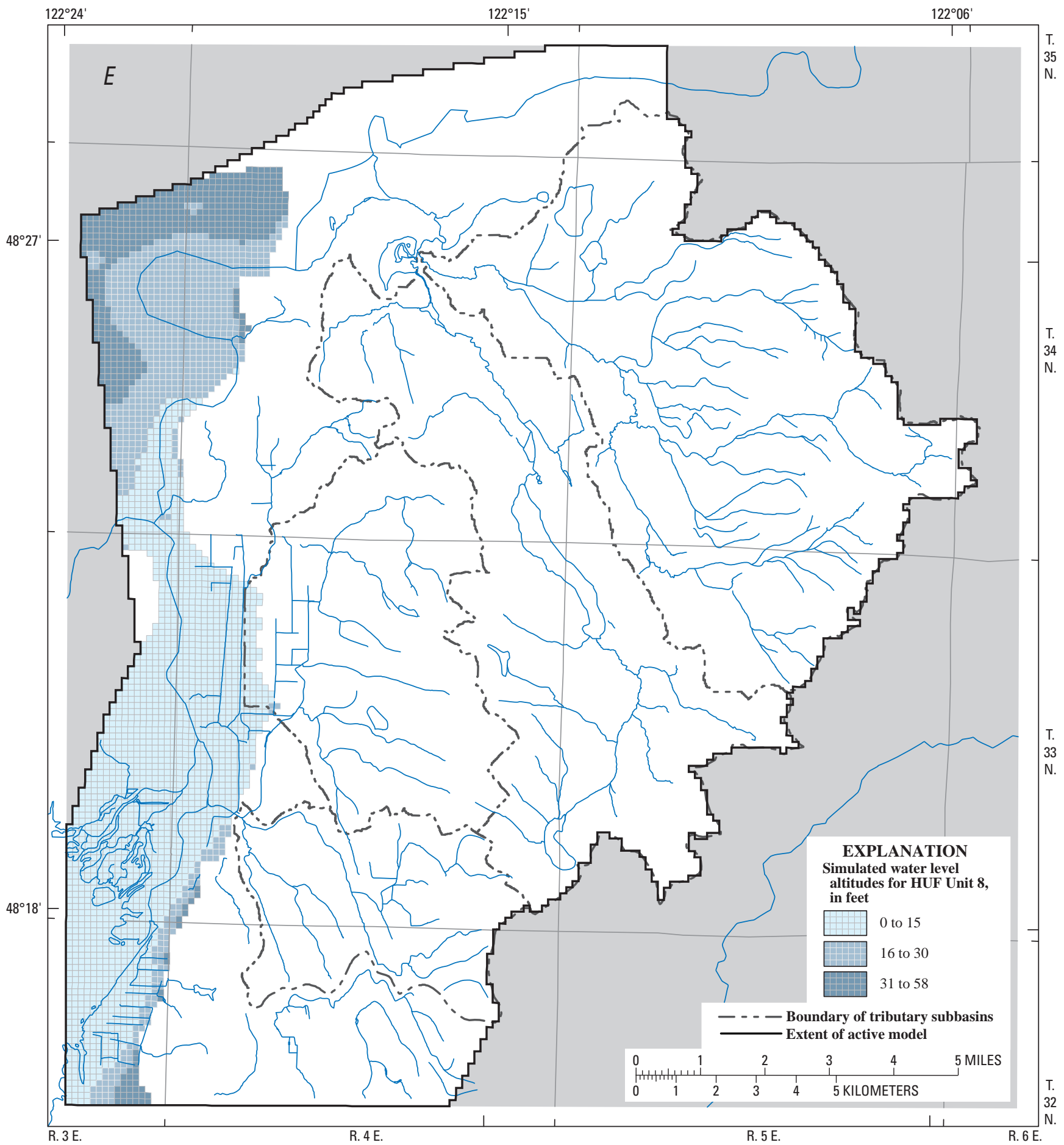

Figure 11.-Continued 


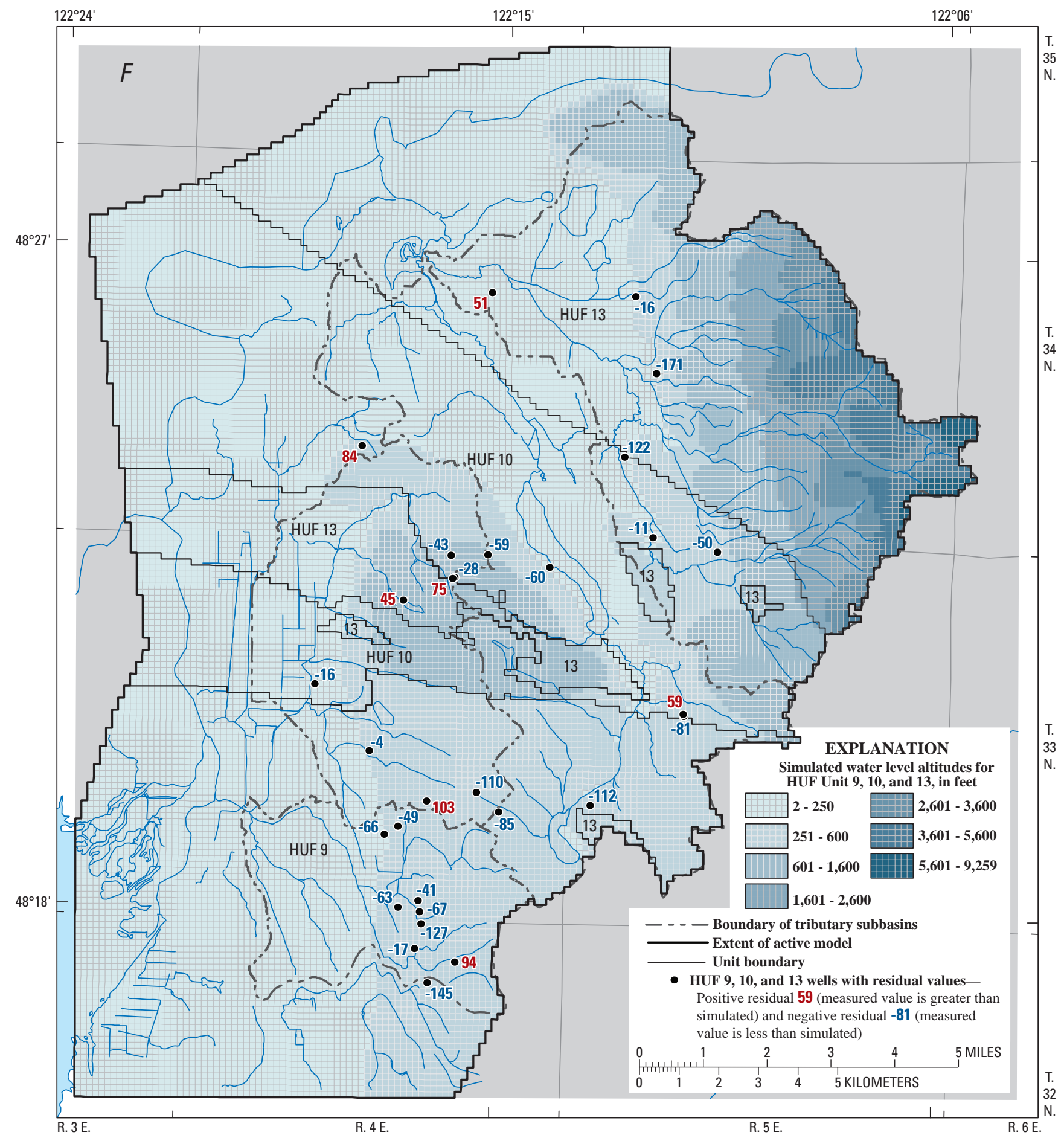

Figure 11.-Continued 
Simulated groundwater-level altitudes in the inter-glacial alluvial aquifer (Qco, HUF unit 5, fig. 11C) indicate flow generally moving in a northerly direction in the Nookachamps subbasin toward the Skagit River valley, and flow to the west in the southern part of the model from upland areas toward the Skagit River valley. Maximum positive and negative groundwater-level altitude residuals in the Qco aquifer are 29 and $-41 \mathrm{ft}$, respectively.

Simulated groundwater-level altitudes in the older outwash and alluvial aquifer (Qooa, HUF unit 7, fig. 11D) indicate flow generally moving in a northwesterly direction along the western part of Nookachamps subbasin toward the Skagit River valley, and flow to the west in the southern part of the model from upland areas toward the Skagit River valley. Maximum positive and negative groundwater-level altitude residuals in the Qooa aquifer are 17 and $-86 \mathrm{ft}$, respectively.

Simulated groundwater-level altitudes in undifferentiated glacial and inter-glacial deposits (HUF unit 8, fig. 11E) indicate flow generally moving in a southerly direction along the Skagit River valley. Deep wells (greater than $300 \mathrm{ft}$ ) were not available in this area; therefore, there are no water level measurements for the computation of residuals.

Simulated groundwater-level altitudes in sedimentary aquifer (OEc, HUF units 9 and 10, fig.11F) and bedrock units (EJTP, HUF unit 13, fig. 11F) reflect both local and regional flow patterns. Recharge to sedimentary and bedrock units preferentially occurs in mountainous areas where these units are exposed at land surface. Water-level altitudes in these areas reflect local topographic relief and suggest radial flow from bedrock highs down beneath the surrounding unconsolidated sediments. Westward groundwater flow occurs along the mountain front in the eastern part of the study area, and is coincident with a regional westward decrease in land surface altitude from the mountains to the Puget Sound. Maximum positive and negative groundwater-level altitude residuals are 103 and $-171 \mathrm{ft}$, respectively.

The calibrated steady-state model also was evaluated for how well it simulated flow out of the model through boundary conditions. A water budget for the steady-state model, both overall and for each of the tributary subbasins, is presented in section, "Model-Derived Groundwater Budget," as calculated by the MODFLOW utility Zonebudget (Harbaugh, 2000).

Groundwater recharge and well withdrawals were determined outside the model and were assigned fixed values as model input; groundwater discharge to rivers and lakes, and flow out of the model to the Skagit River Delta area were simulated in the model according to head dependent boundary conditions.

Groundwater-flow out of the model to the Skagit River Delta was simulated using the General Head Boundary condition along the western extent of model layers 1 and 2 (fig. 2). Savoca and others (2009b) estimated an average annual groundwater flow gradient of $2.67 \mathrm{ft} / \mathrm{mi}$ in the delta.
If the width of the flow path in the delta described in Savoca and others (2009b) is about $5 \mathrm{mi}$, and the saturated thickness (about $300 \mathrm{ft}$ ) and calibrated horizontal hydraulic conductivity $(5.0 \mathrm{ft} / \mathrm{d})$ of the alluvial deposits in the delta are equivalent to the alluvial and recessional outwash aquifer (HUF unit 1), then the flow across the delta (the product of these estimates) is 168 acre-ft/yr, which is within an order of magnitude of the simulated ouflow to the delta of 384 acre-ft/yr.

A comparison of the measured and simulated groundwater discharge to streams (baseflow) in the tributary subbasins was based on synoptic stream baseflow measurements conducted in August 2007 and June 2008 (Savoca and others, 2009a). Time-averaged areaweighted groundwater-discharge values were computed for each tributary subbasin (Savoca and others, 2009a, table 7), and these values were compared to simulated groundwater-discharge values (figure 12). Simulated values of groundwater discharge to streams exceed measured values in East Fork Nookachamps, Nookachamps, and Carpenter Creek subbasins. These results are not unexpected because the steady-state model was designed to simulate annual average conditions, such as recharge, well withdrawals, and groundwater levels. Baseflow conditions in the study area typically occur during July and August (Savoca and others, 2009a) when recharge and groundwater levels are lower than the annual average, and well withdrawals are higher (Savoca and others, 2009a, fig. 24; this report fig. 7). Baseflow conditions are not well represented in the steady-state model, and simulated values of groundwater discharge to streams more closely reflect average annual conditions. The model simulates a net loss of streamflow in Fisher Creek subbasin (fig. 12); however, small net gains were measured during synoptic stream baseflow measurements (Savoca and others, 2009a).

\section{Assessment of Transient Calibration}

The results of the transient calibration were assessed by comparing measured and simulated quantities (such as groundwater levels and stream baseflows) and by examining the weighted mean of residuals, and the weighted sum of squared residuals (objective function) for monthly groundwater levels. Table 8 shows the calibration statistics for the transient calibration associated with groundwater-level measurements by HUF unit. By comparing the amount of error (percentage of the objective function) with the weight of the groundwater-level measurements (by HUF unit), it is possible to determine how well the model simulates measured values (fit) for each HUF unit. The best fit for simulated and measured groundwater-level values occurred in HUF units 4, 5, and 13; the worst fit occurred in HUF units 9, 10, and 1. HUF units 4, 2, and 10 had the lowest weighted mean residual. 


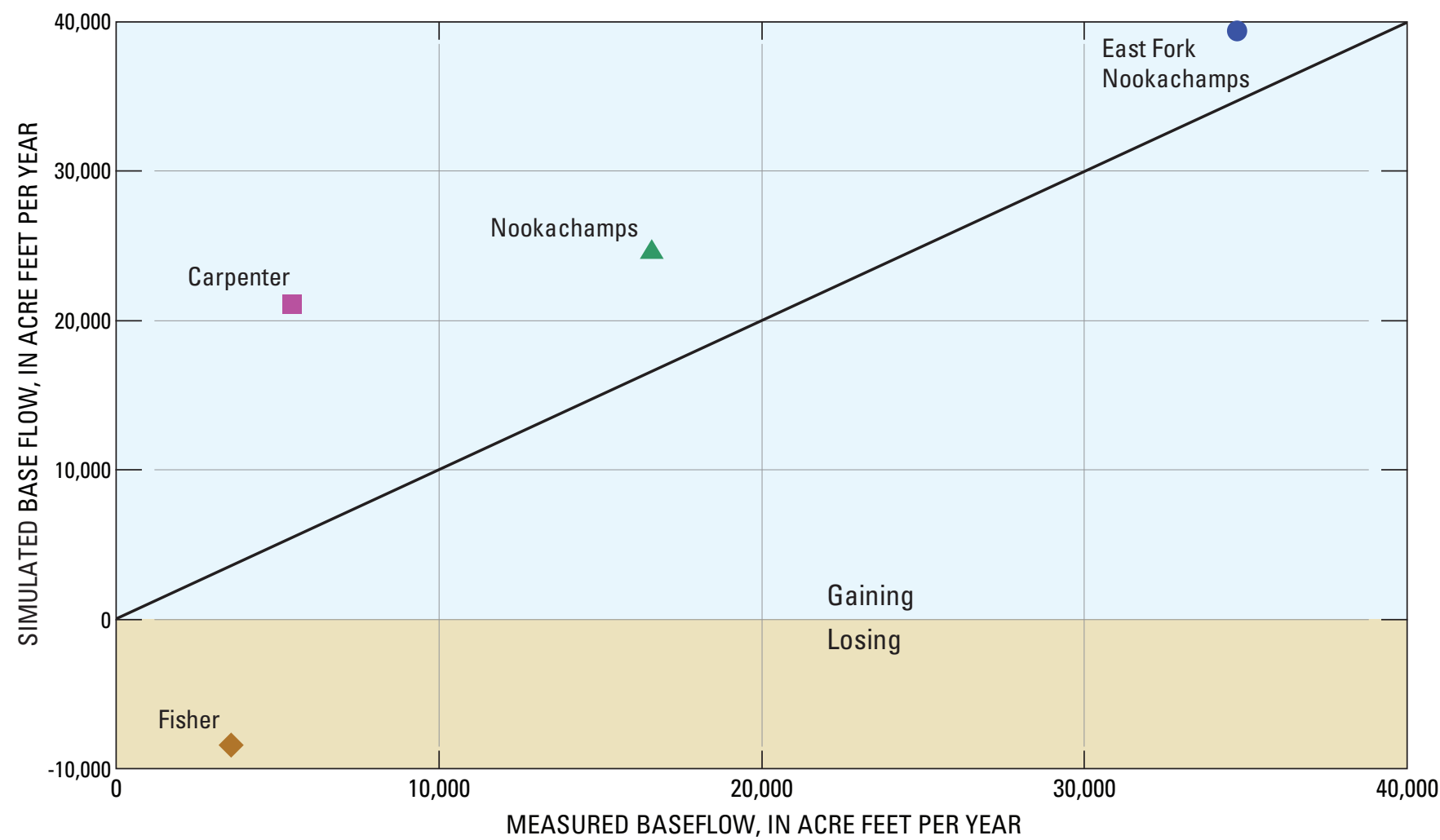

Figure 12. Simulated and measured streamflows for the calibrated steady-state model, tributary subbasins and vicinity, lower Skagit River basin, Washington.

Table 8. Calibration statistics for transient target water levels by HUF unit, tributary subbasins, lower Skagit River basin, Washington.

[O bjective function: In calibration process included streamflow targets, but this table includes only water level (head) targets. A bbreviations: $\mathrm{ft} / 3 / \mathrm{s}$, cubic feet per second; ft, feet]

\begin{tabular}{|c|c|c|c|c|c|c|}
\hline \multirow[b]{2}{*}{ HUF } & \multirow{2}{*}{$\begin{array}{c}\text { Count of } \\
\text { observations }\end{array}$} & \multicolumn{2}{|c|}{ Weight } & \multicolumn{2}{|c|}{ Objective function } & \multirow{2}{*}{$\begin{array}{l}\text { Weighted } \\
\text { mean of } \\
\text { residuals } \\
\text { (ft) }\end{array}$} \\
\hline & & Total & Percent & $\begin{array}{c}\text { Total } \\
\left(\mathrm{ft}^{2}\right)\end{array}$ & Percent & \\
\hline 1 & 258 & 2,146 & 19 & $4,443,660$ & 17 & +17.1 \\
\hline 2 & 115 & 1,120 & 10 & 694,037 & 3 & +5.0 \\
\hline 3 & 385 & 3,333 & 29 & 2,938,863 & 11 & +6.7 \\
\hline 4 & 39 & 383 & 3 & 16,946 & 0 & +4.7 \\
\hline 5 & 81 & 740 & 7 & 395,473 & 2 & +5.9 \\
\hline 7 & 67 & 539 & 5 & $1,757,279$ & 7 & -41.1 \\
\hline 9 & 185 & 1,584 & 14 & $9,841,922$ & 38 & -47.1 \\
\hline 10 & 114 & 1,014 & 9 & $5,225,950$ & 20 & -5.8 \\
\hline 13 & 47 & 456 & 4 & 495,572 & 2 & 14.1 \\
\hline All water levels & 1,291 & 11,315 & & $26,809,702$ & 100 & -2.2 \\
\hline
\end{tabular}


Table 9 shows the calibration statistics for the transient calibration associated with groundwater-level measurements by tributary subbasins and the Skagit River Valley. The best fit for simulated and measured groundwater-level values occurred in the Skagit River Valley and East Fork Nookachamps Creek subbasin; the worst fit occurred in Fisher Creek and Nookachamps Creek subbasins. East Fork Nookachamps Creek subbasin had the lowest weighted mean residual.

A plot of average measured versus average simulated groundwater-level altitudes values for the transient simulation period (Septmember 2006-September 2008) by HUF unit (figure 13) generally fall along a straight line (slope equal to 1.0, intercept of zero) representing perfect agreement between measured and simulated values. The magnitude of the residual (difference between measured and simulated values) is reflected in the distance of the value above or below the line. Positive residuals (measured value is greater than simulated) and negative residuals (measured value is less than simulated) plot below and above the line, respectively.

The results of the transient model were evaluated by comparing measured and simulated groundwater-level hydrographs (fig. 14). Measured water levels generally fluctuate in response to seasonal changes in recharge.
Simulated water levels also fluctuate in response to seasonal variation in recharge and, in most cases, the magnitude and timing of these fluctuations are similar to the changes in measured water levels.

The calibrated transient model also was evaluated for how well it simulated groundwater discharge to streams during baseflow conditions. A comparison of average measured and average simulated values of groundwater discharge to streams (baseflow) in the tributary subbasins was based on synoptic stream baseflow measurements for August 2007 and June 2008 (Savoca and others, 2009a). Area-weighted groundwater-discharge values were computed for each tributary subbasin and the average of these values were compared to average simulated groundwater-discharge values for August 2007 and June 2008 (fig. 15). Groundwater discharge to streams is reasonably well simulated in East Fork Nookachamps Creek and Nookachamps Creek subbasins.

Simulated values of groundwater discharge to streams exceed measured values in Carpenter Creek subbasin. The model simulates a net loss of streamflow in Fisher Creek subbasin; however, small net gains were measured during synoptic stream baseflow measurements (Savoca and others, 2009a).

Table 9. Calibration statistics for transient target water levels by HUF unit, tributary subbasins, lower Skagit River basin, Washington.

[O bjective function: In calibration process, included streamflow targets, but this table includes only water level (head) targets. A bbreviations: $\mathrm{ft} / 3 / \mathrm{s}$, cubic feet per second; ft, feet]

\begin{tabular}{|c|c|c|c|c|c|c|}
\hline \multirow[b]{2}{*}{ Basin } & \multirow{2}{*}{$\begin{array}{c}\text { Count of } \\
\text { observations }\end{array}$} & \multicolumn{2}{|c|}{ Weight } & \multicolumn{2}{|c|}{ Objective function } & \multirow{2}{*}{$\begin{array}{l}\text { Weighted } \\
\text { mean of } \\
\text { residuals } \\
\text { (ft) }\end{array}$} \\
\hline & & Total & Percent & $\begin{array}{l}\text { Total } \\
\left(\mathrm{ft} /{ }^{2}\right)\end{array}$ & Percent & \\
\hline East Fork Nookachamps & 276 & 2,415 & 21 & $3,608,575$ & 14 & -2.5 \\
\hline Main Stem Nookachamps & 344 & 2,993 & 26 & $6,628,764$ & 26 & -5.3 \\
\hline Carpenter Creek & 214 & 1,790 & 16 & $4,217,892$ & 16 & +21.2 \\
\hline Fisher Creek & 434 & 3,887 & 34 & $8,661,925$ & 34 & -5.3 \\
\hline Skagit River Valley & 23 & 230 & 2 & $2,692,546$ & 10 & +108.2 \\
\hline All water levels & 1,291 & 11,315 & & $26,809,702$ & & -2.2 \\
\hline
\end{tabular}




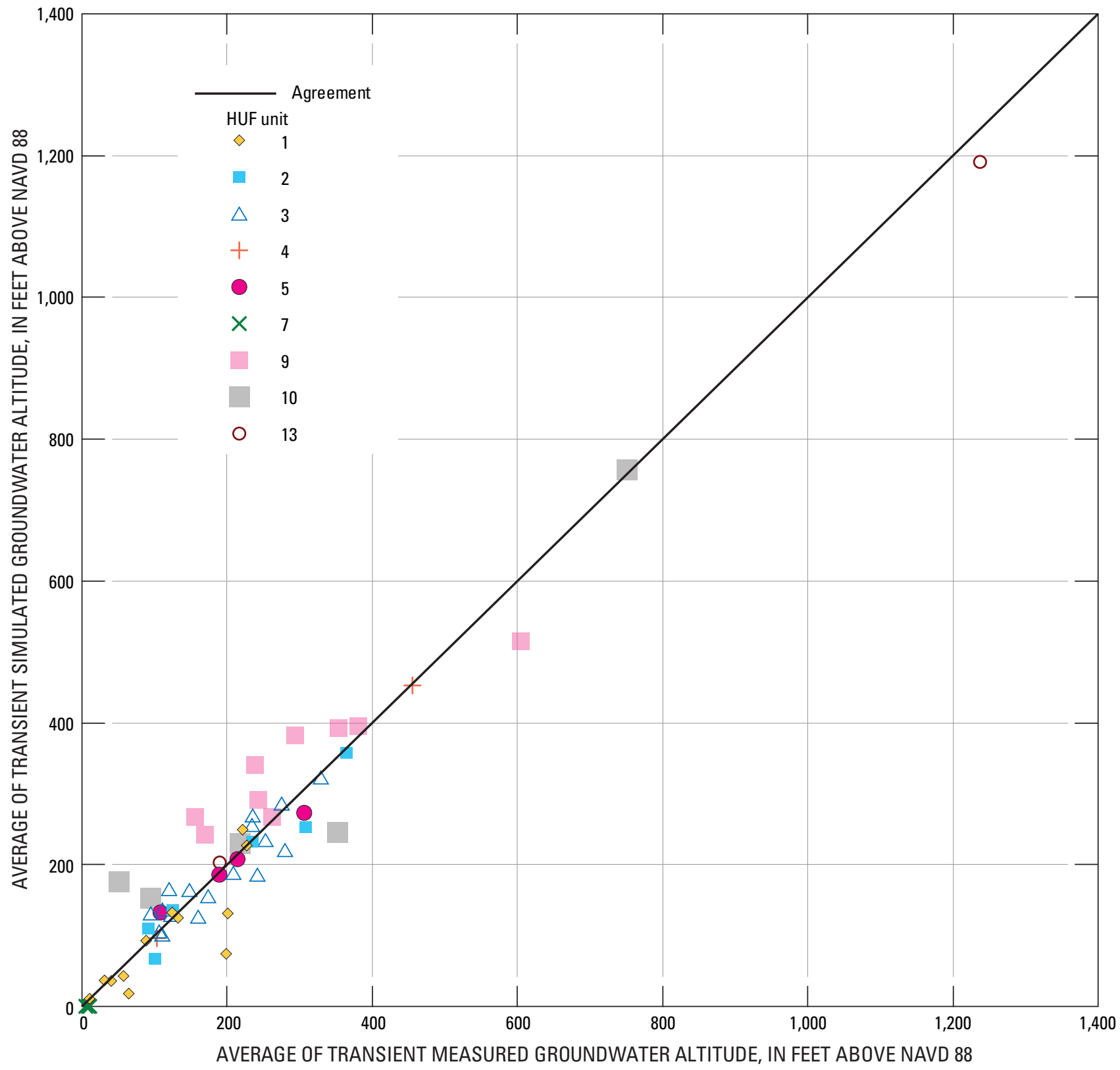

Figure 13. Average simulated and measured water-level altitudes by HUF unit for the calibrated transient model, tributary subbasins and vicinity, lower Skagit River basin, Washington. 
$A$
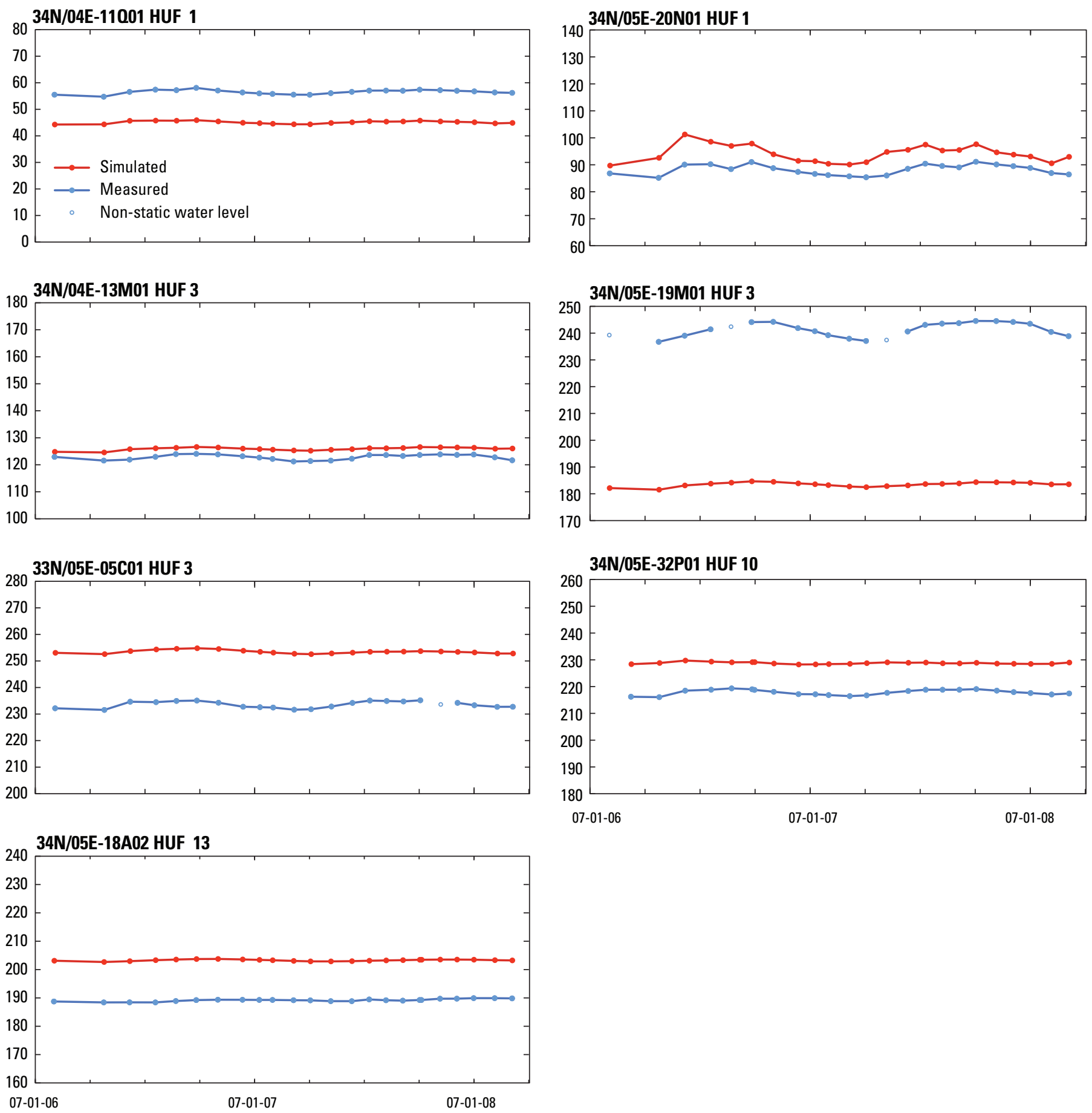

Figure 14. Simulated and measured groundwater levels, tributary subbasins and vicinity, lower Skagit River basin, Washington, September 2006-September 2008. 
B1
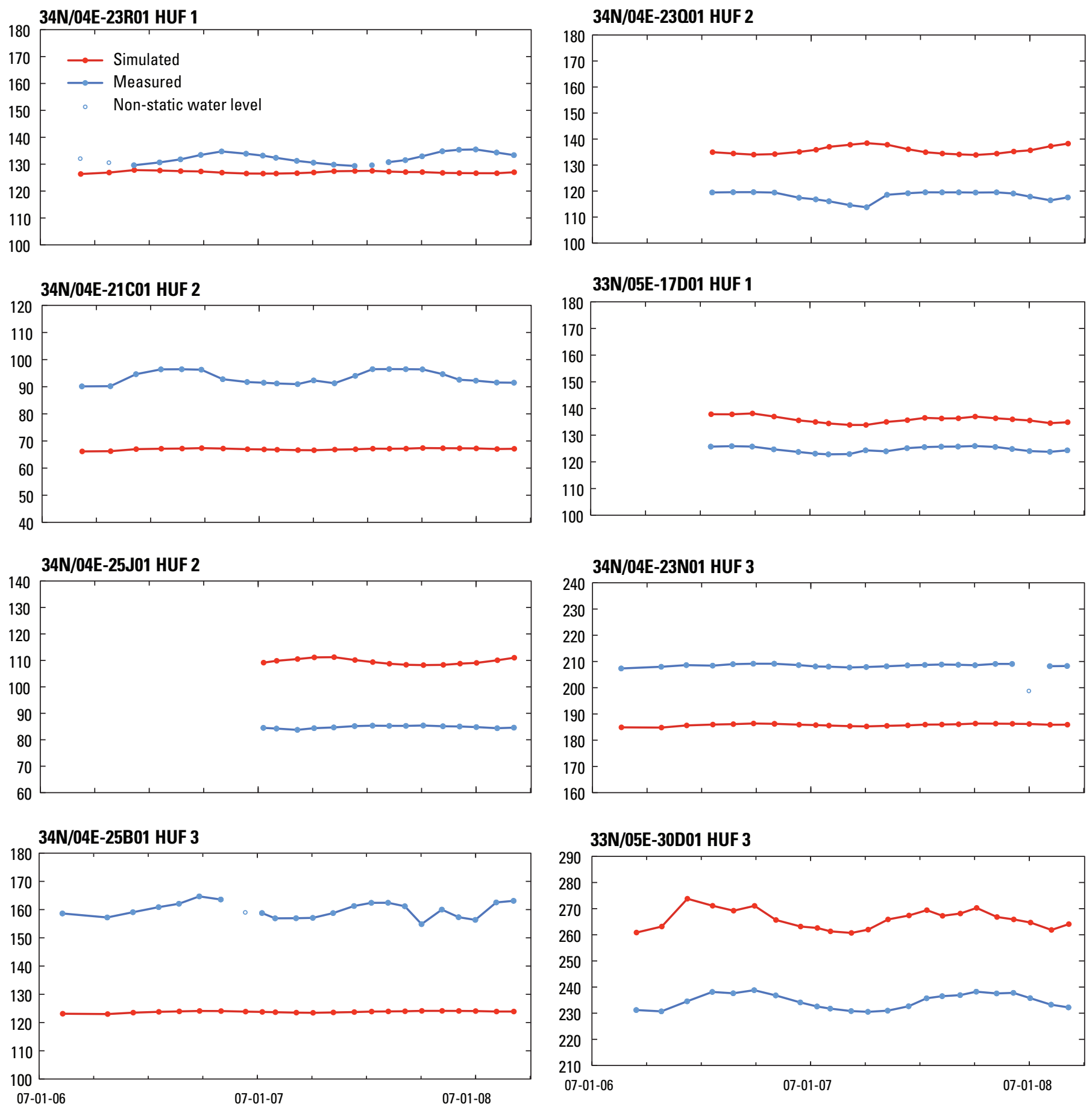

Figure 14.-Continued 
B2
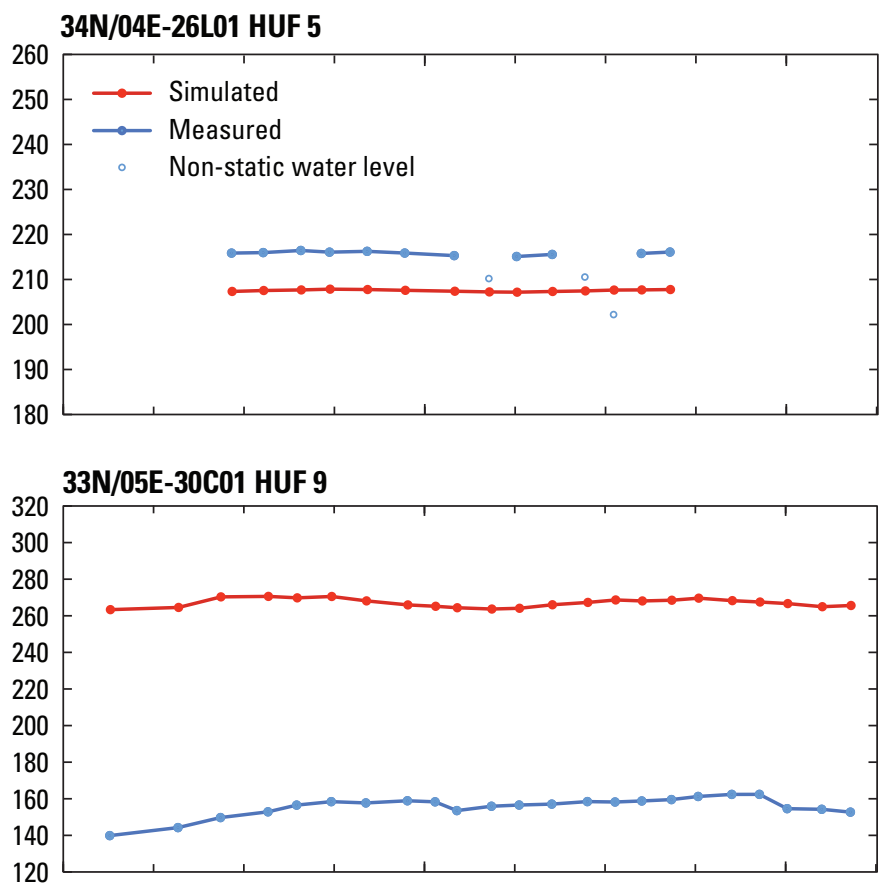

33N/04E-01G01 HUF 10

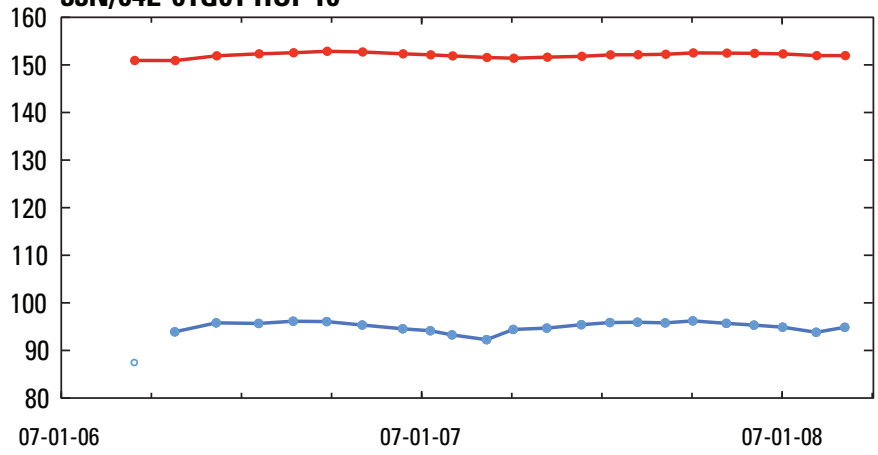

Figure 14.-Continued

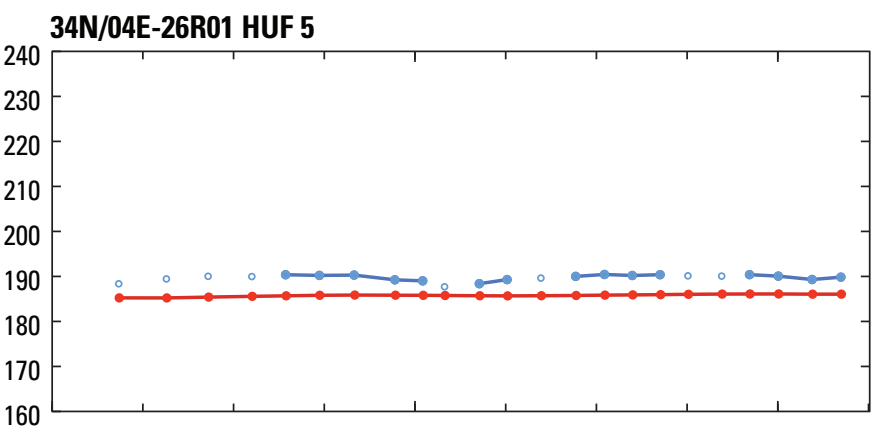

33N/04E-26A01 HUF 9

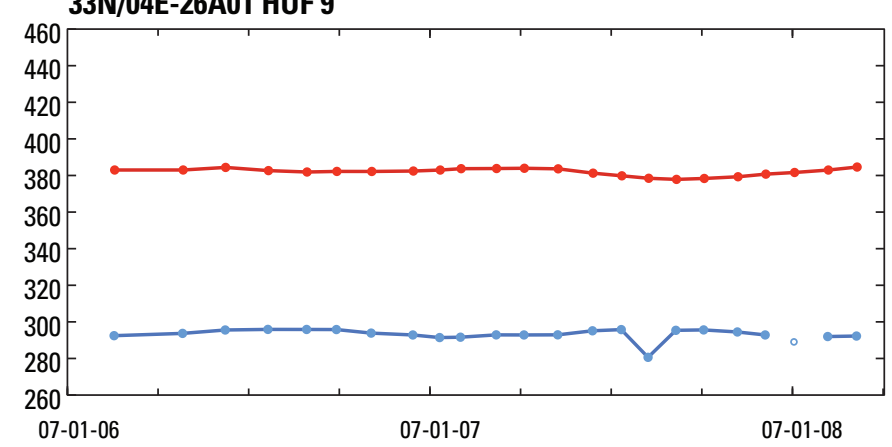


C

34N/04E-34E01 HUF 1

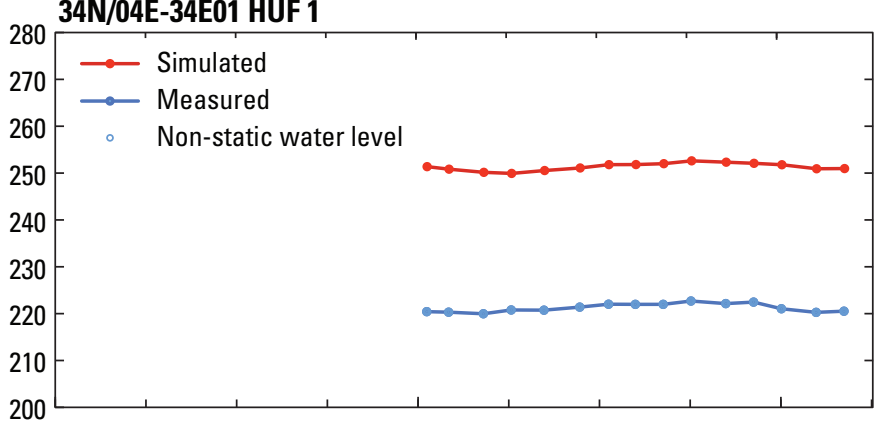

33N/04E-21N01 HUF 3

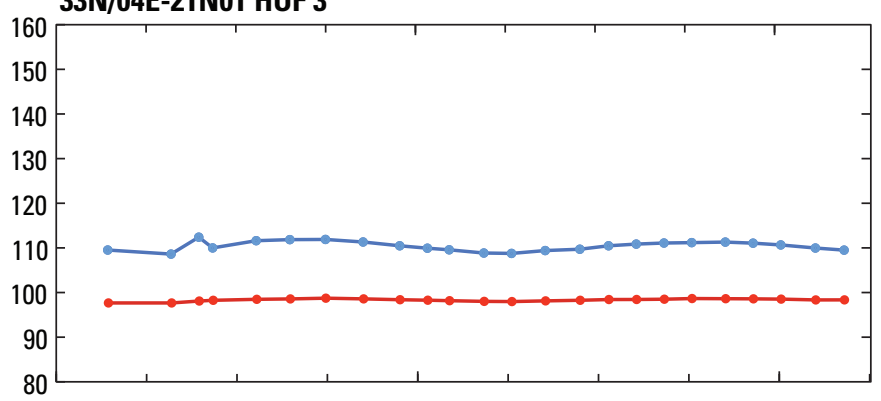

33N/04E-21H01 HUF 9

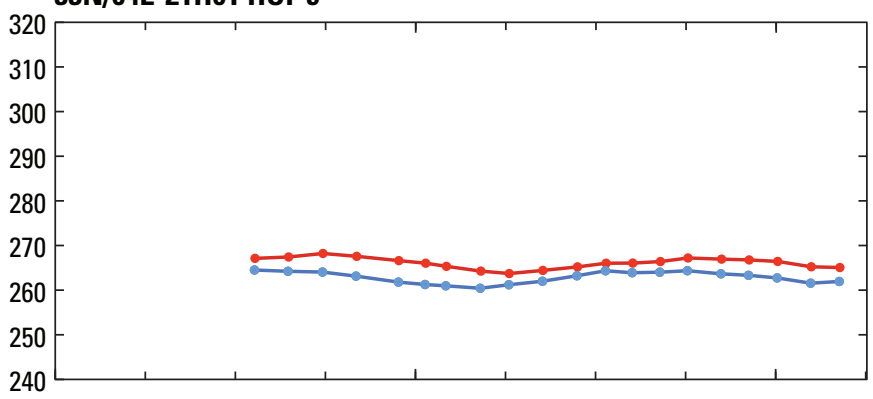

34N/04E-28K01 HUF 10

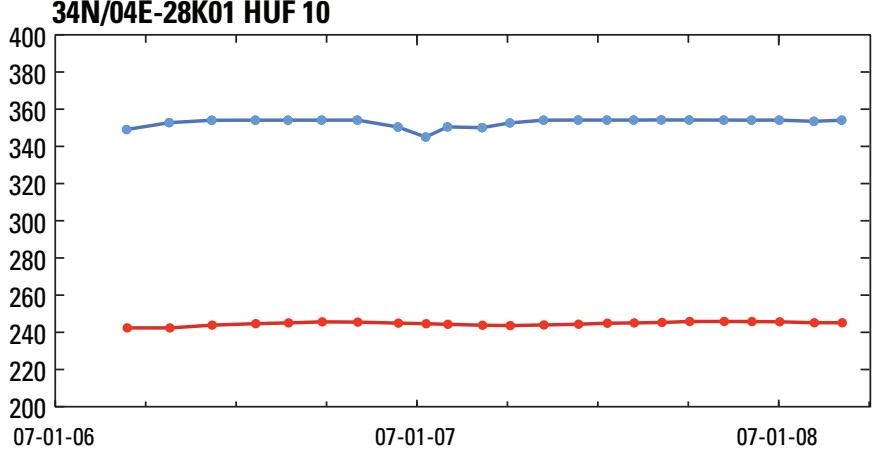

33N/04E-20J01 HUF 1

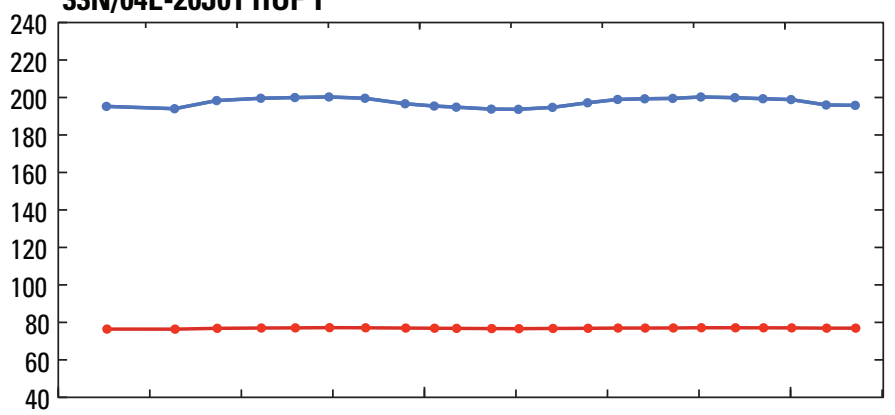

32N/04E-04N01 HUF 3

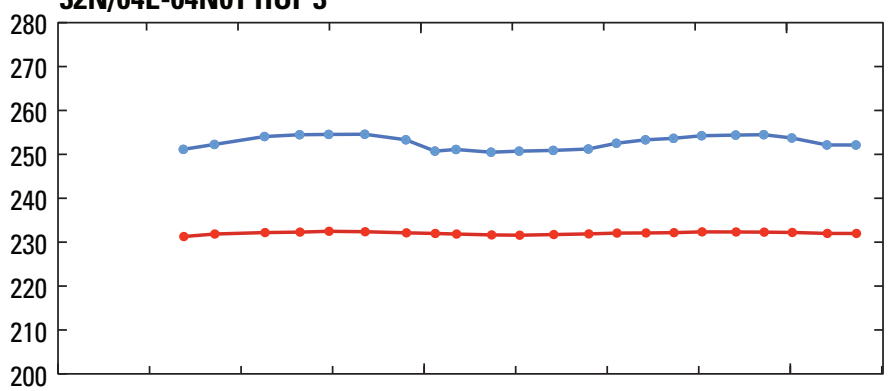

33N/04E-02M01 HUF 10

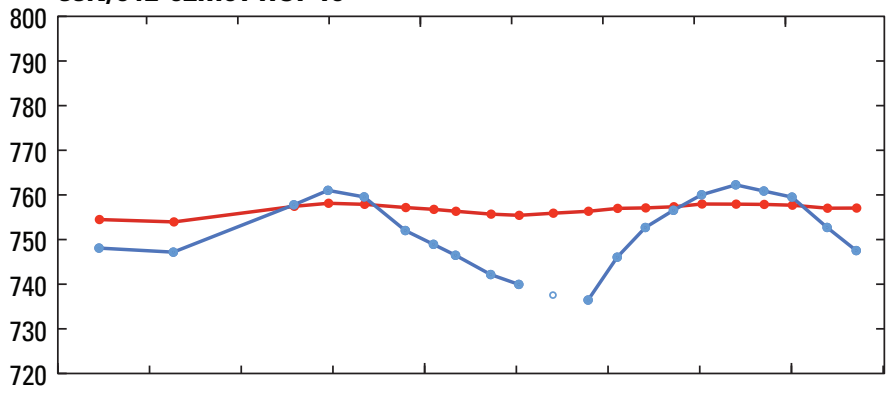

33N/04E-03P01 HUF 13

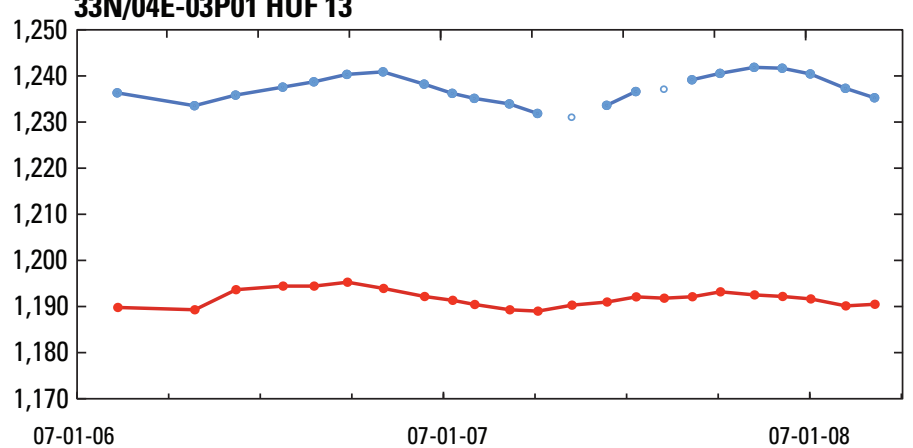

Figure 14.-Continued 
D1

32N/04E-05G01 HUF 1
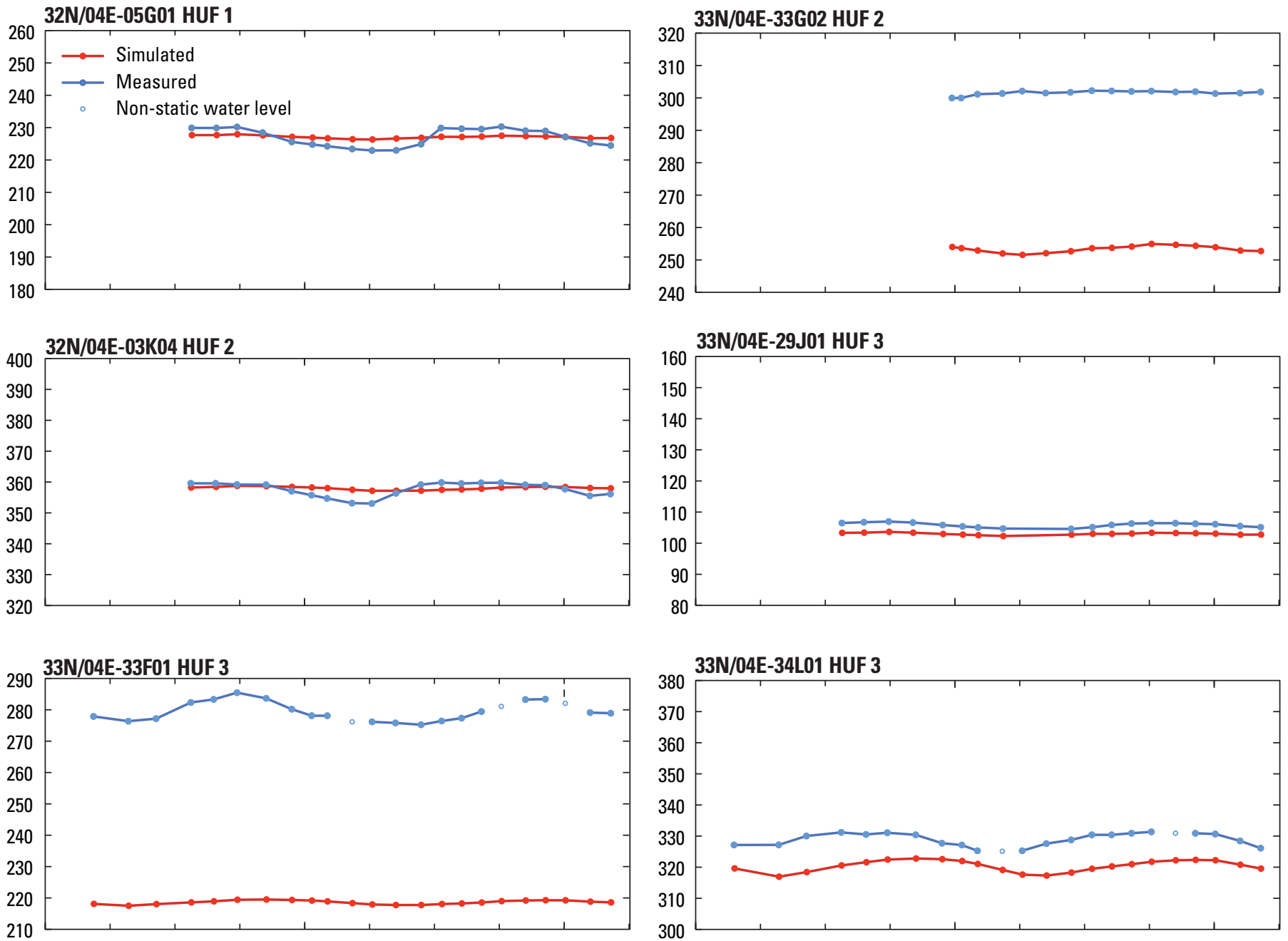

33N/04E-34L01 HUF 3

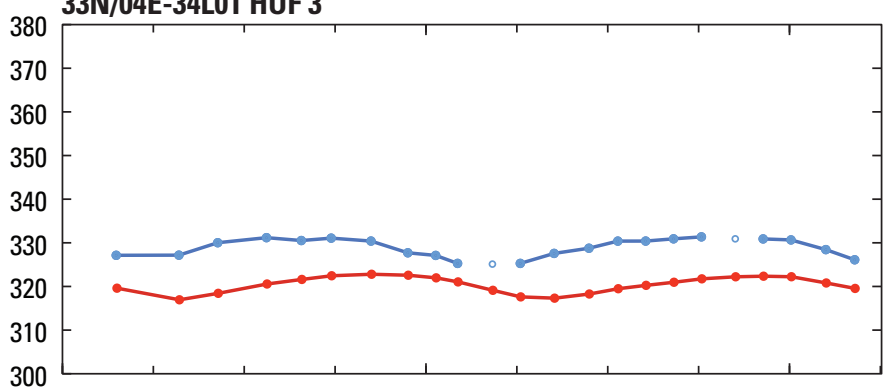

32N/04E-04H01 HUF 3
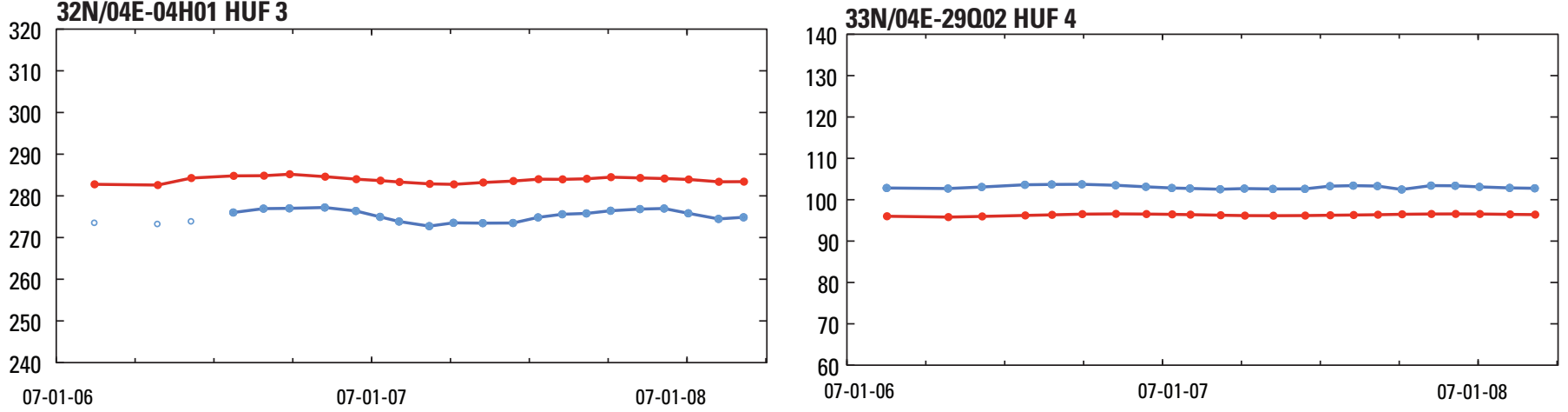

Figure 14.-Continued 
D2
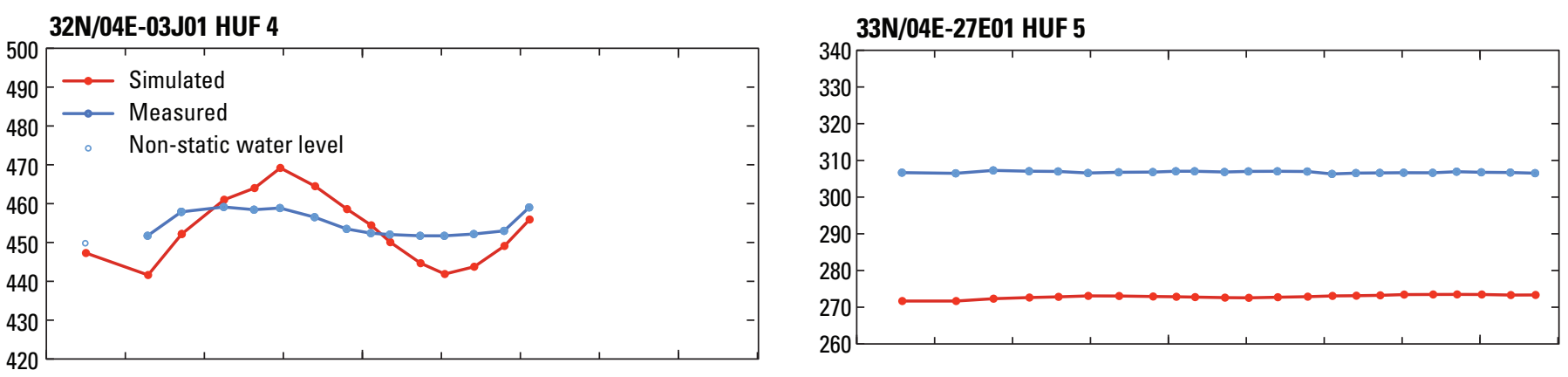

\section{N/04E-28M01 HUF 5}
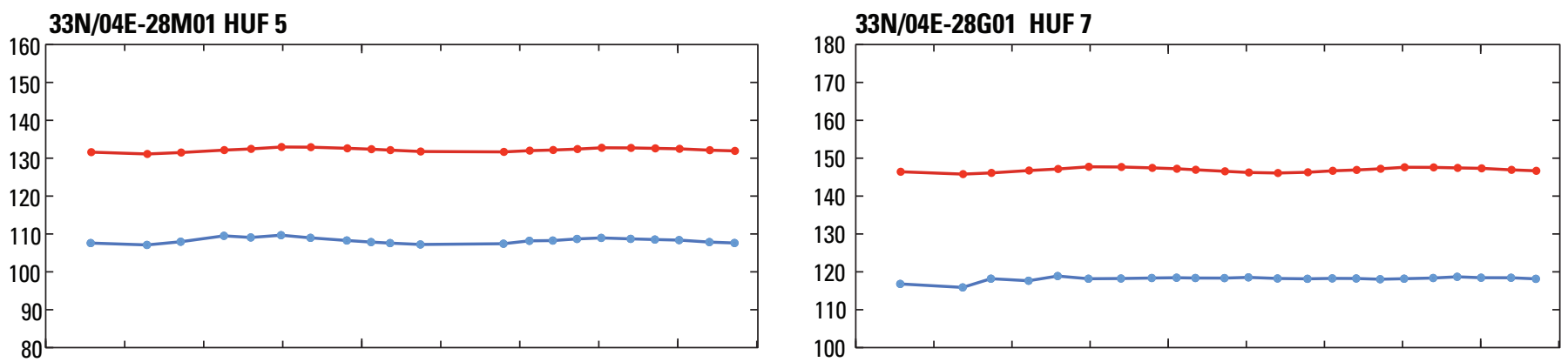

33N/04E-27F01 HUF 9

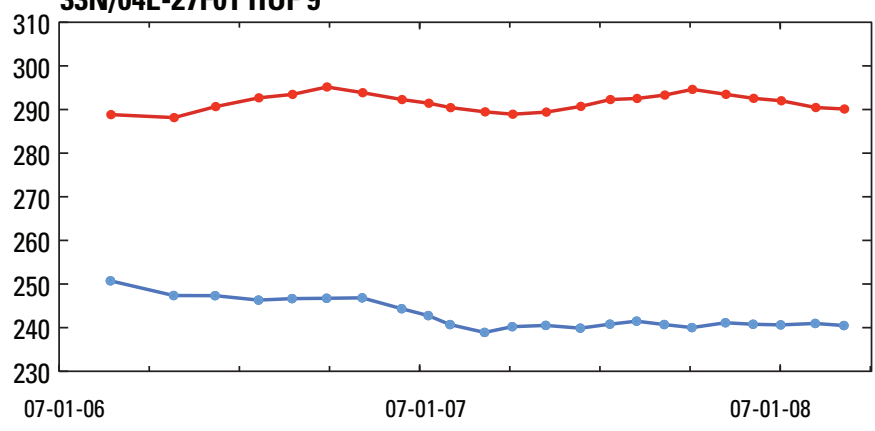

Figure 14.-Continued

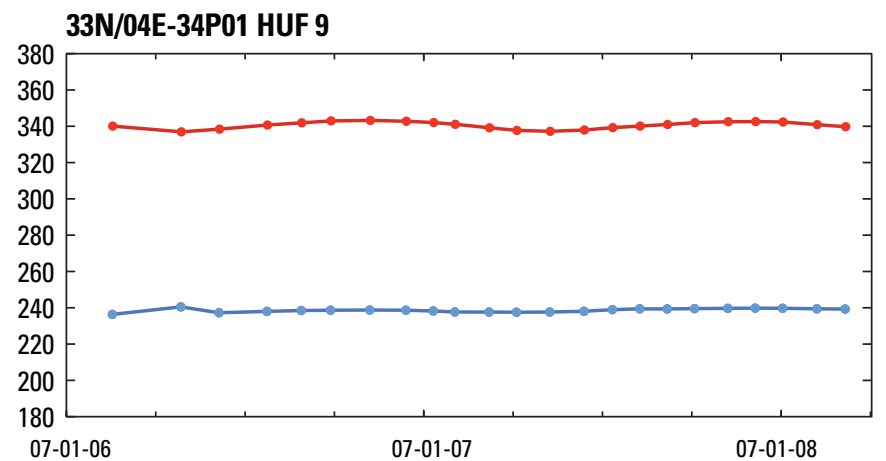




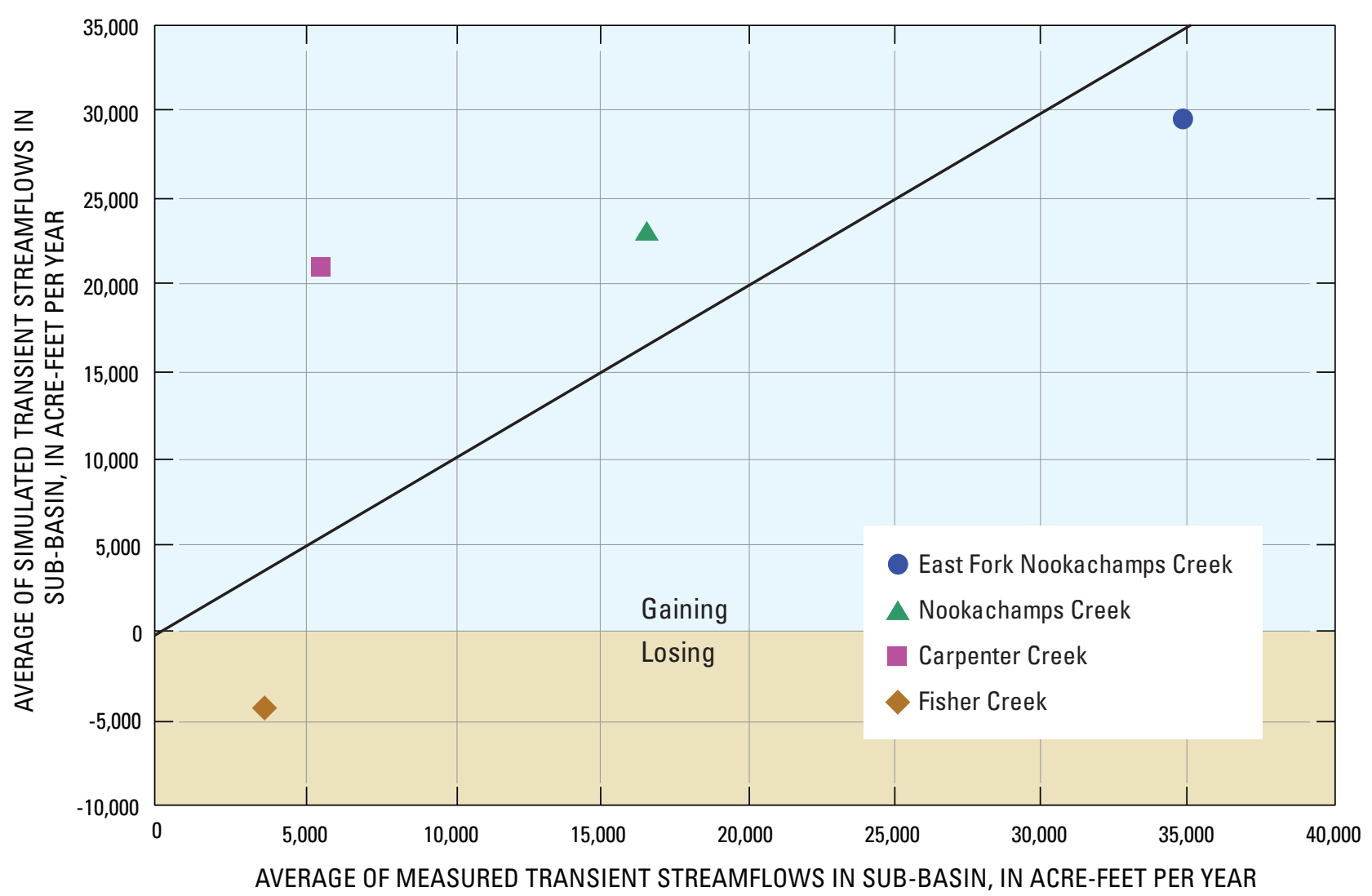

Figure 15. Simulated and measured stream baseflows for East Fork Nookachamps, Nookachamps, Carpenter, and Fisher Creeks, lower Skagit River basin, Washington, August 2007 and June 2008.

\section{Model Limitations}

The model presented in this report is a simplified mathematical representation of the complex natural groundwater-flow system in tributary subbasins of the lower Skagit River. Intrinsic to the model is the error and uncertainty associated with the approximations, assumptions, and simplifications that must be made. Although the model provides a relatively good fit between simulated and measured or estimated quantities, indicating that the overall simulated groundwater flow is a reasonable representation of groundwater flow in the tributary subbasins, the model is subject to limitations. In general, because of model scale and level of detail, the model is most applicable to analysis of groundwater issues at the subbasin scale. Local-scale heterogeneity in hydrologic properties, recharge, and discharge are not adequately represented by the regional-scale groundwater-flow model constructed for this study.

The data used to construct and calibrate the model reflect short-term conditions (August 2006-September 2008) and likely do not represent the full range of hydrologic and anthropogenic variability within the system. Boundary conditions and the representation of various components of the flow system that were appropriate for the calibrated range of conditions may be inappropriate for model simulations when conditions in the groundwater system are beyond the range used during calibration. There is no long-term ambient groundwater monitoring network in the study area, and data from the short-term (October 2006-September 2008) monthly monitoring network established for this study (fig. 14) are insufficient to evaluate water-level trends relating to long-term changes in groundwater storage, and test the assumption of steady-state conditions.

The model simulates groundwater flow in sedimentary, igneous, and metamorphic units (table 1) containing secondary permeability features (joints and fractures) as a porous medium rather than as a fracture flow system. Determining the location and hydraulic effectiveness of these features was beyond the scope of this study, and the distribution and effectiveness of secondary permeability features in the model area is assumed to be highly variable. The simplified representation of a heterogeneous fracture flow system as a homogeneous porous medium in the model prevents the accurate simulation of the flow through secondary 
permeability features that likely influence the direction and quantity of groundwater flow on a local scale. This may cause inaccuracies in the simulation of water levels and water-level changes within sedimentary and bedrock units and adjacent unconsolidated units, as well as the simulation of groundwater discharge to streams in areas underlain by units containing secondary permeability features.

Measurement-based estimates of recharge were not available for the study area. The distribution of recharge from precipitation in the study area was estimated by applying regional precipitation-recharge relations based on regression equations for unconsolidated glacial deposits in other areas of Puget Sound. In addition, considerable uncertainty exists regarding precipitation-recharge relations for sedimentary and bedrock units, which are exposed at land surface over much of the model area. The lack of available public supply, residential, and crop irrigation well withdrawal data (very few wells have flow gages installed or read) required the use of per-capita and crop irrigation requirement water-use estimates. Uncertainty also exists regarding estimates of residential return flows to the aquifer through septic system drain fields, and outdoor (irrigation) use.

\section{Model Applications}

The calibrated model can be used to derive components of the groundwater budget or estimate the response of the regional system to new stresses, such as increased groundwater withdrawals. Water-resource managers can use this information to make informed decisions to plan for future groundwater development. The uncertainty associated with inaccuracies in the groundwater-flow model is carried forward to the model applications.

\section{Model-Derived Groundwater Budget}

A groundwater budget for average conditions during the study period (September 1, 2006-August 31, 2008) in the model area is expressed by the following equation:

$$
\mathrm{GW}_{\text {in }}+\mathrm{R}=\mathrm{GW}_{\text {out }}+\mathrm{D}+\Delta \mathrm{S}
$$

where

$\mathrm{GW}_{\text {in }}$ is groundwater inflow to the model area,

$\mathrm{GW}_{\text {out }}$ is groundwater outflow from the model area,

$\mathrm{R}$ is recharge,

$\mathrm{D}$ is discharge, and

$\Delta \mathrm{S}$ is change in groundwater storage.
Recharge to the groundwater system occurs primarily as precipitation and seepage from streams and lakes.

Secondary recharge occurs as seepage from septic systems and deep percolation of irrigation water. Discharge from the groundwater system occurs as seepage to streams and lakes, as evaporation of groundwater from soils and transpiration from plants, as groundwater outflow, and as withdrawals from wells. A more detailed representation of the groundwater budget of the model area is provided by the equation:

$$
\begin{aligned}
\mathrm{GW}_{i n}+\mathrm{R}_{p p t}+\mathrm{R}_{s w}+\mathrm{R}_{s e c}=\mathrm{GW}_{\text {out }}+ & \mathrm{D}_{s w}+\mathrm{D}_{e t} \\
& +\mathrm{D}_{p p g}+\Delta \mathrm{S},
\end{aligned}
$$

where

$$
\begin{aligned}
& \mathrm{R}_{p p t} \text { is recharge from precipitation, } \\
& \mathrm{R}_{s w} \text { is recharge from streams and lakes, } \\
& \mathrm{R}_{s e c} \text { is secondary recharge, } \\
& \mathrm{D}_{s w} \text { is discharge to streams and lakes, } \\
& \mathrm{D}_{e t} \text { is groundwater discharge by } \\
& \quad \text { evapotranspiration, and } \\
& \mathrm{D}_{p p g} \text { is withdrawals from wells. }
\end{aligned}
$$

All water-budget components can be quantified on the basis of the calibrated steady-state model except discharge by evapotranspiration and change in groundwater storage. Net recharge was used; therefore, water lost to the system through direct evapotranspiration of groundwater is largely taken into account and Det is assumed to be zero. Inflow to the system is assumed to be equal to outflow from the system under steady-state conditions, resulting in no change in the volume of water stored within the system $(\Delta S=0)$. Substituting the calibrated-model values and above assumptions into equation 6 yields the following:

\begin{tabular}{|l|l|l|c|}
\hline \multicolumn{1}{|c|}{ In } & \multicolumn{1}{|c|}{$\begin{array}{c}\text { Rate } \\
\text { (acre-ft//r) }\end{array}$} & \multicolumn{1}{c|}{ Out } & $\begin{array}{c}\text { Rate } \\
\text { (acre-ft/yr) }\end{array}$ \\
\hline $\mathrm{GW}_{\text {in }}$ & 10 & $\mathrm{GW}_{\text {out }}$ & 384 \\
\hline $\mathrm{R}_{p p t}$ & 142,933 & $\mathrm{D}_{s w}$ & 166,508 \\
\hline $\mathrm{R}_{s w}$ & 32,687 & $\mathrm{D}_{e t}$ & $\begin{array}{c}\text { Not calculated } \\
\text { in model }\end{array}$ \\
\hline $\mathrm{R}_{\text {sec }}$ & 1,100 & $\mathrm{D}_{p p q}$ & 9,842 \\
\hline Total In & 176,730 & Total Out & 176,734 \\
\hline
\end{tabular}

The calibrated groundwater model budget can be used to make general observations about the flow system. 
Total flow through the groundwater system was about 176,730 acre-ft/yr in the study area. Precipitation was the primary source of water recharging the groundwater system (81 percent); recharge from streams and lakes was about 19 percent of the total recharge. Groundwater discharge to streams and lakes was 166,500 acre-ft/yr, or 94 percent of the total discharge from the groundwater system. Withdrawals from wells were about 6 percent of discharge. Savoca and others (2009a) reported an estimated total groundwater discharge from the tributary subbasins of 92,400 acre-ft/yr; most of this discharge (65 percent) was to streams (60,400 acre-ft/yr) and 32 percent $(29,800$ acre-ft/yr) was estimated to flow out of the subbasins to the Skagit River Valley. Model-derived groundwater flows for the subbasins (table 10) indicate a total groundwater discharge from the tributary subbasins of 93,084 acre-ft/yr; most of this discharge (82 percent) was to streams (76,741 acre-ft/yr) and 15 percent
$(14,142$ acre-ft/yr) was estimated to flow out of the subbasins to the Skagit River Valley. Model-derived subbasin groundwater flows are considered reasonable when compared to estimates from Savoca and others (2009a).

The water budget for the transient simulation period (September 2006-September 2008) is presented in the section, "Model Simulations") and indicates a change in groundwater storage during the transient simulation period of 5,027 acre-ft/ yr, or about 5 percent of the precipitation recharge. This change in storage suggests that "true" steadystate conditions may not have been reached during steady-state calibration. However, there is no long-term ambient groundwater monitoring network in the study area, and data from the shortterm (October 2006-September 2008) monthly monitoring network established for this study (fig. 14) are insufficient to evaluate water-level trends relating to long term changes in groundwater storage.

Table 10. Model-derived groundwater flow, tributary subbasins and vicinity, lower Skagit River basin, Washington.

[Net flows equal inflow minus outflow; negative flows are out of the groundwater system or out of the subbasin. Column entries may not add exactly due to rounding. A bbreviation: acre-ft/yr, acre-foot per year]

\begin{tabular}{|c|c|c|c|c|c|c|}
\hline & \multicolumn{6}{|c|}{ Net flows (acre-ft/yr) } \\
\hline & $\begin{array}{c}\text { East Fork } \\
\text { Nookachamps }\end{array}$ & Nookachamps & Carpenter & Fisher & $\begin{array}{c}\text { All tributary } \\
\text { subbasins }\end{array}$ & Skagit Valley \\
\hline Recharge & 41,324 & 23,842 & 17,482 & 10,433 & 93,081 & 50,800 \\
\hline Withdrawals from wells & -21 & -210 & $-1,840$ & -130 & $-2,201$ & $-7,641$ \\
\hline Rivers and Lakes & $-39,383$ & $-24,746$ & $-21,084$ & 8,472 & $-76,741$ & $-56,288$ \\
\hline Skagit Bay & 0 & 0 & 0 & 0 & 0 & -630 \\
\hline Skagit Delta & 0 & 0 & 0 & 0 & 0 & -384 \\
\hline Total Interbasin flow & $-1,921$ & 1,113 & 5,442 & $-18,776$ & $-14,142$ & 14,142 \\
\hline To East Fork Nookachamps & NA & 1,343 & 0 & 0 & NA & 578 \\
\hline To Nookachamps & $-1,343$ & NA & -536 & $-1,857$ & NA & 2,623 \\
\hline To Carpenter & 0 & 536 & NA & $-8,021$ & NA & 2,042 \\
\hline To Fisher & 0 & 1,857 & 8,021 & NA & NA & 8,898 \\
\hline To Skagit Valley & -578 & $-2,623$ & $-2,042$ & $-8,898$ & $-14,142$ & NA \\
\hline
\end{tabular}




\section{Model Simulations}

The groundwater flow model was used to simulate possible effects on water levels and discharge components of the water budget caused by changes in well withdrawals and recharge. These model simulations were selected to demonstrate model performance and to show how the model might be used to investigate water-resource issues. Model simulation results were compared to "base simulation" results that represent calibrated steady-state or transient model conditions prior to modification for simulations. Examples of simulation-derived water-level change maps are provided for the advance outwash aquifer (Qga, HUF unit 3) to illustrate model capabilities for all HUF units. Model simulations were conducted to evaluate the following conditions:

Simulation 1. Increase current withdrawals by 50 percent along with corresponding increases in return flows in residential wells in Nookachamps Creek subbasin under steady-state conditions. Increased withdrawals are applied only in areas where new residential wells are likely, not in existing public supply water service areas, within city limits, or in sewer district boundaries where no off-setting return flows would occur. Compare simulation results to "base simulation" (table 11 and fig. 16).

Simulation 2. Increase current residential withdrawals by the same total amount in simulation 1 (with corresponding increases in return flows) in areas where new residential wells are likely, but distribute that amount only in deeper wells within Nookachamps Creek subbasin under steady-state conditions. Deeper wells were simulated by assigning withdrawal amounts to the next lowest unconsolidated aquifer, or if necessary, the underlying sedimentary or bedrock unit. Wells already located in sedimentary or bedrock units were not “deepened”. Compare simulation results to "base simulation” (table 11 and fig. 17).

Table 11. Comparison of selected water budget components for the "base simulation" steady-state condition and simulations 1 and 2 , Nookachamps subbasin, lower Skagit River basin, Washington.

[Subbasin netflow equals subbasin inflow minus subbasin outflow. Column entries may not add exactly due to rounding. Abbreviation: acre-ft/yr, acre-foot per year]

\begin{tabular}{|c|c|c|c|c|c|c|c|}
\hline $\begin{array}{l}\text { Nookachamps } \\
\text { subbasin }\end{array}$ & $\begin{array}{c}\text { Base simulation } \\
\text { (acre-ft/yr) }\end{array}$ & $\begin{array}{c}\text { Simulation } 1 \\
\text { (acre-ft/yr) }\end{array}$ & $\begin{array}{c}\text { Change } \\
\text { (acre-ft/yr) }\end{array}$ & $\begin{array}{c}\text { Percent of } \\
\text { change in } \\
\text { consumptive } \\
\text { use }\end{array}$ & $\begin{array}{l}\text { Simulation } 2 \\
\text { (acre-ft/yr) }\end{array}$ & $\begin{array}{c}\text { Change } \\
\text { (acre-ft/yr) }\end{array}$ & $\begin{array}{c}\text { Percent of } \\
\text { change in } \\
\text { consumptive } \\
\text { use }\end{array}$ \\
\hline \multicolumn{8}{|l|}{ Water budget component } \\
\hline Precipitation recharge & 23,684 & 23,684 & 0 & & 23,684 & 0 & \\
\hline Return flows & 158 & 236 & 78.8 & & 236 & 78.8 & \\
\hline Change in consumptive use & & & +23.3 & 100 & & +23.3 & 100 \\
\hline Discharge to streams (net) & 24,746 & 24,725 & -21.5 & -92 & 24,725 & -21.5 & -92 \\
\hline Subbasin inflow & 7,761 & 7,762 & +1.0 & +4 & 7,762 & +1.3 & +5 \\
\hline Subbasin outflow & 6,648 & 6,647 & -1.0 & -4 & 6,647 & -1.1 & -5 \\
\hline Subbasin netflow & 1,113 & 1,115 & +2.0 & +9 & 1,115 & +2.3 & +10 \\
\hline
\end{tabular}

\footnotetext{
${ }^{1}$ Includes withdrawals from public supply, residential, and crop irrigation wells.
} 


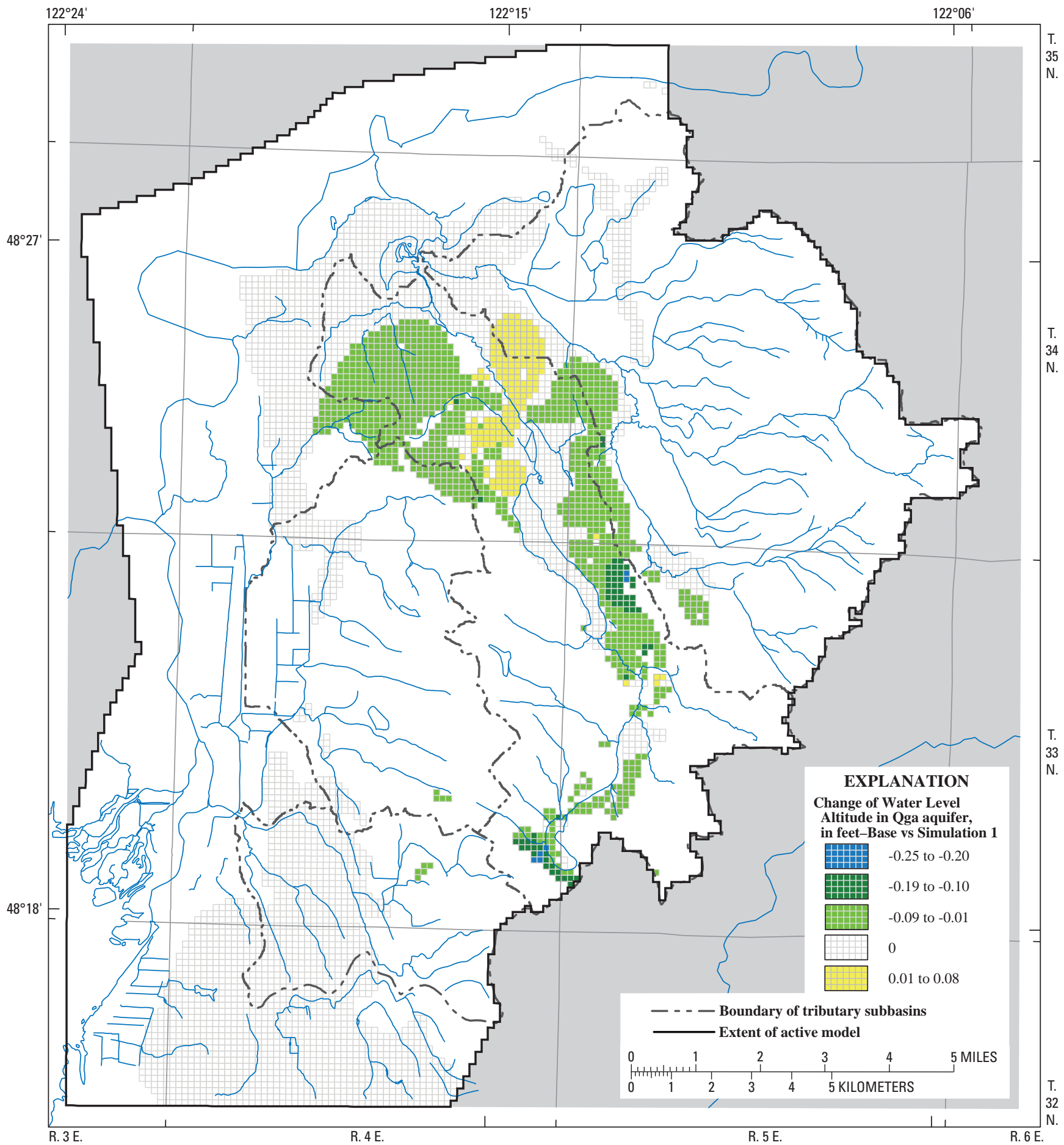

Figure 16. Simulated groundwater-level altitude change between the steady-state "base simulation" and simulation 1, tributary subbasins and vicinity, lower Skagit River basin, Washington. 


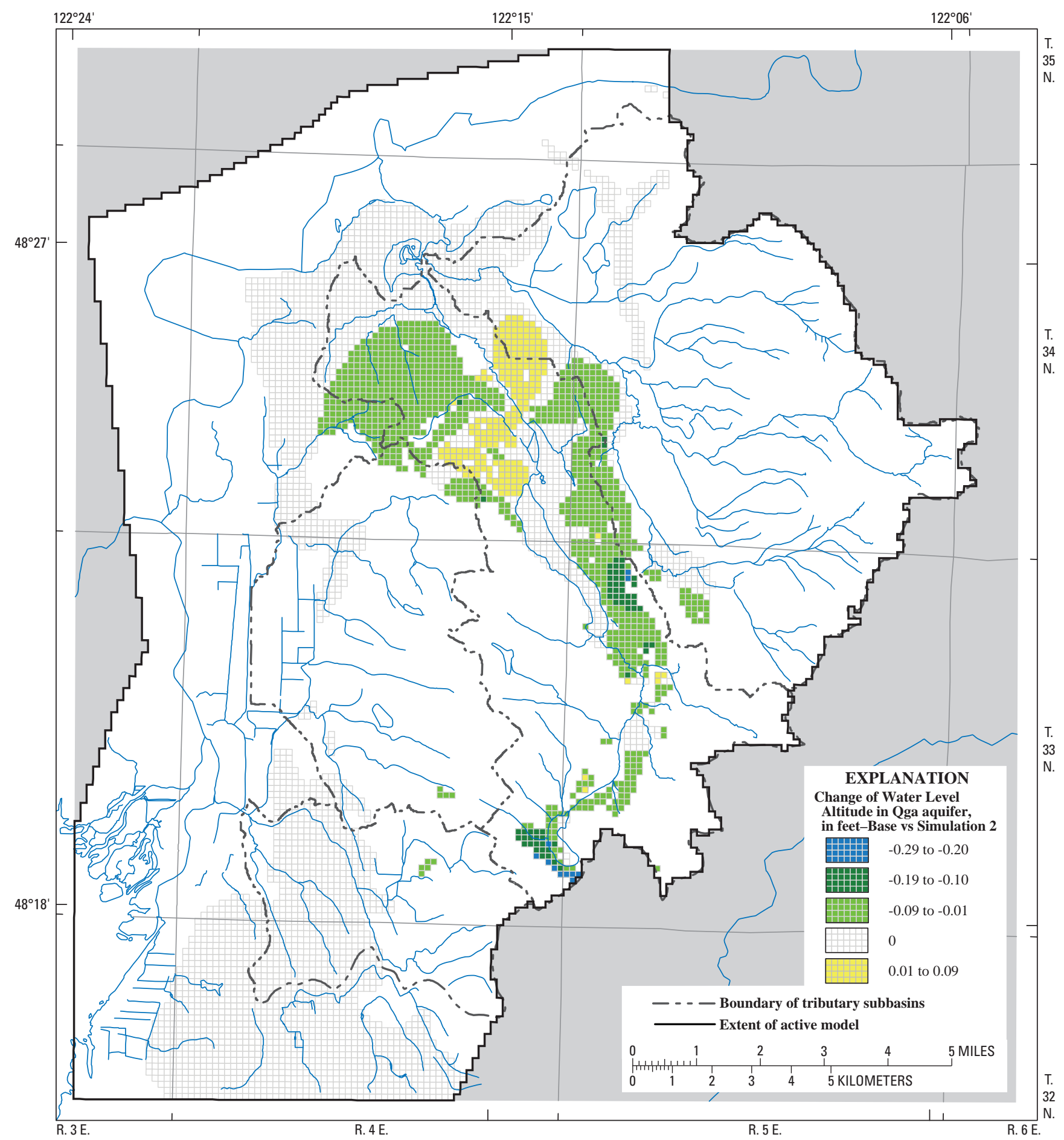

Figure 17. Simulated groundwater-level altitude change between the steady-state "base simulation" and simulation 2 , tributary subbasins and vicinity, lower Skagit River basin, Washington. 
Simulation 3. Increase current residential withdrawals by 50 percent along with corresponding increases in return flows in areas where new residential wells are likely, within all four tributary subbasins under steady-state conditions. Compare simulation results to "base simulation" (table 12 and fig. 18).
Simulation 4. Increase current residential withdrawals by the same total amount in simulation 3 (with corresponding increases in return flows) in areas where new residential wells are likely, but distribute that amount only in deeper wells in all four tributary subbasins under steady-state conditions. Compare simulation results to "base simulation" (table 12 and fig. 19).

Table 12. Comparison of selected water budget components for the "base simulation" steady-state condition and simulations 3 and 4 , tributary subbasins, lower Skagit River basin, Washington.

[Subbasin net flow equals subbasin inflow minus subbasin outflow. Column entries may not add exactly due to rounding. A bbreviation: acre-ft/yr, acre-foot per year]

\begin{tabular}{|c|c|c|c|c|c|c|c|}
\hline $\begin{array}{l}\text { All tributary } \\
\text { subbasins }\end{array}$ & $\begin{array}{l}\text { Base simulation } \\
\text { (acre-ft/yr) }\end{array}$ & $\begin{array}{c}\text { Simulation } 3 \\
\text { (acre-ft/yr) }\end{array}$ & $\begin{array}{c}\text { Change } \\
\text { (acre-ft/yr) }\end{array}$ & $\begin{array}{c}\text { Percent of } \\
\text { change in } \\
\text { consumptive } \\
\text { use }\end{array}$ & $\begin{array}{l}\text { Simulation } 4 \\
\text { (acre-ft/yr) }\end{array}$ & $\begin{array}{c}\text { Change } \\
\text { (acre-ft/yr) }\end{array}$ & $\begin{array}{c}\text { Percent of } \\
\text { change in } \\
\text { consumptive } \\
\text { use }\end{array}$ \\
\hline \multicolumn{8}{|l|}{ Water budget component } \\
\hline Precipitation recharge & 92,636 & 92,636 & 0 & & 92,636 & 0 & \\
\hline Return flows & 445 & 668 & 223 & & 668 & 223 & \\
\hline Discharge to streams (net) & 76,741 & 76,685 & -56 & -79 & 76,688 & -53 & -75 \\
\hline Subbasin inflow & 6,302 & 6,304 & +2 & +3 & 6,304 & +2 & +3 \\
\hline Subbasin outflow & 20,444 & 20,432 & -12 & -17 & 20,427 & -17 & -24 \\
\hline Subbasin netflow & 14,142 & 14,128 & -14 & -20 & 14,123 & -19 & -26 \\
\hline
\end{tabular}

${ }^{1}$ Includes withdrawals from public supply, residential, and crop irrigation wells. 


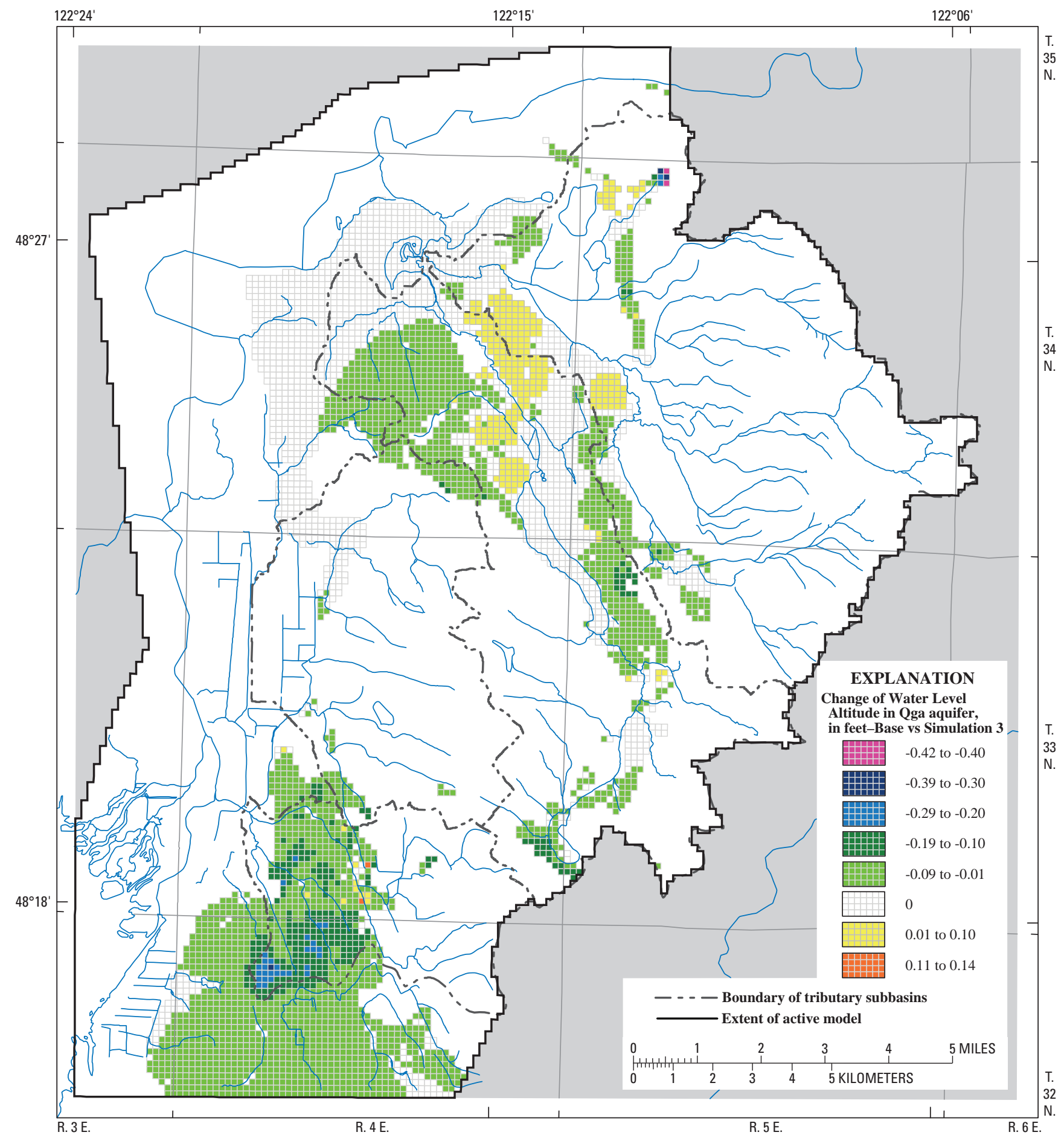

Figure 18. Simulated groundwater-level altitude change between the steady-state "base simulation" and simulation 3 , tributary subbasins and vicinity, lower Skagit River basin, Washington. 


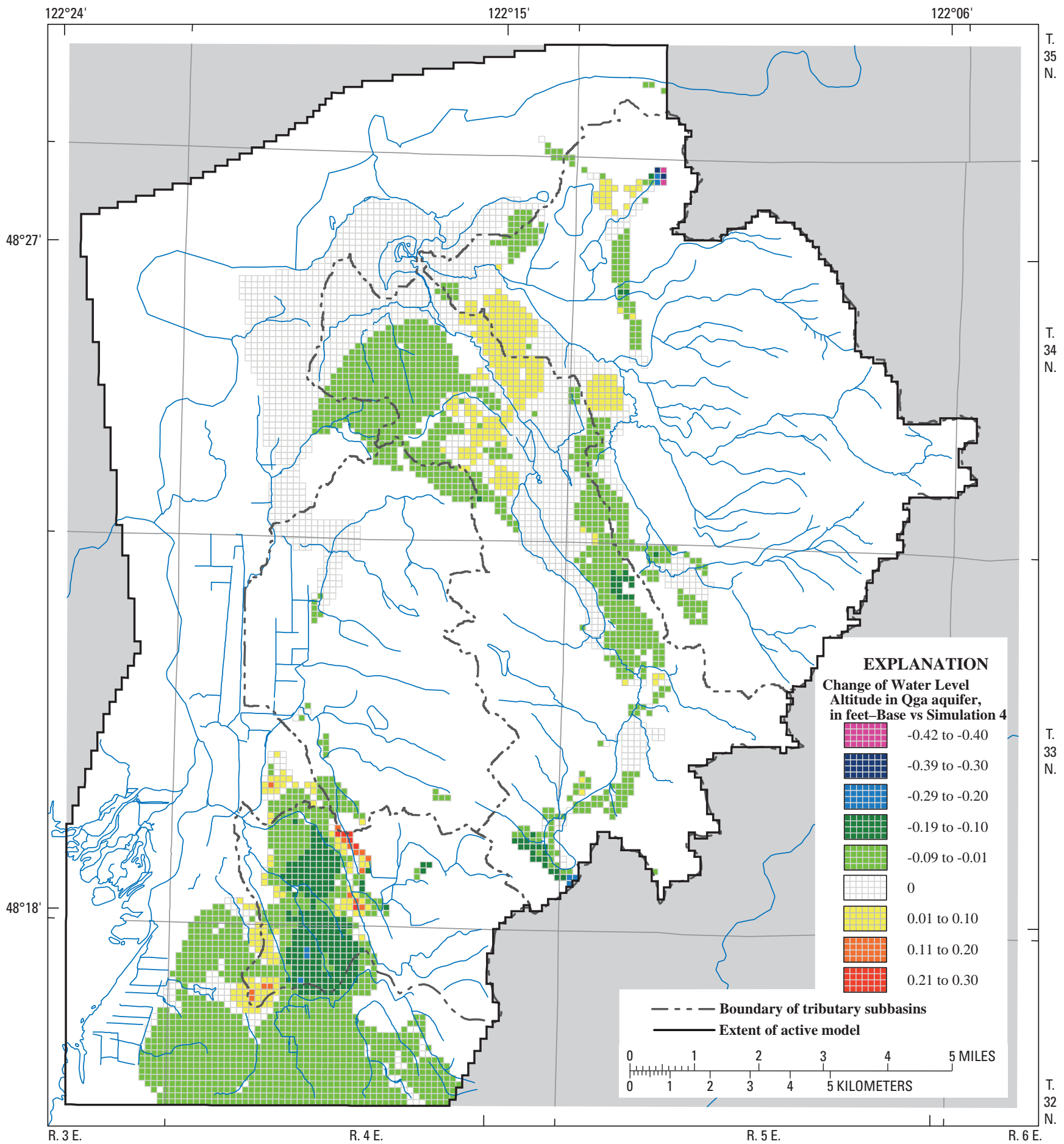

Figure 19. Simulated groundwater-level altitude change between the steady-state "base simulation" and simulation 4 , tributary subbasins and vicinity, lower Skagit River basin, Washington. 
Simulation 5. Decrease recharge by 20 percent throughout all four tributary subbasins to simulate drier conditions and maintain all other "base simulation" steady-state conditions. Compare simulation results to "base simulation" (table 13 and fig. 20).
Simulation 6. Decrease recharge by 20 percent throughout all four tributary subbasins and eliminate septic return flows (to simulate conversion from septic to sanitary sewer service); maintain all other "base simulation" steady-state conditions. Compare simulation results to "base simulation" (table 13 and fig. 21).

Table 13. Comparison of selected water budget components for the "base simulation" steady-state condition and simulations 5 and 6 , tributary subbasins, lower Skagit River basin, Washington.

[Subbasin net flow equals subbasin inflow minus subbasin outflow. Column entries may not add exactly due to rounding. A bbreviation: acre-ft/yr, acre-foot per year]

\begin{tabular}{|c|c|c|c|c|c|c|c|}
\hline $\begin{array}{l}\text { All tributary } \\
\text { subbasins }\end{array}$ & $\begin{array}{c}\text { Base simulation } \\
\text { (acre-ft/yr) }\end{array}$ & $\begin{array}{c}\text { Simulation } 5 \\
\text { (acre-ft/yr) }\end{array}$ & $\begin{array}{c}\text { Change } \\
\text { (acre-ft/yr) }\end{array}$ & $\begin{array}{l}\text { Percent of } \\
\text { change in } \\
\text { recharge }\end{array}$ & $\begin{array}{c}\text { Simulation } 6 \\
\text { (acre-ft/yr) }\end{array}$ & $\begin{array}{c}\text { Change } \\
\text { (acre-ft/yr) }\end{array}$ & $\begin{array}{l}\text { Percent of } \\
\text { change in } \\
\text { recharge }\end{array}$ \\
\hline \multicolumn{8}{|l|}{ Water budget component } \\
\hline Precipitation recharge & 92,636 & 74,109 & $-18,527$ & 100 & 74,109 & $-18,527$ & 98 \\
\hline Return flows & 445 & 445 & 0 & & 0 & -445 & 2 \\
\hline Withdrawals from wells ${ }^{1}$ & 2,201 & 2,201 & 0 & & 2,201 & 0 & \\
\hline Discharge to streams (net) & 76,741 & 58,719 & $-18,022$ & 97 & 58,285 & $-18,456$ & 97 \\
\hline Subbasin inflow & 6,302 & 5,975 & -327 & 2 & 5,936 & -366 & 2 \\
\hline Subbasin outflow & 20,444 & 19,612 & -832 & 4 & 19,561 & -883 & 5 \\
\hline Subbasin netflow & 14,142 & 13,637 & -505 & 3 & 13,625 & -517 & 3 \\
\hline
\end{tabular}

\footnotetext{
${ }^{1}$ Includes withdrawals from public supply, residential, and crop irrigation wells.
} 


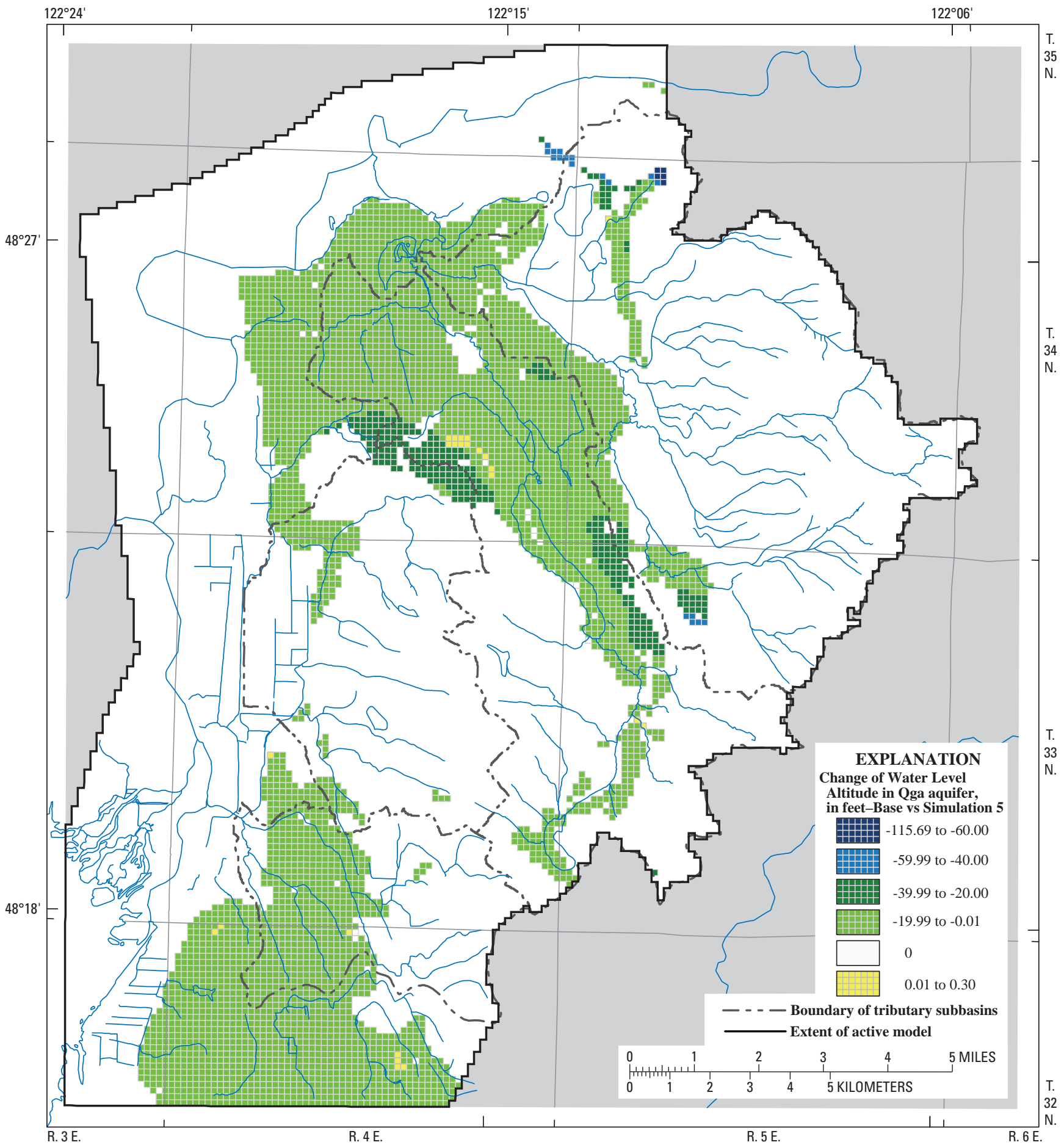

Figure 20. Simulated groundwater-level altitude change between the steady-state "base simulation" and simulation 5, tributary subbasins and vicinity, lower Skagit River basin, Washington. 


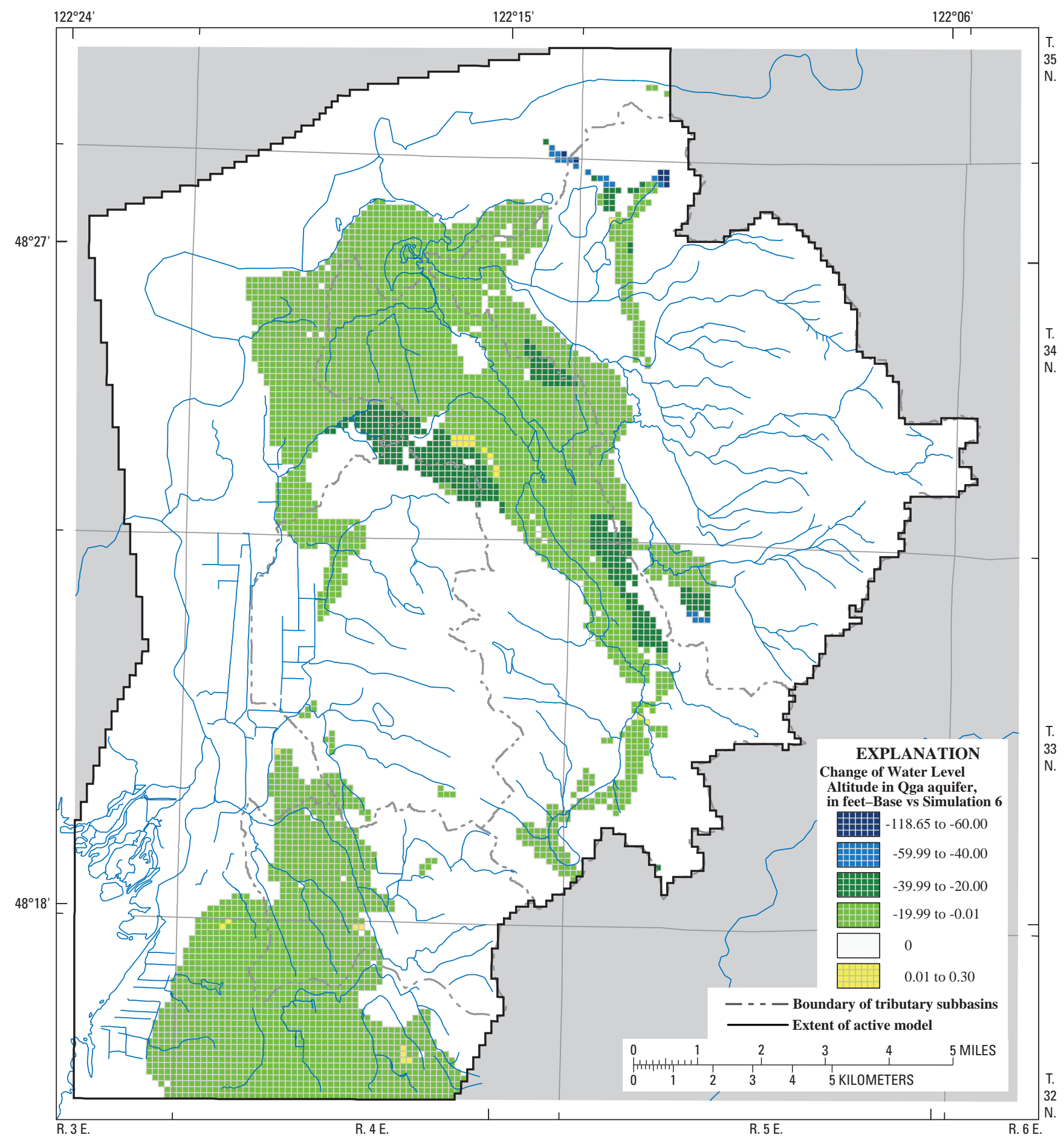

Figure 21. Simulated groundwater-level altitude change between the steady-state "base simulation" and simulation 6 , tributary subbasins and vicinity, lower Skagit River basin, Washington. 
Simulation 7. Increase current withdrawals by 50 percent along with corresponding increases in return flows in all residential wells throughout all four tributary subbasins under transient-state conditions for the transient simulation period (September 2006-September 2008). Compare simulation results to "base simulation" (table 14 and fig. 22).
Simulation 8. Increase current withdrawals by the same total amount in simulation 7 (with corresponding increases in return flows) but distribute that amount only in deeper wells throughout all four tributary subbasins under transient-state conditions for the transient simulation period (September 2006-September 2008). Compare simulation results to "base simulation" (table 14 and fig. 23).

Table 14. Comparison of selected water budget components for the simulation period (October 2006 to September 2008) for the "base simulation" transient model and simulations 7 and 8, tributary subbasins, lower Skagit River basin, Washington.

[Subbasin net flow equals subbasin inflow minus subbasin outflow. Column entries may not add exactly due to rounding. Abbreviation: acre-ft/yr, acre-foot per year]

\begin{tabular}{|c|c|c|c|c|c|c|c|}
\hline $\begin{array}{l}\text { All tributary } \\
\text { subbasins }\end{array}$ & $\begin{array}{c}\text { Base simulation } \\
\text { (acre-ft/yr) }\end{array}$ & $\begin{array}{c}\text { Simulation } 7 \\
\text { (acre-ft/yr) }\end{array}$ & $\begin{array}{c}\text { Change } \\
\text { (acre-ft/yr) }\end{array}$ & $\begin{array}{l}\text { Percent of } \\
\text { change in } \\
\text { consumptive } \\
\text { use }\end{array}$ & $\begin{array}{c}\text { Simulation } 8 \\
\text { (acre-ft/yr) }\end{array}$ & $\begin{array}{c}\text { Change } \\
\text { (acre-ft/yr) }\end{array}$ & $\begin{array}{c}\text { Percent of } \\
\text { change in } \\
\text { consumptive } \\
\text { use }\end{array}$ \\
\hline \multicolumn{8}{|l|}{ Water budget component } \\
\hline Precipitation recharge & 92,636 & 92,636 & 0 & & 92,636 & 0 & \\
\hline Return flows & 445 & 649 & 204 & & 649 & 204 & \\
\hline Change in consumptive use & & & +90 & 100 & & +90 & 100 \\
\hline From groundwater storage & 5,027 & 4,972 & -55 & 61 & 4,980 & -47 & 52 \\
\hline Discharge to streams (net) & 71,873 & 71,845 & -28 & 31 & 71,845 & -28 & 31 \\
\hline Subbasin inflow & 6,106 & 6,107 & +1 & 1 & 6,109 & +3 & 3 \\
\hline Subbasin outflow & 20,087 & 20,080 & -7 & -8 & 20,075 & -12 & -13 \\
\hline
\end{tabular}




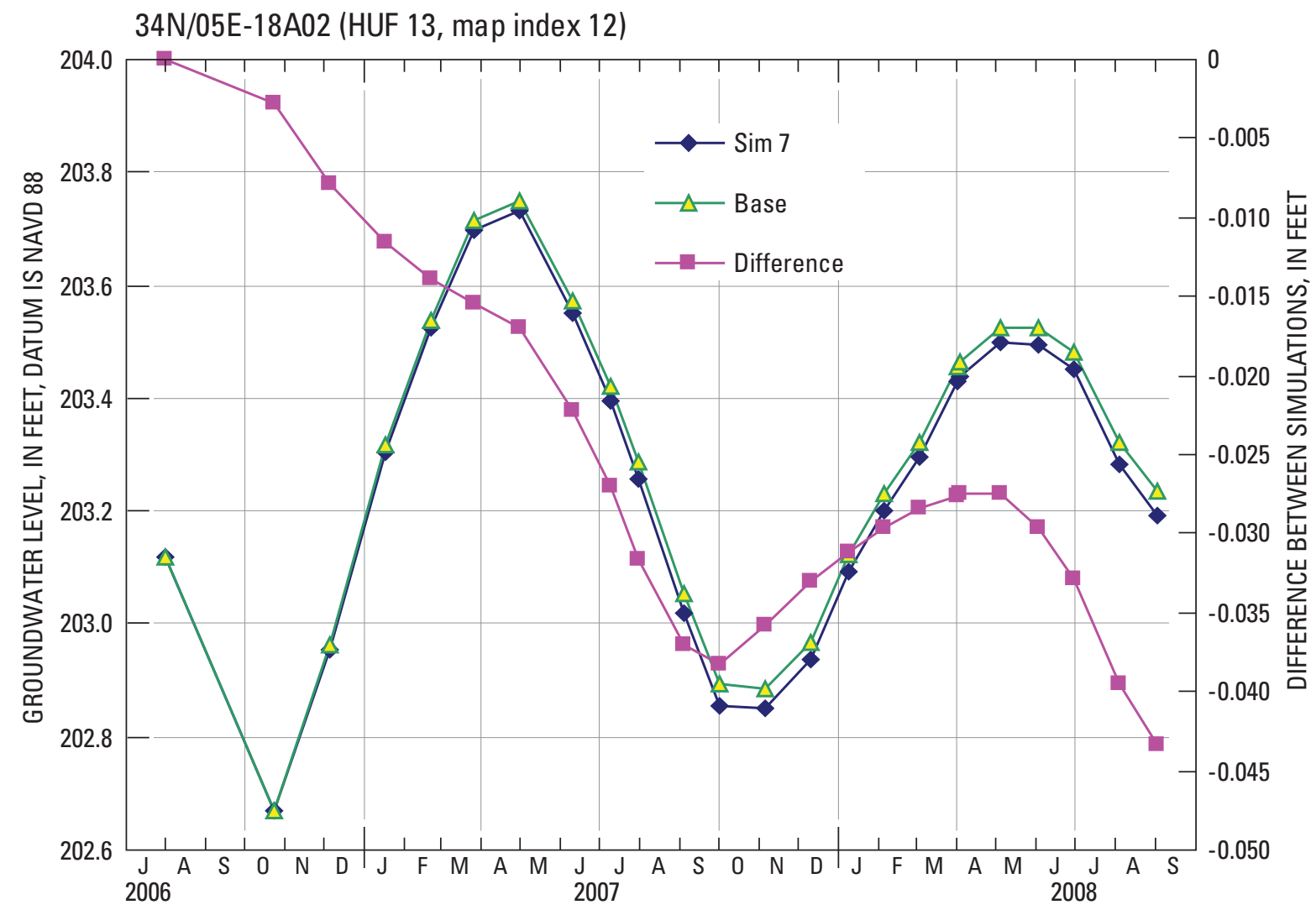

33N/04E-32D01 (HUF 7, map index 90)

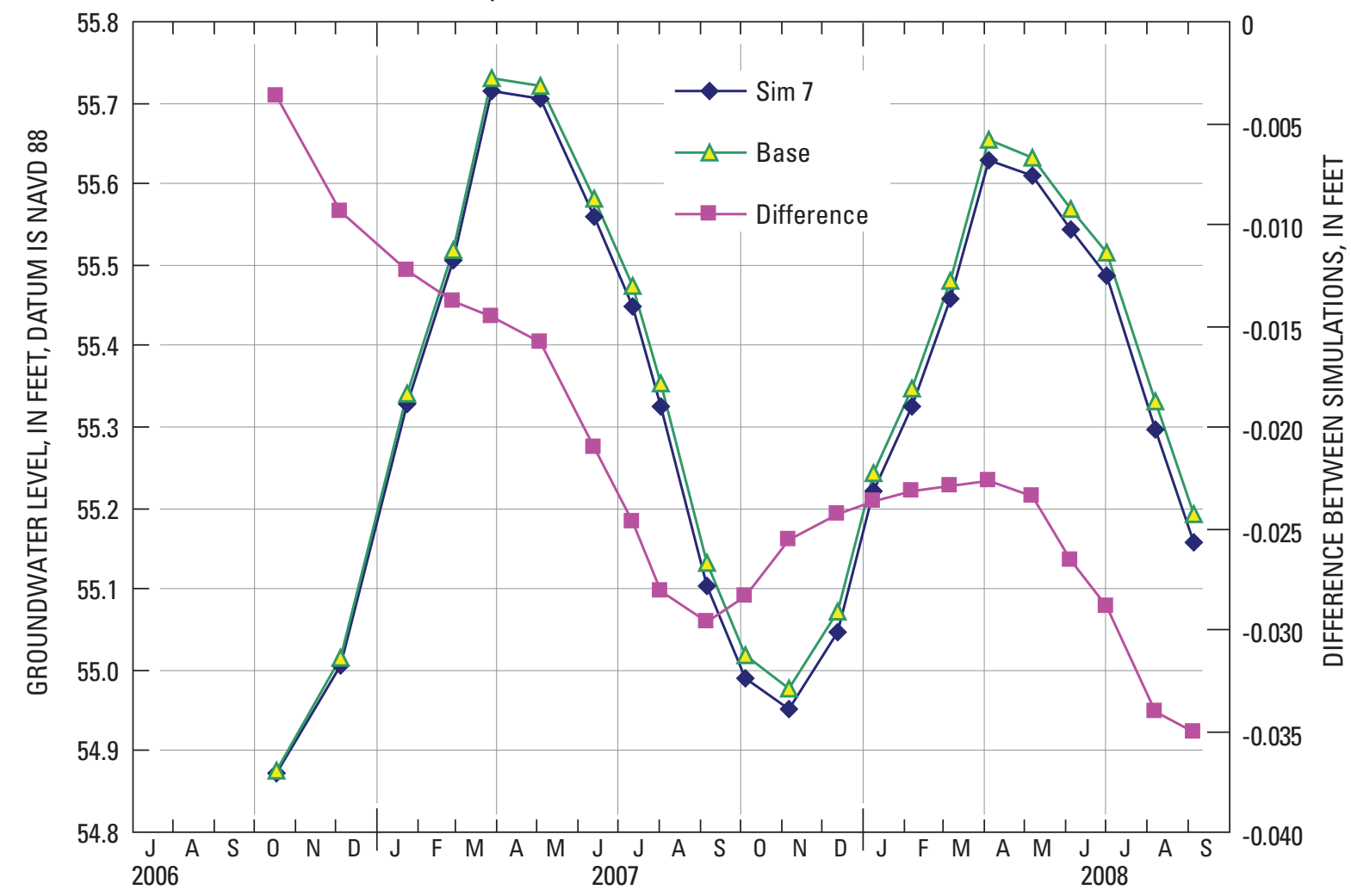

Figure 22. Simulated groundwater levels for transient "base simulation" and simulation 7 and difference, tributary subbasins and vicinity, lower Skagit River basin, Washington. 
34N/05E-18A02 (HUF 13, map index 12)

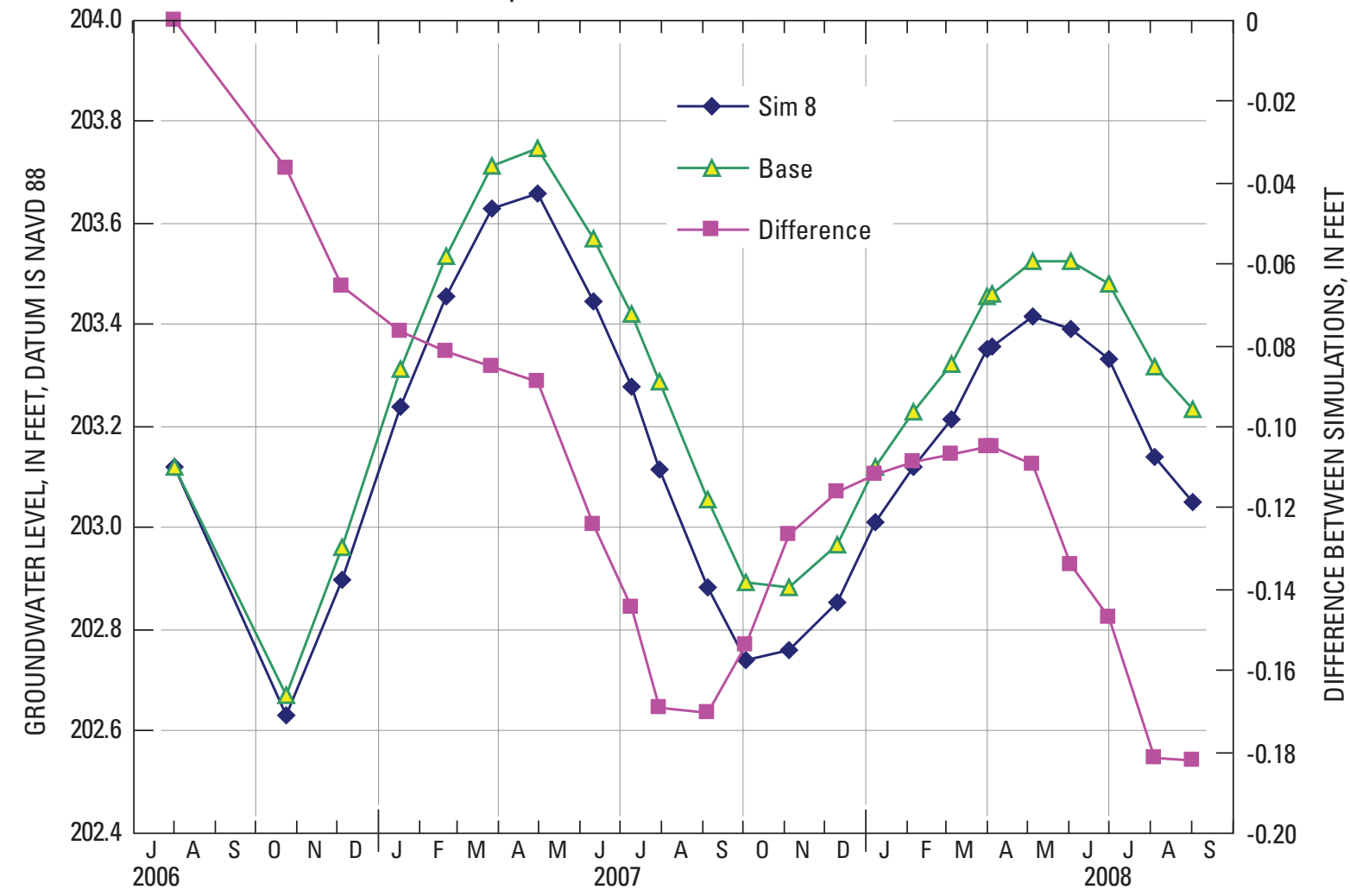

33N/04E-32D01 (HUF 7, map index 90)

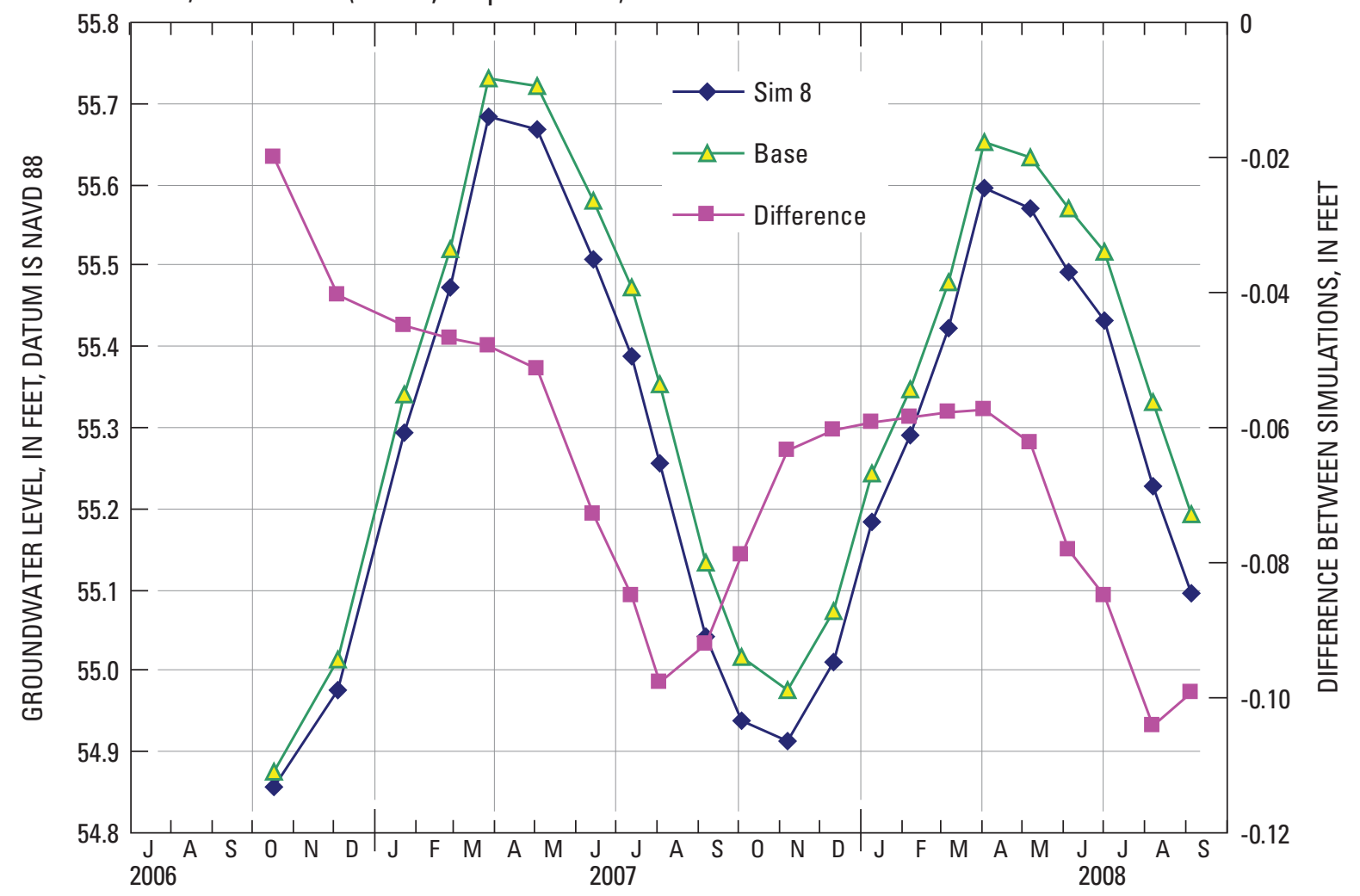

Figure 23. Simulated groundwater levels for transient "base simulation" and simulation 8 and difference, tributary subbasins and vicinity, lower Skagit River basin, Washington. 


\section{Numerical Simulation of the Groundwater-Flow System, Lower Skagit River, Washington}

Simulation 9. Increase current withdrawals by the same total annual amount in simulation 7 (with corresponding increases in return flows) but apply this withdrawal only during winter months (October-March) in all residential wells throughout all four tributary subbasins under transient-state conditions for the transient simulation period (September 2006-September 2008). Compare simulation results to "base simulation" (table 15 and fig. 24).

Table 15. Comparison of selected water budget components for the "base simulation" transient model and simulation 9, tributary subbasins, lower Skagit River basin, Washington.

[Subbasin net flow equals subbasin inflow minus subbasin outflow. Column entries may not add exactly due to rounding. A bbreviation: acre-ft/yr, acre-foot per year]

\begin{tabular}{lrrrr}
\hline $\begin{array}{c}\text { All tributary } \\
\text { subbasins }\end{array}$ & $\begin{array}{c}\text { Base simulation } \\
\text { (acre-ft/yr) }\end{array}$ & $\begin{array}{c}\text { Simulation } \mathbf{9} \\
\text { (acre-ft/yr) }\end{array}$ & $\begin{array}{c}\text { Change } \\
\text { (acre-ft/yr) }\end{array}$ & $\begin{array}{c}\text { Percent of } \\
\text { change in } \\
\text { consumptive } \\
\text { use }\end{array}$ \\
\hline Water budget component & & & & \\
$\quad$ Precipitation recharge & 92,636 & 92,636 & 0 & \\
$\quad$ Return flows & 445 & 639 & +194 & \\
$\quad$ Withdrawals from wells & 2,201 & 2,450 & +249 & \\
$\quad$ Change in consumptive use & & & +55 & 100 \\
From groundwater storage & 5,027 & 4,995 & -32 & 58 \\
Discharge to streams (net) & 71,873 & 71,854 & -19 & 34 \\
Subbasin Inflow & 6,106 & 6,107 & 1 & 2 \\
Subbasin Outflow & 20,087 & 20,082 & -5 & -9 \\
Subbasin Netflow & 13,981 & 13,975 & -6 & -10 \\
\hline
\end{tabular}


34N/05E-18A02 (HUF 13, map index 12)
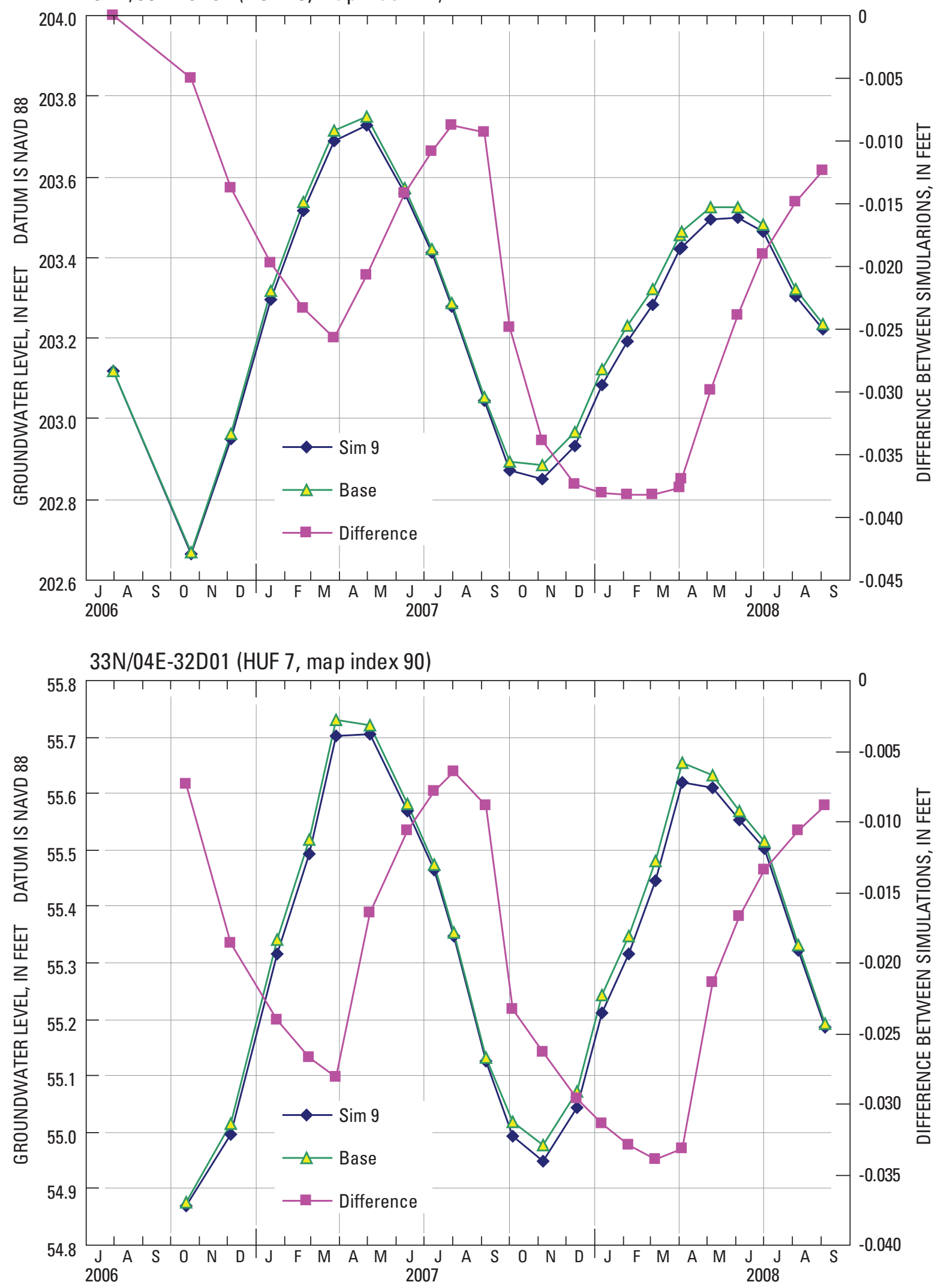

Figure 24. Simulated groundwater levels for transient "base simulation" and simulation 9 and difference, tributary subbasins and vicinity, lower Skagit River basin, Washington. 
The resulting change in flow components for simulation 1 (table 11) indicate that of the approximately 23 acre $\mathrm{ft} / \mathrm{yr}$ of increased consumptive withdrawals (pumpage in wells minus return flows) in the Nookachamps Creek subbasin, a majority (about 22 acre-ft/yr or 92 percent) comes from decreased discharge to streams, and only about 2 acre-ft/yr (9 percent) comes from decreased net flows to adjacent subbasins. Simulated water-level declines in the advance outwash aquifer (Qga, HUF unit 3) resulting from increased withdrawals typically ranged from about $0.2 \mathrm{ft}$ to less than $0.1 \mathrm{ft}$ with a maximum decline of $0.25 \mathrm{ft}$ (fig.16) A slight increase in simulated groundwater levels occurred in some areas, and may be the result of enhanced shallow groundwater recharge from increased return flows. Water-level declines are greatest in areas where the aquifer is present at higher altitudes and areas of greater relief. The aquifer was difficult to keep fully saturated even in the "base simulation" in these areas. Greater water-level declines in the aquifer also occurs in areas of higher well density.

The change in flow components for simulation 2 (table 11) indicates only a slight increase in the amount of consumptive withdrawal derived from subbasin net flow resulting from the distribution of withdrawals among deeper wells in the Nookachamps Creek subbasin. The amount of consumptive withdrawal derived from streamflow remained unchanged from simulation 1 and streamflow does not appear to be significantly influenced by the depth of withdrawals. This apparent lack of sensitivity may be due to increased groundwater discharge to streams through enhanced shallow groundwater recharge from increased return flows from deep withdrawals. Simulated water-level declines in the advance outwash aquifer (Qga, HUF unit 3) resulting from a deepening of increased withdrawals typically ranged from about $0.2 \mathrm{ft}$ to less than $0.1 \mathrm{ft}$ with a maximum decline of $0.3 \mathrm{ft}$ (fig. 17). A slight increase in simulated groundwater levels occurred in some areas. Water-level declines are greatest in areas where the aquifer is present at higher altitudes and areas of greater relief, and in areas of higher well density. A comparison of the simulated change in groundwater level between simulations 1 and 2 (figs. 16 and 17, respectively) suggests that the effect of deepening additional withdrawals was not of sufficient magnitude to produce a response in the advance outwash aquifer in the Nookachamps Creek subbasin. This lack of response may be the result of the relatively small amount of additional consumptive use associated with residential withdrawals (23 acre-ft/yr) compared to precipitation recharge (23,684 acre-ft/yr).

Simulations 3 and 4 apply increased withdrawals to all of the tributary subbasins (table 12). The resulting change in flow components for simulation 3 indicate that of the approximately $70 \mathrm{acre} \mathrm{ft} / \mathrm{yr}$ of increased consumptive withdrawals from the subbasin, a majority (about 56 acre-ft/yr or 79 percent) comes from decreased discharge to streams, and about $14 \mathrm{acre}-\mathrm{ft} / \mathrm{yr}$ (20 percent) comes from decreased net flows to the Skagit River valley. A deepening of withdrawals from the subbasins (simulation 4) results in a slight reduction in the amount of streamflow loss (about $53 \mathrm{acre}-\mathrm{ft} / \mathrm{yr}$ ) and a corresponding decrease in net flows to the Skagit River valley (about 19 acre-ft/yr). Simulated water-level declines in the advance outwash aquifer (Qga, HUF unit 3) typically ranged from about $0.3 \mathrm{ft}$ to less than $0.1 \mathrm{ft}$ with a maximum decline of about $0.4 \mathrm{ft}$ for simulations 3 and 4 (figs. 18 and 19). A comparison of the results of simulations 3 and 4 (figs. 18 and $\underline{19}$ ) suggest that the effect of deepening additional withdrawals in all tributary subbasins was sufficient to produce differences in the distribution of water-level change in the advance outwash aquifer in the southern part of the model area. Several areas of localized water-level increases (fig. 19) likely correlate with residential areas (fig. 6) and enhanced shallow groundwater recharge from increased return flows.

Simulations 5 and 6 reduce the amount of groundwater recharge (from precipitation, and precipitation and return flow, respectively) to all of the tributary subbasins (table 13). The resulting change in flow components for simulation 5 indicate that of the 18,527 acre $\mathrm{ft} / \mathrm{yr}$ reduction in groundwater recharge from precipitation a majority (about 18,022 acre-ft/ yr or 97 percent) comes from reduced discharge to streams, and 505 acre-ft/yr (3 percent) comes from decreased net flows to the Skagit River valley. Elimination of return flow (simulation 6) results in a slight increase in the amount of streamflow loss $(18,456$ acre-ft/yr) and a corresponding decrease in net flows to the Skagit River valley (about 517 acre-ft/yr). Simulated water level declines in the advance outwash aquifer (Qga, HUF unit 3) typically ranged from about $40 \mathrm{ft}$ to less than $1 \mathrm{ft}$ with a maximum decline of about $116 \mathrm{ft}$ for simulation 5 and about $119 \mathrm{ft}$ for simulation 6 (figs. 20 and 21). The effect of eliminating return flow on simulated groundwater levels is not of sufficient magnitude to be apparent for simulations 5 and 6, and this may be the result of the relatively small amount of return flows associated with residential withdrawals (445 acre-ft/yr) compared to precipitation recharge (74,109 acre-ft/yr).

Simulations 7, 8, and 9 were conducted using the transient model. Simulation 7 increases residential well withdrawals in all of the tributary subbasins for the transient simulation period (September 2006-September 2008). The resulting change in flow components for simulation 7 (table 14) indicate that of the approximately $90 \mathrm{acre} \mathrm{ft} / \mathrm{yr}$ of increased consumptive withdrawals from the subbasins over the transient simulation period, a majority (about 55 acre-ft/ yr or 61 percent) comes from decreased groundwater storage, about 28 acre-ft/yr (31 percent) comes from decreased discharge to streams, and about 8 acre-ft/yr (9 percent) comes from decreased net flows to the Skagit River valley. A deepening of withdrawals from the subbasins (simulation 8) results in a slight decrease in the amount of groundwater storage loss (about $47 \mathrm{acre}-\mathrm{ft} / \mathrm{yr}$ ), unchanged discharge to streams, and a decrease in net flows to the Skagit River valley (about 15 acre-ft/yr). 
Representative hydrographs of groundwater levels for the transient simulation period illustrate differences of less than $0.2 \mathrm{ft}$ between the "base simulation" and simulations 7 and 8 (figs. 22 and 23, respectively). Continually increasing water-level differences suggest the effects of withdrawals at mid and deep levels of the aquifer system did not stabilize during the simulation period and that a continued loss of groundwater storage is likely. The magnitude of water level differences are greater for both wells in simulation 8 , and are likely due to the deepening of withdrawals associated with this simulation.

Simulation 9 increases withdrawals only during the winter months (October-March) in all residential wells throughout all of the tributary subbasins under transient conditions for the transient simulation period. The resulting change in flow components for simulation 9 (table 15) indicate that of the approximately 55 acre $\mathrm{ft} / \mathrm{yr}$ of increased consumptive withdrawals from the subbasins over the transient simulation period, a majority (about 32 acre-ft/yr or 58 percent) comes from reduced groundwater storage, about 19 acre-ft/yr (34 percent) comes from reduced discharge to streams, and about 6 acre-ft/yr (10 percent) comes from decreased net flows to the Skagit River valley. A comparison of flow components between simulations 7 and 9 indicate that increasing only winter withdrawals reduces the amount of consumptive use derived from discharge to streams. A comparison of groundwater difference hydrographs between simulations 7 and 9 indicate that increasing only winter withdrawals delays by several months the timing of the greatest simulated impact of withdrawals on groundwater levels (figs. 22 and 24).

\section{Summary}

Recent population growth along the Interstate 5 corridor near Mount Vernon, Washington, has led to increased water use, with many new domestic wells serving residents in the lower portion of the Skagit River basin in areas not served by a regional public water system. Planning for future development in the lower basin, including the reservation of water for new domestic wells, requires identification of areas where withdrawals from existing and new wells could adversely impact stream flow in the Skagit River or its tributaries. A groundwater-flow model was developed by the U.S. Geological Survey to assist Skagit County and the Washington Department of Ecology in evaluating the effects of potential groundwater withdrawals and consumptive use on streamflows in tributary subbasins of the lower portion of the Skagit River basin.

The study area covers about 155 square miles along the Skagit River and its tributary subbasins (East Fork Nookachamps Creek, Nookachamps Creek, Carpenter Creek, Fisher Creek) in southwestern Skagit County and northwestern Snohomish County, Washington. The Skagit River occupies a large, relatively flat alluvial valley that extends across the northern and western margins of the study area, and is bounded to the south and east by upland and mountainous terrain. The alluvial valley and upland are underlain by unconsolidated deposits of glacial and inter-glacial origin. Bedrock underlies the alluvial valley and upland areas, and crops out throughout the mountainous terrain. Nine hydrogeologic units are recognized in the study area and form the basis of the groundwater-flow model.

Groundwater flow in tributary subbasins of the lower Skagit River and vicinity was simulated using the groundwater-flow model, MODFLOW-2000. The finite-difference model grid consists of 174 rows, 156 columns, and 15 layers. Each model cell has a horizontal dimension of 500 by $500 \mathrm{ft}$. The thickness of model layers varies throughout the model area. Boundary conditions representing inflow and outflow components are implemented using packages in MODFLOW-2000. The Recharge Package is used to simulate recharge from precipitation and water returned to the groundwater system through septic tanks or through irrigation return-flows. The Well Package is used to simulate withdrawals from wells. The River Package is used to simulate the exchange of water between subbasin streams and the aquifer system. Groundwater flow out of the model along the northwestern margin of the model domain in the Skagit Delta area was simulated with the General-Head Boundary Package. The Constant Head Boundary Package was used along part of the southwestern margin of the model domain to simulate groundwater discharge to Skagit Bay.

Available data were assembled and evaluated to construct and calibrate the model. Results of a hydrogeologic framework model constructed from analysis of drillers' logs from 296 wells were used to define the configuration of the aquifer system and confining units within the study area. The Hydrogeologic Unit Flow Package of MODFLOW-2000 was used to delineate 10 hydrogeologic units within the model that are spatially independent of the 15 model layers. Groundwater flow was simulated in unconsolidated deposits, sedimentary, and bedrock units in the tributary subbasins and adjacent portion of the Skagit River valley. Initial estimates and probable ranges of values for hydraulic properties used during model calibration were defined from data collected during previous studies in and adjacent to the study area.

Groundwater flow was simulated for both steady-state and transient conditions. The steady-state condition simulated average recharge, discharge, and water levels for the period, August 2006-September 2008. The transient simulation period, September 2006-September 2008, was divided into 24 monthly stress periods. Initial conditions for the transient model were developed from a 6-year "lead-in" period that used recorded precipitation and Skagit River levels, and extrapolations of other boundary conditions. During model calibration, variables were adjusted within probable ranges to minimize differences between measured and simulated groundwater levels and stream baseflows. The final calibrated steady-state and transient models have weighted mean residual of -10.1 and -2.2 feet, respectively (negative residuals indicate measured value is less than simulated). 
Simulated inflow to the model area was about 144,000 acre-feet per year (acre-ft/yr) (81 percent of simulated inflow) from precipitation and secondary recharge, and about 32,700 acre-ft/yr (19 percent of simulated inflow) from stream and lake leakage. Simulated outflow from the model primarily was through discharge to streams and lakes (about 166,500 acre-ft/yr; 94 percent of simulated outflow), and withdrawals from wells (about 9,800 acre-ft/yr; 6 percent of simulated outflow).

Model simulations were conducted to demonstrate model performance and to provide representative examples of how the model may be used to evaluate the effects of potential changes in groundwater withdrawals, consumptive use, and recharge on groundwater levels and tributary stream baseflows.

\section{Acknowledgments}

The authors wish to thank the many well owners in the study area who provided access to their wells during this study, and allowed the collection of data used in model development. Joe Dragovich and other staff of the Washington State Department of Natural Resources generously provided interpretive data that was crucial to the development of the hydrogeologic framework that forms the basis of the model. The authors gratefully acknowledge this significant contribution. The authors also wish to thank Skagit County and the Washington State Department of Ecology for providing assistance in the compilation of information used in model development.

\section{Selected References}

Anderman, E.R., and Hill, M.C., 2000, MODFLOW-2000, The U.S. Geological Survey modular ground-water model-Documentation of the Hydrogeologic-Unit Flow (HUF) Package: U.S. Geological Survey Open-File Report 00-342, 89 p., accessed May 1, 2009, at http://pubs. er.usgs.gov/usgspubs/ofr/ofr00342.

Bidlake, W.R., and Payne, K.L., 2001, Estimating recharge to ground water from precipitation at Naval Submarine Base Bangor and Vicinity, Kitsap County, Washington: U.S Geological Survey Water Resources Investigations Report 01-4110, 33 p.

Booth, D.B., 1994, Glaciofluvial infilling and scour of the Puget Lowland, Washington, during ice-sheet glaciation: Geology, v. 22, no. 8, p. 695-698
Doherty, J., 2005, PEST: Model-independent parameter estimation: Watermark Numerical Computing, Corinda, Australia, [variously paged].

Doherty, J., 2006, Addendum to PEST manual: Watermark Numerical Computing, Corinda, Australia, [variously paged].Dragovich, J. D., and DeOme, A.J., 2006, Geologic map of the McMurray 7.5-minute quadrangle, Skagit and Snohomish Counties, Washington: Washington Division of Geology and Earth Resources Geologic Mao GM-61, 18 p., 1 sheet, scale 1:24,000.

Dragovich, J. D., Pringle, P.T., and Walsh, T.J., 1994, Extent and geometry of the Mid-Holocene Osceola Mudflow in the Puget Lowland-implications for Holocene sedimentation and paleogeography: Washington State Department of Natural Resources, Washington Geology, v. 22, no. 3, p. 3-26.

Drost, B.W., Ely, D.M., and Lum II, W.E., 1999, Conceptual model and numerical simulation of the ground-water-flow system in the unconsolidated sediments of Thurston County, Washington: U.S. Geological Survey Water-Resources Investigations Report 99-4165, 254 p.

Fasser, E.T., and Julich, R.J., 2009, Hydrographs showing ground-water level changes for selected wells in the Lower Skagit River basin, Washington: U.S. Geological Survey Data Series 441.

Fetter, C.W., 1988, Applied hydrogeology: Columbus, Ohio, Merrill Publishing Company, 592 p.

Freeze, R.A., and Cherry, J.A., 1979, Groundwater: Englewood Cliffs, N.J., Prentice-Hall, 604 p.

GeoEngineers, 2003, Lower and upper Skagit watershed plan Samish River sub-basin, ground water hydrology evaluation: File no. 7291-001-00-1180, 175 p.

Harbaugh, A.W., Banta, E.R., Hill, M.C., and McDonald, M.G., 2000, MODFLOW-2000, the U.S. Geological Survey modular ground-water model-User guide to modularization concepts and the ground-water flow process: U.S. Geological Survey Open-File Report 00-92, 121 p., accessed May 1, 2009, at http://water.usgs.gov/nrp/ gwsoftware/modflow2000/ofr00-92.pdf.

Hsieh, P.A., Barber, M.E., Contor, B.A., Hossain, Md. A., Johnson, G.S., Jones, J.L., and Wylie, A.H., 2007, Groundwater flow model for the Spokane Valley - Rathdrum Prairie Aquifer, Spokane County, Washington, and Bonner and Kootenai Counties, Idaho: U.S. Geological Survey Scientific Investigations Report 2007-5044, 78 p. (Also available at http://pubs.usgs.gov/sir/2007/5044/.) 
Lane, R.C., 2009, Estimated water use in Washington, 2005: U.S. Geological Survey Scientific Investigations Report 2009-5128, 30 p.

National Oceanic and Atmospheric Administration, 2007, Climatological data, annual summary, Washington, 2007: Asheville, North Carolina, National Climatic Data Center, v.111, no. 13,30 p.

Oad, Ramchand, Lusk, Kevin, and Podmore, Terry, 1997, Consumptive use and return flows on urban lawn water use: Journal of Irrigation and Drainage Engineering, v. 123, issue 1, p. 62-69.

Oad, Ramchand, and DiSpigno, Michale, 1997, Water rights to return flow from urban landscape irrigation: Journal of Irrigation and Drainage Engineering, v. 123, issue 4, p. 293-299.

Pitz, C.F., and Garrigues, R.S., 2000, Summary of streamflow conditions, September 2000, Fisher Creek and Carpenter Creek Basin: Washington State Department of Ecology Publication no. 00-03-049, 44 p.

Sapik, D.B., Bortleson, G.C., Drost, B.W., Jones, M.A., and Prych, E.A., 1989, Ground-water resources and simulation of flow in aquifers containing freshwater and seawater, Island County, Washington: U.S. Geological Survey WaterResources Investigations Report 87-4182, 67p.

Savoca, M.E., Johnson, K.H., and Fasser, E.T., 2009b, Shallow groundwater movement in the Skagit River Delta Area, Skagit County, Washington: U.S. Geological Survey Scientific Investigations Report 2009-5208, 22 p.

Savoca. M.E., Johnson, K.H., Sumioka, S.S., Olsen, T.D., Fasser, E.T, and Huffman, R.L., 2009a, Hydrogeologic framework, groundwater movement, and water budget in tributary subbasins and vicinity, lower Skagit River basin, Skagit and Snohomish Counties, Washington: U.S. Geological Survey Scientific Investigations Report 20095270, 46 p.
Skagit County, 2008, Digital Data Warehouse: Geographic data for your mapping system: accessed March 1, 2008, at http://www.skagitcounty.net/Common/Asp/Default. asp? $\mathrm{d}=\mathrm{GIS} \& \mathrm{c}=$ General $\& \mathrm{p}=$ Digital $/ \mathrm{main} . \mathrm{htm}$.

Snohomish County, 2008, Maps \& GIS Data: accessed April 1, 2008, at http://www1.co.snohomish.wa.us/Departments/ PDS/Divisions/LR_Planning/Information/Maps/ mapsgisdata.htm.

Thomas, B.E., Wilkinson, J.M., and Embrey, S.S., 1997, The ground-water system and ground-water quality in western Snohomish County, Washington: U.S. Geological Survey Water-Resources Investigations Report 96-4312, 218 p., 9 plates.

U.S. Census Bureau, 2000, Census 2000 Data for the State of Washington, accessed April 1, 2008, at http://www.census. gov/census2000/states/wa.html.

U.S. Department of Agriculture, Natural Resources Conservation Service, 2007, Washington Irrigation Guide (WAIG), accessed March 1, 2009, at http://www.wa.nrcs. usda.gov/technical/ENG/irrigation guide/index.html.

van Heeswijk, Marijke, and Smith, D.T., 2002, Simulation of the ground-water flow system at Naval Submarine Base Bangor and vicinity, Kitsap County, Washington: U.S. Geological Survey Water-Resources Investigations Report 02-4261, 142 p. (Also available at http://pubs.usgs. gov/wri/wri024261/.)

Washington State Department of Agriculture, 2008, Agricultural Land Use: accessed January 1, 2009 at http:// agr.wa.gov/PESTFERT/NatResources/AgLandUse.aspx.

Washington State Department of Health, 2008, Division of Environmental Health, Office of Drinking Water: accessed March 1, 2008, at http://www4.doh.wa.gov/sentryinternet/ Intro.aspx.

Washington State Department of Ecology, 2010, Water Resources - Instream flows in Washington: accessed August 10, 2010, at http://www.ecy.wa.gov/programs/wr/ instream-flows/isfhm.html. 
Numerical Simulation of the Groundwater-Flow System, Lower Skagit River, Washington

This intentionally left blank. 
Publishing support provided by the U.S. Geological Survey

Publishing Network, Tacoma Publishing Service Center

For more information concerning the research in this report, contact the

Director, Washington Water Science Center

U.S. Geological Survey

930 Broadway, Suite 300

Tacoma, Washington 98402

http://wa.water.usgs.gov 

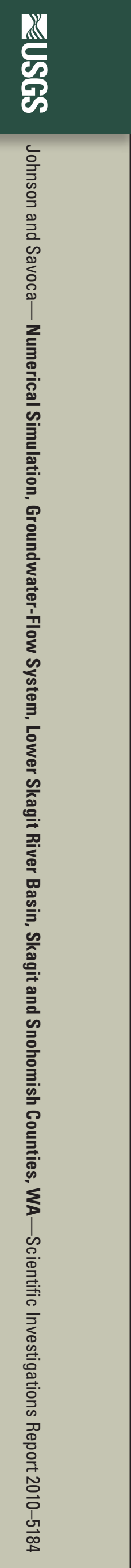